\title{
La muralla almohade de Cáceres: aspectos constructivos, formales y funcionales
}

\author{
Samuel Márquez Bueno * \\ Pedro Gurriarán Daza ***
}

\begin{abstract}
RESUMEN
La investigación que presentamos en las siguientes líneas tiene por objeto realizar un estudio exhaustivo de las estructuras almohades que constituyen la muralla de Cáceres. Dada la lamentable ausencia de referentes arqueológicos y cronísticos, nos centraremos en la sistemática definición arquitectónica y edilicia de los importantes restos conservados a través de sus aspectos constructivos, formales y funcionales. Además, se estudiará un epígrafe inédito de indudable raigambre almohade aún presente en la Torre de los Pozos, el cual, junto a otros elementos simbólicos asociados al mismo, representa uno de los escasos testimonios propagandísticos estudiados en obras militares andalusíes promovidas por las autoridades muminíes. Por último, incidiremos sobre la cronología de la cerca cacereña, situando esta gran actuación edilicia en tiempos del califa Ya'cub al-Mansur tras la campaña extremeña de 1196.
\end{abstract}

PALABRAS CLAVE: Almohade. Cáceres. Murallas. Albarrana. Tapial. Epigrafía

\section{INTRODUCCIÓN}

El presente trabajo trata sobre la muralla almohade de Cáceres, uno de los recintos urbanos andalusíes de época almohade más sobresalientes que conservamos en nuestro país; tal importancia se debe no sólo a la extraordinaria permanencia de gran parte del vasto perímetro de esta cerca construida por los alarifes muminíes a fines del siglo XII, sino también

\begin{abstract}
The present research is mainly concerned with the development of an exhaustive study on the Almohade wall structures in Cáceres. Due to a regrettable carence of both archaelogical and chronicle findings it is our intention to focus on the systematic architectural and building definition of the remarkable relics which have been preserved by means of its constructive, formal and functional characteristics. Furthermore, a study on an unknown inscription from an unquestionable Almohade procedence and still noticeable in the Torre de los Pozos, is also provided in this work. This inscription, along with other symbolic elements associated with it, represents one of the scarce propaganda testimonies analysed in militar Andalusian construction which were fostered by the Almohade authorities in charge at that time. Finally, a particular emphasis will be placed on the chronology of the wall, dating this great constructive work in Califa Ya'cub al-Mansur's times, after his militar campaign in Extremadura in 1196
\end{abstract}

KEY WORDS: Almohade. Cáceres. Wall. Albarrana (External tower). Tapial (Wall made of sand). Epigraphy

a la correcta identificación y lectura de sus elementos poliorcéticos de defensa y flanqueo con independencia de los posteriores procesos de evolución y transformación urbana. Es decir, la cantidad y, sobre todo, la relativa calidad de las construcciones militares cacereñas, sorprendentemente indemnes ante el urbanismo moderno y contemporáneo, nos sirven como indiscutibles elementos de estudio a la hora de definir de forma sucinta el carácter

\footnotetext{
* Yamur. Arquitectura y Arqueología S.L.

*** Instituto de Estudios Campogibraltareños. Yamur. Arquitectura y Arqueología S.L.
} 
como fortificación de este interesante recinto y su relación con el resto de la prolija producción defensiva almohade.

Tenemos claro que el correcto conocimiento y comprensión de toda construcción militar andalusí ha de partir de la indiscutible relación que se establece entre tres campos distintos: histórico, a través del estudio de las fuentes, arquitectónico e, indisolublemente relacionado con este último, arqueológico, en tanto estudio de estratigrafías murales y de subsuelo, estableciendo su secuencia diacrónica. No obstante, este método de aproximación al estudio del fenómeno poliorcético en al-Andalus no agota por sí mismo el análisis de un elemento específico, pues, en ocasiones, el concurso de epigrafistas y otros especialistas será indispensable, pero servirá como norma general para establecer ciertas conclusiones más o menos definitivas sobre el objeto de estudio cuando se relacionan entre sí las que arroja cada campo de forma individual. Pues bien, y sin detenernos demasiado en prioridades y peculiaridades de este método (generalmente aceptado por la mayoría de la comunidad científica), conviene que realicemos una serie de puntualizaciones a la hora de aplicarlo en el caso que nos ocupa. Efectivamente, cuando tratamos sobre la muralla que hoy se conserva en Cáceres, es necesario apuntar cómo dos de estos pilares indispensables casi no aportarán dato alguno, al ser prácticamente inexistentes. A la llamativa e injustificable ausencia de trabajos arqueológicos relacionados con la muralla, y, por añadidura, sobre el resto del espacio intramuros, se une un inquietante silencio textual al referirse a esta ciudad en el período que nos ocupa (siglo XII), solo roto por algunos datos oscuros en torno a asedios y conquistas. Además, no consta ninguna mención a la construcción de defensas en Cáceres por parte de cronistas musulmanes o incluso cristianos.
Esta singular falta de información, que marcará cualquier tipo de estudio sobre las estructuras hoy día conservadas, ya ha sido señalada por aquellos investigadores que se han aproximado de forma científica a las mismas. Así, desde el pionero estudio de Leopoldo Torres Balbás, hasta las recientes publicaciones de Fernando Valdés Fernández, en todas ellas se hace mención explícita a la tara documental que caracteriza a esta fortificación extremeña !. En nuestro caso, obviamente, vamos a disponer de idénticos mimbres que el resto a la hora de confeccionar un trabajo científico sobre la muralla de Cáceres. Es decir, la ausencia de datos cronísticos y arqueológicos nos obliga a centrar nuestros esfuerzos en la definición arquitectónica de las estructuras existentes, aun a sabiendas de lo delicado que es abordar la cuestión a través de un único enfoque. De este modo, trataremos de plantear un esquema metodológico de análisis adecuado al objeto en cuestión, que nos permita obtener una correcta y adecuada definición de las construcciones estudiadas mediante sus aspectos constructivos, formales y funcionales.

El estudio edilicio de una estructura o edificio es el resultado tanto de la misma labor arqueológica transplantada y continuada en los estratos parietales como del conocimiento de la historia de las técnicas constructivas en tanto disciplina arquitectónica; su carácter como elemento de datación será fundamental dentro de este enfoque analítico, aunque nunca será concluyente (sabemos que la técnica del tapial es característica del mundo almohade, pero sólo por ella no podemos establecer datas al existir en otros períodos; necesitamos otros elementos definitorios). Los puntos de vista tanto formales como funcionales irán íntimamente relacionados, y son, quizás, los aspectos más arquitectónicos, o si se prefiere, menos arqueológicos dentro del análisis. Esto es así ya

\footnotetext{
I Así se pronunciaba ya L. TORRES BALBÁS, "Cáceres y su cerca almohade", al-Andalus, XIII, 2, Madrid-Granada 1948 , pp. 446 a 472. En la actualidad destaquemos sobre todo a F. VALDÉS FERNÁNDEZ, "La fortificación islámica en Extremadura: Resultados provisionales de los trabajos en las alcazabas de Mérida, Badajoz y Trujillo y en la cerca urbana de Cáceres", Extremadura Arqueológica, II, Mérida-Cáceres, I99I, pp. 547 a 557; así como en "El urbanismo islámico de la Extremadura leonesa: Cuatro pautas de desarrollo", Genèse de la ville islamique en al-Andalus et au Magreb Occidental, Madrid, 1998, pp. I72 a I79; "Urbanismo islámico en la Raya de Portugal", Jornadas de cultura hispano-portuguesa, Madrid, 1999, pp. 229 a 254.
} 
que tratan sobre cómo los constructores de cada época van adaptando la forma de sus estructuras ante similares funciones, o, incluso, cómo idénticas formas responden a fines distintos, sobrepasando generalmente la propia noción de arquitectura para adentrarse muchas veces en terrenos socio-políticos ${ }^{2}$. Los aspectos formales han sido bastante recurridos para establecer cronologías, aunque sus valores no dejan de ser más o menos fiables; véase si no el filón de las torres albarranas, puertas en recodo y tantos otros elementos, cuyo valor cronológico se ha ido adelantando progresivamente desde los siglos XI-XII hasta período omeya ${ }^{3}$. Por el contrario, mientras las morfologías suelen responder a menudo a criterios generalmente sincrónicos, los aspectos funcionales tienden a manifestarse de modo diacrónico resolviendo formalmente necesidades parecidas que se repiten tanto en el espacio como en el tiempo. En definitiva, todas estas ramificaciones de la analítica arquitectónica han de partir, por su propio carácter, y de forma necesaria, del estudio comparativo con aquellas otras construcciones ya datadas previamente de forma más o menos indiscutible, siempre y cuando, y tal es nuestro caso, se prescinda por su ausencia de la información arqueológica y cronística.

Así, y con estas premisas básicas, proponemos una aproximación exhaustiva sobre la muralla almohade de Cáceres, incidiendo necesariamente en su conocimiento como realidad arquitectónica dentro del conjunto de la arquitectura militar andalusí en general, y almohade en particular. Para ello nos centraremos en sus aspectos constructivos y morfológicos, donde esa "forma" particular que es la torre albarrana presentará un protagonismo especial, dado su elevado número, tanto que servirá para defi- nir por sí misma el carácter del recinto completo. Además de realizar un sistemático estudio arquitectónico, aprovecharemos este trabajo para presentar un testimonio epigráfico inédito, aún in situ en una de las torres de la cerca cacereña, cuya evidente filiación almohade constituye una de las escasas referencias indiscutibles, más allá de aspectos formales y constructivos, de la autoría muminí de estas estructuras defensivas. Abrimos así una nueva vía de estudio en torno a uno de los más importantes recintos defensivos construido bajo la égida de los califas almohades en al-Andalus, introduciendo una nueva voz dentro de ese tradicional silencio que la ausencia de fuentes e intervenciones arqueológicas había tejido a su alrededor.

\section{ASPECTOS FORMALES $Y$ FUNCIONALES: DEFINICIÓN TIPOLÓGICA Y MORFOLÓGICA}

\section{Situación y organización en planta}

El recinto amurallado de Cáceres está situado sobre una suave loma que forma parte de la Sierra de la Mosca, la cual se encuentra a una veintena de kilómetros a mediodía del río Tajo ${ }^{4}$. Alcanza esta elevación una cota máxima en torno a la plaza de San Mateo de 460.27 m.s.n.m.; A partir de dicho punto el terreno cae con una pendiente poco pronunciada, excepto a levante, donde el desnivel se manifiesta más pronunciado según nos aproximamos al arroyo del Marco, cuyo lecho está a 406.00 m.s.n.m.. Divide este promontorio donde se alza la cerca cacereña, un afloramiento de cuarcita silúrica según una alineación que discurre entre la torre de los Pozos y la torre del

2 Por ejemplo, la propia puerta meridional del castillo de Gormaz, monumental arco del triunfo trazado siguiendo finos cánones califales, traslada un motivo eminentemente civil a una obra militar respondiendo a ideas políticas de propaganda del triunfante estado islámico; en este caso, el prestigio cordobés adopta como características formas que nacieron para satisfacer simples necesidades arquitectónicas.

3 Véase como ejemplo lo referido en J. ZOZAYA, "FFortificaciones tempranas?", Actas del I Congreso de Castellología Ibérica, Palencia, 1994, pp. 71 a 146.

4 Esta sierra constituye una pequeña elevación sobre la penillanura cacereña. De forma oval (con 15 Km de eje mayor y 7.5 Km. De eje menor) presenta dirección SE-NO y una altura máxima de 664 m.s.n.m., elevándose unos 200 m sobre la altura media de la citada penillanura. Refieren esta cuestión A. MORA PEÑA et alii, Cáceres, paseos y rutas naturalistas por la sierra de la Mosca, Cáceres, 1997, p. 9. 
postigo de Santa Ana. Hacia el norte el terreno se configura con pizarras silur-devónicas, mientras que hacia el sur la formación geológica dominante será de pizarras ordovícicas ${ }^{5}$. Las estructuras militares promovidas por las autoridades almohades forman en su conjunto un recinto trapezoidal tendiendo al rectángulo, orientado en su eje mayor de norte a sur, donde se alcanzan $440.00 \mathrm{~m}$ de longitud máxima. Las coordenadas generales U.T.M. de este recinto están comprendidas entre $X$, 726 100.7886-726465.1346; Y, 4373067.7300 -4372647.8500. El perímetro construido poseería en su origen aproximadamente 1174.70 m, mientras que la superficie cercada total rondaría las $8.256 \mathrm{Ha}^{6}{ }^{\text {(Lám. I). }}$

En su estado definitivo el recinto debió estar jalonado, aproximadamente, por unas veinte torres exentas o albarranas, de las que se conservan dieciséis en mejor o peor estado (Fig. I). También existía una cantidad indeterminada de cubos nunca superior al número de albarranas, pues solían disponerse intercalados entre ellas, de los que restan siete. De los cuatro flancos de la fortificación, aquel que mantiene su morfología almohade con menos alteraciones es el de poniente, comprendido entre una exenta octogonal en el extremo suroccidental y otra albarrana también, pero de forma desconocida, en el ángulo noroeste. Este tramo consta de otras cinco exentas cuadrangulares alternadas, en puntos determinados, con cubos de la misma naturaleza. Aquellas guardan una separación bastante regular que, medida en su proyección ortogonal, oscila entre 60 y $80 \mathrm{~m}$. Esta circunstancia apoya una posible hipótesis que defendería la inexistencia de un acceso impor- tante al recinto en todo este flanco, que, por otra parte, es el más vulnerable dado lo suave del desnivel del terreno, especialmente hacia el norte. Por otra parte, se justificaría así la situación en esta zona de las mayores exentas cuadrangulares de todo el recinto: Yerba y Bujaco. En los restantes frentes sí se abrirían puertas, de las cuales sólo se conserva la conocida como Arco del Cristo.

Hemos de tener en cuenta que este recinto es mencionado en las fuentes islámicas de distinto periodo indistintamente como madina o como hisn ${ }^{8}$, lo cual debe hacer plantearnos la cuestión acerca del verdadero carácter de este asentamiento. Sin embargo, y con independencia de precisiones etimológicas que se escapan al objetivo principal de este estudio, sí resulta evidente que las mayores peculiaridades de esta plaza residen en lo vasto de su extensión en fase almohade, acorde a lo visto en numerosas mudun, $y$, sin embargo, en su al menos aparente falta de importancia administrativa y cultural. Resulta sugerente, y pensamos que acertada, la hipótesis de Fernando Valdés que relaciona Cáceres con una ciudad campamento ${ }^{9}$, para lo cual recurre al conocido testimonio de al-Idrisi donde se refiere cómo en ella "se reunían allí para ir a robar y saquear el país de los cristianos" 10 . Aunque la cita del geógrafo ceutí se refiere a un recinto anterior al almohade objeto de estudio, ya que se encuadra en la primera mitad del siglo XII, pensamos que el concepto de gran recinto para acantonar tropas se mantiene en la última y definitiva fase constructiva islámica, definiendo la importancia militar del enclave. Al igual que opina Fernando Valdés, aquí encontraría-

5 Véase croquis en ibidem, 1997, pp. 9 y 11.

6 Otros autores arrojan otras cifras, como las 8.67 Ha que ofrece C. MAZZOLI-GUINTARD, Villes d'al-Andalus. L'Espagne et le Portugal à l'époque musulmane (VIIle- XVe siècles), Rennes, 1996, p. 328. Considerando la superficie intramuros referida, y comparándola con las de otros recintos urbanos, se comprueba cómo ésta es parecida a la estudiada en Guadix $(8.30 \mathrm{Ha})$, Silves $(9.20 \mathrm{Ha})$ o $\operatorname{Vascos}(8.00 \mathrm{Ha})$.

7 Esta opinión es compartida de forma explíita por G. RODRÍGUEZ CEREZO, "La muralla musulmana de Cáceres", Alcántara, Nº 15, 1988, p. 98.

8 C. Mazzoli-Guintard refiere seis citas en las fuentes musulmanas sobre Cáceres, en tres de las cuales consta como madina, mientras que en otras dos aparece como hisn; C. Mazzoli-Guintard Op. Cit., 1996, p. 316.

9 F. VALDÉS FERNÁNDEZ, Op. Cit., 1998, pp. 172 y 173.

10 Consúltese, AL-IDRISI, Description de I'Afrique et de I'Espagne, Trad. R. Dozy y M. J. de Goeje, Amsterdam, 1969, p. 227. 
mos el típico esquema tripartito que diferencia gran albacar vacío para tropas, alcazaba y espacio urbano propiamente dicho, en este caso siguiendo el modelo de organización urbana que Christine Mazzoli-Guintard define como "ciudad de colina" "'. Pensamos que la reforma almohade se identificaría con ese proyecto promovido por las autoridades califales de crear amplios recintos donde albergar grandes contingentes militares, segregados de la población local, para acometer las periódicas campañas contra tierras cristianas ${ }^{12}$. Ejemplos coetáneos los tenemos, por ejemplo, en Tarifa, donde se construye un nuevo recinto defensivo que casi duplica el anterior ${ }^{13}$, y en Sevi$\|$ a, ciudad en la que se establecen distintas alcazabas articuladas en torno al antiguo alcázar taifa, separadas de la madina andalusí. Posiblemente responda a este concepto de campamento la enorme ampliación que sufre Jerez en este periodo.

De este modo, es posible atribuir a Cáceres esta hipotética estructura organizada alrededor de una alcazaba que, extrañamente, vendría a ocupar una zona central e interior, pero que se corresponde con la rasante más elevada de toda la loma ${ }^{14}$. Aunque es seguro que tendría comunicación directa con el exterior, su ubicación viene a testimoniar tal vez la fosilización de la alcazaba prealmohade dentro de una nueva distribución urbana. Alrededor de la misma se articularían tanto el espacio reservado a la población como un recinto vacío o albacar y separados de manera estricta. El testimonio arqueológico de esta separación lo poseemos en el muro que se prolonga a partir del paso albarrano de la torre del Horno y que atraviesa el lienzo de muralla ortogonalmente interrumpiendo el paso del adarve (Fig. 2). Aquel elemento adquiriría una importancia determinante, pues actuaría a modo de muro diafragma impidiendo la comunicación entre un espacio y otro, al no existir jerarquización entre ambos.

\section{Accesos. Puertas y postigos}

\section{Puerta de Mérida}

Así se designa a la desaparecida puerta que se abría en el frente meridional del recinto, de la que no es visible ningún vestigio arqueológico. Sin embargo, la documentación histórica nos atestigua su existencia. Además, disponemos de testimonios que nos aportan algunos datos sobre su construcción, como son su fábrica de cantería y la existencia de una torrecilla adyacente al arco de su entrada ${ }^{15}$. Se encontraba situada entre dos torres albarranas que la protegían, la supuesta torre de la puerta de Mérida y la también demolida torre de Mari Lucas ${ }^{16}$.

I I Se caracteriza este esquema porque "la ville occupe le sommet et les flancs d'une colline aux pentes douces; la muraille, court sur I'ensemble du périmètre urbain. Le point le plus élevé du site porte le plus souvent le réduit fortifié [...]”; C. MAZZOLI-GUINTARD, Op. Cit., 1996, pp. 52 y 53.

12 Apunta esta cuestión, M. ACIÉN ALMANSA, "La fortificación en al-Andalus", Archeologia Medievale, XXII, 1995, p. 29.

13 Véase lo referido en A. TORREMOCHA SILVA y A. J. SÁEZ RODRÍGUEZ, "Fortificaciones islámicas en la orilla norte del Estrecho", Actas I Congreso Internacional Fortificaciones en al-Andalus (Algeciras, noviembre-diciembre, 1996), Algeciras, I998, pp. I89 y 198. Igualmente se cita esta cuestión en P. GURRIARÁN DAZA y A. J. SÁEZ RODRÍGUEZ, "Tapial o fábricas encofradas en recintos urbanos andalusíes", en Actas del II Congreso Internacional "La Ciudad en al-Andalus y el Magreb", noviembre 1999, Granada, 2002, p. 610

14 Ya se menciona una ubicación aproximada del alcázar en L. TORRES BALBÁS, Op. Cit., 1948, pp. 466 a 472 , donde se relaciona el conocido aljibe de las Veletas con esta construcción. Además, para restituir una posible ubicación de la alcazaba cacereña contamos con dos elementos principalmente: un basamento de sillares atizonados en el palacio de las Cigüeñas identificado en la Cuesta de la Compañía, que Fernando Valdés refiere como perteneciente a una torre, F. VALDÉS FERNÁNDEZ, Op. Cit., 1998, p. I76. Por otra parte disponemos del testimonio que menciona la erección del convento de San Pablo "sobre parte de las ruinas del alcázar", véase, M. A. ORTÍ BELMONTE, Guías Artísticas de España. Cáceres y su provincia, Barcelona, I954, p. 23.

I5 Estos datos los obtenemos a partir del testimonio acerca de la conveniencia de su demolición por un particular en I75।; consúltese, Archivo Municipal de Cáceres, Libro de Acuerdos, I75 I- |754, I7 de febrero de 175।.

I6 Refiere esta cuestión, M. M. LOZANO BARTOLOZZI, El desarrollo urbanístico de Cáceres, Cáceres, I980, p. 7I. Respecto a la supuesta torre de la puerta de Mérida, véase F. J. SELLERS BERMEJO et alii, Las torres ocultas del recinto amurallado de Cáceres, Cáceres, 1999, apartado 7.2. 


\section{Arco del Cristo}

Se conoce con este nombre la única puerta conservada del recinto defensivo cacereño anterior a época moderna, aunque también se la refiera como puerta del Río o de Fuente Concejo 17. Aparece abierta de forma oblicua en el frente de levante de la cerca, flanqueada en la actualidad solo por la torre del Río.

Este acceso, de tipo directo, se resuelve mediante un profundo corredor cubierto por bóveda de medio cañón cuyo frente exterior se constituye por un arco de medio punto que apoya en simples mochetas. El arco del otro extremo arranca más alto que el anterior, adaptándose al desnivel del pasadizo. No se aprecia resto alguno de rastrillo ni ningún otro tipo de defensa vertical. Para su construcción fueron empleados sillares graníticos que rondan los $50 \mathrm{~cm}$ de altura (Lám. 2).

Se puede inferir un trazado romano para la estructura general de la puerta, siguiendo lo visto en las puertas de San Pedro y de la Guía de Coria ${ }^{18}$, aunque éstas sean más evolucionadas por la presencia de rastrillo. Sin embargo, el estudio general del acceso no descarta una posible reforma en periodo islámico ${ }^{19}$. Para poder concretar más debería realizarse un estudio parietal exhaustivo, aunque un primer análisis nos obliga a admitir un reaprovechamiento general de material clásico, incluyendo piezas con engatillados. Incluso habría que preguntarse si las dovelas de los arcos, presumiblemente romanas, y aún siguiendo su orden original, fueron desmontadas y situadas de nuevo sobre los extremos del pasadizo dentro de una reforma islámica prealmohade ${ }^{20}$. En los muros del pasadizo la cantería se reapareja alternando filas de tizones con otras de simples sogas, disposición no observada en Coria, aunque, por otra parte, es ésta una formalización apreciada en numerosas construcciones romanas. En cualquier caso, la puerta sería luego integrada dentro de la gran obra muminí, construyéndose en su entorno la torre del Río para mejorar el flanqueo, y una posible torre hacia el norte, hoy desaparecida (véase infra).

\section{Puerta de Coria}

Estaba situada en el flanco septentrional del recinto, entre dos torres que se encuentran separadas entre sí 28 m; éstas son las del Socorro hacia el este y la del Rey al oeste. A pesar de que fue demolida en la segunda mitad del siglo $X V I^{21}{ }^{21}$, se conoce su ubicación exacta junto a la primera de las torres referidas, de cuyo basamento aún quedan restos empotrados dentro de una edificación posterior. También puede apreciarse el testimonio del antemuro que discurría paralelo a la muralla ${ }^{22}$, pero separado de ella en este tramo. Poco podemos aventurar acerca de la estructura medieval de la puerta de Coria, aunque existen ciertos elementos que pueden ayudarnos a trazar un hipotético esquema en planta. La torre del Socorro representaría su principal defensa, situándose a modo de espolón adelantado. La presencia de una hilada de sillares atizonados en la plaza inmediata, siguiendo un recorrido ortogonal a la muralla y paralelo al muro de comunicación entre la misma y la citada torre, parece representar el basamento o zócalo de un muro arrasado. En ese caso, podríamos hablar de una configuración morfológica de la puerta a modo de bastión, limitado por el citado muro, el de unión entre lienzo y torre del Socorro, y el que sirve de cierre entre ambos. El acceso sería de un simple codo, configurado por dos vanos: uno abierto al exterior posiblemente en el frente SE y por otro practicado en la muralla.

17 G. RODRÍGUEZ CEREZO, Op.Cit, 1988, p. 98.

I8 Atribuye esta cronología B. PAVÓN MALDONADO, Tratado de arquitectura hispano-musulmana II, Madrid, I999, p. 444.

19 Coincidimos de nuevo, en su apreciación global, con F. VALDÉS FERNÁNDEZ, Op. Cit., 1998, p. 176.

20 Esta cuestión se comprueba al verificar cómo las dovelas presentan marcas de grúas en su intradós.

21 Consúltese, M. M. LOZANO BARTOLOZZI, Op. Cit., 1980, p. 65.

22 En la pared de la casa situada en la calle Arco de España, N²8, lindante con el jardincillo de la plaza del Socorro, pueden apreciarse unos restos que pudieran pertenecer al citado antemuro. En conversación mantenida con F. J. Sellers, éste confirmó nuestra hipótesis; para más información remitimos a F. J. SELLERS BERMEJO et alii, Op. Cit., 1999, apartado 5.3. 


\section{Lienzos de muralla}

A la hora de realizar el estudio de los lienzos de muralla proponemos acometer el de aquellos más significativos, tanto por su buen estado de conservación como por la presencia de elementos singulares. De este modo, diferenciaremos:

\section{LIENZOS OCCIDENTALES}

\section{Tramos D-6 y 6-7.}

Como indica la denominación atribuida, se trata de dos tramos consecutivos de muralla situados en el frente occidental del recinto. El primero de ellos mide $26.40 \mathrm{~m}$ de longitud. Tiene adosado el cubo D muy cerca de su extremo septentrional, y el meridional limita con la cara norte del inicio del espigón de la torre del Aver. El segundo tramo arroja una longitud de $20.50 \mathrm{~m}$, entre la cara sur del mencionado paso albarrano y el extremo meridional. Los $40 \mathrm{~m}$ de lienzo comprendidos entre este punto y el comienzo del espigón de la Redonda, en la esquina sureste de la cerca, fueron demolidos en el siglo XIX ${ }^{23}$. Resulta especialmente interesante la observación de estas cortinas, puesto que los datos extraídos de su análisis nos permiten la reconstrucción ideal de su estado primitivo, con bastante aproximación, y la extrapolación de las conclusiones obtenidas al resto de muros de la cerca (Fig. 3).

El lienzo D-6 permanece limpio de construcciones adosadas a intramuros. Sin embargo, por su frente exterior se adhieren algunas casas, quedando ciertos paramentos libres hasta el nivel del adarve del antemuro. Este último ha sido desmontado en casi todo su recorrido a pie del tramo que nos ocupa. El muro tiene un grosor medio de $2.40 \mathrm{~m}$ y conserva todo el pretil, de $20 \mathrm{~m}$ de longitud, entre la cara sur del cubo y el inicio del espigón. A pesar de que los merlones han desaparecido, excepto el más septentrional, pegado al cubo, éstos podrían restituirse gracias a las huellas de sus almenas y los típicos rebajes curvos que se les asocian. Se aprecian vestigios de saeteras dispuestas del mismo modo que la del cubo D, a caballo entre el parapeto y la merlatura (véase infra). Una parte importante del alzado del muro está ejecutada en mampostería. Sobre ésta se elevan cuatro hiladas de tapias, la última de ellas correspondiente al pretil.

El lienzo 6-7 sufre una mutilación atípica, ya que toda la cara que mira al interior del recinto ha sido rebajada hasta dejar el grosor del muro reducido a $1.50 \mathrm{~m}$ aproximadamente. Conserva el pretil con las huellas de las almenas o intervalos, lo que nos permite restituir la ubicación y tamaño de los merlones. Así, sobre una longitud de $15.40 \mathrm{~m}$, podemos contar nueve merlones y nueve intervalos, perdiéndose todo rastro de huellas en los metros más meridionales del parapeto. Los mencionados elementos prismáticos arrojan una longitud que oscila entre 1.05 y $1.10 \mathrm{~m}$, y sus almenas entre 0.60 y $0.65 \mathrm{~m}$. En el pretil se abren cuatro saeteras, de alzado rectangular, abocinadas al interior y dispuestas con una cadencia regular, puesto que se ubican bajo merlones alternos. Este esquema cuenta con paralelos significativos en algunas estructuras conservadas tanto en la cerca de Elvas ${ }^{24}$ como en la de Écija ${ }^{25}$, lo que nos permite suponer que nos encontramos ante un modo constructivo habitual. Exteriormente, el lienzo tiene viviendas adosadas que solo dejan al descubierto las seis últimas hiladas de cofres de tapia, incluyendo la del parapeto. Por lo que se aprecia desde intramuros, todo el alzado del lienzo está constituido por sucesivas filas de cajones de arga-

23 El derribo fue llevado a cabo para construir, en su solar, un hospital promovido por el religioso que le da el nombre a la calle adyacente intramuros. Dicho edificio ha desaparecido en la actualidad.

24 Véase, F. B. CORREIA, "O sistema defensivo da Elvas Islâmica”, Mil anos de fortificaçoes na Península Ibérica e no Magreb (5001500), Lisboa, 2002, pp. 360 y 36I, Fig. 9.

25 Se identificaba esta disposición de las saeteras en el parapeto del lienzo cercano a la puerta del Sol; J. HERNÁNDEZ DÍAZ et alii, Catálogo arqueológico y artístico de la provincia de Sevilla, I-IV, Sevilla, I943-I95I, p. 2 I6, Fig. 579. 
masa. No hemos identificado zócalo de mampostería como basamento, que de existir, se reduciría a una simple obra de cimentación.

\section{LIENZOS ORIENTALES}

\section{Tramo 16-17}

Se encuentra ubicado en el frente oriental del recinto, entre las albarranas de los Pozos y del Río. Consta de muro y antemuro, separados en el enteste con el conjunto de los Pozos por 23m de distancia que constituyen la liza; esta magnitud se va reduciendo paulatinamente según avanzan las dos barreras hacia la torre del Río. En las proximidades de ésta median escasos 4 $m$ entre ambas. Los pobres vestigios de muralla existentes en este tramo, así como la mejor conservación del antemuro, y el desconocimiento generalizado de la existencia de este elemento, han llevado a la confusión popular sobre el carácter de la barrera exterior, que se identifica como muralla. Actualmente, el espacio comprendido entre ambas construcciones está colmatado hasta el nivel del adarve de la exterior; ignoramos si primitivamente fue concebido de este modo. En cualquier caso, hemos podido comprobar cómo en la práctica totalidad del perímetro de muralla se dispuso el antemuro sin mediar liza entre ambos ${ }^{26}$. Los motivos, por los que este lienzo supone una excepción a la norma, pueden ser tanto topográficos como poliorcéticos, aunque esta última hipótesis parece más lógica para el caso que nos ocupa. De este modo, la ubicación adelantada del antemuro permitía hostigar, desde una línea más avanzada, el camino que discurre por la pendiente más accesible hacia el arco del Cristo.

\section{Antemuros}

Autores ya clásicos han sugerido la posible existencia de antemuro en la muralla cacereña, negando, por otra parte, la subsistencia de cualquier vestigio material del mismo ${ }^{27}$. Un análisis exhaustivo del conjunto nos parece demostrar más bien lo contrario: que toda la muralla estaba rodeada por un antemuro con escarpa, curiosamente sin mediar apenas liza entre ambos elementos. Solo en ciertos tramos, como sería en las inmediaciones de las puertas y en el lienzo comprendido entre Pozos y Arco del Cristo, se apartaría ostensiblemente, como ya se comentó. A pesar de que esta defensa adelantada apenas si puede rastrearse más que en determinados tramos, sus vestigios nos aportan datos suficientes como para intentar una primera aproximación acerca de su morfología y trazado. Para ello, no sólo hemos de tener en cuenta los propios restos materiales conservados de los antemuros, sino también los de otros elementos asociados, como son los arcos practicados de forma sistemática en los espigones de las albarranas. El estudio metódico de ambas estructuras, unido a la total ausencia de cualquier tipo de barrera delante de las torres exentas, nos induce a pensar que el antemuro no rodeaba a éstas, sino que atravesaba los pasos albarranos a través de los vanos referidos. De forma excepcional los tramos del elemento en cuestión flanquearían los lados del espigón, llegando así hasta la albarrana, como puede observarse con claridad en la zona de la torre Redonda. Aunque suponemos que, en otros casos, el antemuro atravesaría el paso albarrano sin adosarse a sus caras, no tendremos la certeza de ello hasta que la arqueología lo confirme o lo desmienta.

Sí hemos podido comprobar cómo este elemento de barrera disponía originalmente de pretil y merlatura, idénticos a los observados en el remate de torres y muros. El dato nos lo proporciona un vestigio fosilizado en el lienzo meridional del baluarte de los Pozos (véase infra). La altura total que presentaría el antemuro sería variable dependiendo del tramo que consideremos. De este modo, en el mencionado sector de la torre Redonda su altura constituye la mitad de la de la muralla a la que adosa; mientras que, en la zona del cubo del

\footnotetext{
26 Los tramos de las puertas constituirían un caso excepcional, donde sí existiría una posible liza.

27 Así se manifiesta L. TORRES BALBÁS, Op. Cit., 1948, p. 466. Por otra parte, G. RODRíGUEZ CEREZO restringe la posible existencia de antemuro al flanco oeste del recinto, Op. Cit., 1988, p. 96.
} 
Olivar, apenas alcanza una quinta parte de la elevación de los lienzos y cubo adyacentes. Respecto a la anchura, en esta zona hemos podido recoger magnitudes variables entre 1.65 y $1.88 \mathrm{~m}$ en los tramos inmediatos a dicho cubo, y 2.30 m junto al cercano resto fósil referido.

\section{Torres albarranas}

Como ya se verá más adelante en la detallada descripción de cada uno de los bastiones defensivos, solamente tenemos constancia de dos albarranas con forma de prisma octogonal levantadas sobre una base cúbica, resolviéndose la transición entre ambos sólidos mediante planos triangulares inclinados. Todas las demás se constituyen como troncos de prisma o de pirámide. Los habitáculos situados a la altura del adarve muestran diferentes plantas y alzados, tanto en las dos octogonales como en la de los Pozos. Sin embargo, en las cuatro exentas, de planta cuadrangular, que apenas han sufrido modificaciones y que se hallan dispuestas consecutivamente en el flanco oeste, aparecen dos tipos de cámara de diferente forma a las anteriores pero repetidos por pares. Es posible suponer que estos últimos hubiesen sido extensibles al resto de albarranas del recinto, dado el carácter peculiar de las tres referidas en primer término. En cualquier caso, y con independencia del trazado adoptado en cada uno de estos habitáculos, lo que sí parece evidente es la función asignada a tales espacios; pues en ninguno se observan vestigios de apertura al exterior, como saeteras o ventanas de las que podamos asegurar su origen en el momento de erección de los bastiones. De este modo, parece que el uso destinado a las cámaras era el de servir de almacén de armas y pertrechos, y eventual habitáculo para la guardia que velaba los adarves.

\section{Torre de la Basura}

Se encuentra emplazada en el ángulo noroccidental del recinto. En el plano aparece indicada con el $\mathrm{N}^{\circ}$ I, y debió disponerse unos 37 $\mathrm{m}$ al oeste de la del Rey, y $65 \mathrm{~m}$ al norte de la de Bujaco. Responde también a los nombres de Buraca, Burraca, Buhaca y Bujaca ${ }^{28}$. De la torre no subsiste vestigio visible en la actualidad, pero su paso albarrano puede rastrearse, con bastante claridad, en planos de parcelario y otros ${ }^{29}$. La parte identificada del espigón arroja una longitud aproximada de $5 \mathrm{~m}$ y una latitud de $2.50 \mathrm{~m}$. La unión entre éste y el ángulo de la muralla se halla hoy día muy alterada, como resultado de haberse sucedido múltiples edificaciones y demoliciones. A pesar de todo, el aparejador Agustín Flores Alcántara, que ha estudiado el rincón con detenimiento, especula acerca de dos posibles vanos que conectaban el interior del recinto con el adarve del antemuro. Estos pasos debieron de ser de menguado tamaño, justo para el paso de una persona, y debieron de situarse uno a cada lado del encuentro entre el espigón y la muralla ${ }^{30}$. Parece ser que la parte inferior de la obra almohade aquí ejecutada se dispuso sobre tramos de sillares dispuestos a soga y tizón, tal vez material de acarreo preislámico ${ }^{31}$ (Fig. 4). La parte superior, tanto de muros como de espigón, fue levantada en tapia, como es habitual en el recinto cacereño.

\section{Torre de Bujaco}

Emplazada en el flanco occidental de la cerca. En el plano se marca con el № 2. Está situada $65 \mathrm{~m}$ al sur de la de la Basura y $70 \mathrm{~m}$ al norte de la de la Yerba. La profunda reforma que sufrió esta albarrana en el siglo XV ha impedido detectar cualquier elemento de la

28 Consúltese F. BRAVO Y BRAVO, "Las torres del Horno y de la Yerba tienen los nombres trastocados", Diario Extremadura, Cáceres, 28 Mayo 1975, p. 9; M. M. LOZANO BARTOLOZZI, Op. Cit., 1980, p. 69 ; y F. J. SELLERS BERMEJO et alii, Op. Cit., 1999, apartado 5.4 .

29 Véanse, entre otros planos, el de M. MATAS CASCOS, Plano de análisis de las murallas de Cáceres, escala 1:250, plano № 61; así como Plano de Cáceres del senvicio de cartografía digital municipal, escala de digitalización I:500, hojas 2762-E, 2762-G, 2763-A, 1997.

30 Datos extraídos de F. J. SELLERS BERMEJO et alii, Op. Cit., 1999, apartado 5.I, y entrevista personal con Agustín Flores Alcántara, que redactó el apartado del informe dedicado a esta torre.

3I Varias hiladas de ellos pueden verse en fotografías inéditas tomadas por Enrique Cerrillo en 1974, durante la intervención realizada por el constructor Antonio Abreu Tejero. 
primitiva obra de los Unitarios. Tal intervención consistió en forrar por completo el macizo de tapia y sustituir las cámaras originales por otras de nuevo cuño. La torre actual posee forma troncoprismática; el cuadrado de su base mide $11.50 \mathrm{~m}$ de lado, y alcanza el bastión una altura de $21.50 \mathrm{~m}$ en el remate piramidal de sus merlones. Estas dimensiones, unidas al hecho de ubicarse sobre una de las pendientes más suaves del promontorio, permiten suponer para la primitiva de Bujaco un tamaño y forma similares a la vecina de la Yerba. Las dos debieron de ser, con diferencia, las mayores albarranas de todo el conjunto amurallado.

\section{Torre de la Yerba ${ }^{32}$}

Se encuentra ubicada en el flanco occidental del recinto. En el plano aparece con el $\mathrm{N}^{\circ}$ 3 , y se sitúa $70 \mathrm{~m}$ al sur de la de Bujaco y 5 I $m$ al norte de la del Horno. En la actualidad está libre de viviendas parásitas en todo su perímetro excepto en un tramo de su cara oriental y la mitad de la cara septentrional. Todas las cotas, tanto de la torre como del espigón, se nombrarán tomando como referencia el plano horizontal imaginario que pasa por la base de la albarrana en su cara occidental.

La planta es un trapezoide casi cuadrado cuyos lados oeste y sur arrojan unas dimensiones de 7.90 y $8 \mathrm{~m}$ respectivamente. Sobre este último, y a 3.10 m de altura, se localiza una zarpa, actualmente muy erosionada, que retranquea 0.32 m la cara meridional. Como consecuencia de ello, la anchura del frente orientado a poniente se ve reducida a $7.58 \mathrm{~m}$. La torre tiene un desarrollo troncoprismático hasta 15 $\mathrm{m}$ de cota aproximadamente. De ahí hasta los $20.85 \mathrm{~m}$ de altura máxima, la forma de la torre se vuelve troncopiramidal. La planta de la terraza mide, comenzando por el lado oeste, y en sentido levógiro, $7.28 \times 7.75 \times 7.43 \times 7.90 \mathrm{~m}$. El paso albarrano arroja en el tramo correspondiente al actual foro de los Balbos una Ion- gitud II.97 m desde el bastión exento hasta la primitiva línea de muralla, demolida en 1930. El muro que hoy se contempla es una discutible reconstrucción de principios de la década de los setenta del siglo pasado; su frente avanza $0.97 \mathrm{~m}$ sobre el original y su adarve está situado $2.20 \mathrm{~m}$ por debajo del desaparecido. La cota del espigón, incluyendo pretil y merlatura, es de 17.20 m sobre el nivel de referencia. Sin embargo, la altura real se reduce a una media de 14 m sobre el terreno circundante, más elevado y horizontal que el primitivo, probablemente debido a sucesivas amortizaciones y nivelaciones.

Pensamos que el espigón se edificó sobre una torre de flanqueo más antigua ${ }^{33}$, cuya base arranca a una cota de entre 2.50 y $3 \mathrm{~m}$ de lo que debió ser la rasante original, y $5.45 \mathrm{~m}$ respecto a la cota cero. Tras dos zarpas, a 6.48 y $7.05 \mathrm{~m}$ de altura, sus restos alcanzan una cota de $9.20 \mathrm{~m}$. De ese punto nacería un arco desaparecido, que cobijaba el vano de aproximadamente $2 \mathrm{~m}$ de luz, actualmente cegado e irreconocible, y que atravesaba todo el grosor del paso albarrano conectando así los adarves de los diferentes tramos de antemuro. Esta torrecilla primitiva sobresaldría apenas $2.43 \mathrm{~m}$ del muro original, sin tener en cuenta las zarpas, y arroja una anchura de $3.90 \mathrm{~m}$ aproximadamente; la misma que la del espigón en la base. Esta magnitud se reduce a $3.50 \mathrm{~m}$ en el adarve a causa del desarrollo ligeramente ataludado de sus caras. El remate de la meridional conserva aún el pretil con sus correspondientes merlones, de los que se cuentan nueve en la actualidad. El encuentro entre el espigón y la albarrana se produce con evidente excentricidad, acercándose al extremo septentrional de la cara oriental.

Con respecto a su estructura interior, la albarrana alberga dos cámaras cuyo suelo se eleva 0.I I m sobre el adarve del paso inmediato. La oriental presenta planta trapezoide tendente al rectángulo, mientras que la occi-

\footnotetext{
32 Popularmente, ésta era conocida con el nombre de su vecina torre del Horno, y viceversa. Léase F. BRAVO Y BRAVO, Op. Cit., 28 Mayo 1975, p. 9.

33 Comenta esta cuestión referida a la presencia de torres islámicas prealmohades, F. VALDÉS FERNÁNDEZ, Op. Cit., 1998 , p. I73.
} 
dental sí es rectangular, con sus paredes totalmente paralelas a las caras exteriores de la torre. Se orientan sus lados cortos a norte y sur, y están cubiertas por sendas bóvedas de medio cañón, ligeramente rebajadas, con su eje de revolución perpendicular al espigón. Desde éste se ingresa al primer habitáculo a través de un vano, con arco escarzano, de $1.85 \mathrm{~m}$ de luz, entre 0.86 y $0.90 \mathrm{~m}$ de profundidad, y $1.98 \mathrm{~m}$ de altura. Comenzando por el lado occidental y en sentido levógiro, esta estancia tiene unas dimensiones de $4.90 \times 2.20 \times 5.04 \times 2.36 \mathrm{~m}$, alcanzando una elevación máxima de $2.56 \mathrm{~m}$ en la clave de la bóveda. Desde la parte sur de la habitación se accede a la terraza de la torre mediante una escalera organizada en tres tramos que, según asciende, va quebrando sucesivamente $90^{\circ}$ a izquierda. A la segunda cámara se penetra desde la primera franqueando un vano arcuado, más o menos alineado con el de la entrada a la exenta. Aquel tiene una profundidad de $0.66 \mathrm{~m}, 0.85 \mathrm{~m}$ de luz, y $1.92 \mathrm{~m}$ de altura. Nombrados, de la manera que nos es habitual, los lados de la segunda cámara arrojan unas medidas de $5.34 \times 2.42 \times$ $5.35 \times 2.46 \mathrm{~m}$, alcanzando una elevación máxima de $2.66 \mathrm{~m}$ en la clave de la bóveda. Su pared oeste está horadada por un gran hueco con ventana abierta al exterior. En la meridional encontramos tallada también una pequeña hornacina, así como en la septentrional de la primera habitación, que tiene otro hueco ${ }^{34}$. La autoría de estos rebajes no está clara en absoluto dados los datos que poseemos, por lo que no se puede descartar su origen tanto a modo de tacas utilitarias originales (quizás para candiles, dado su tamaño) como elementos retallados con posterioridad durante su conversión en viviendas o anejos de ellas.

En cuanto a la terraza, ésta mantiene todos los pretiles originales, sin embargo, sólo las merlaturas norte y sur lo son. La occidental es una inexacta reconstrucción ejecutada en los años sesenta del siglo $X X$, mientras que la cara opues- ta está rematada por un pretil sobreelevado que ocupa el lugar destinado a los merlones. En origen, cada parapeto debió recibir seis prismas, contando como dobles los de los extremos, que tendrían planta en forma de L; en la actualidad sólo presenta este esquema el correspondiente a la esquina noroeste, aunque la exploración de todo el pretil occidental proporciona indicios que nos permiten suponer similar organización para el vértice suroeste. Excepto el que mira al espigón, cada pretil está horadado por dos saeteras que se sitúan cada una bajo el merlón adyacente al esquinero. Estas troneras son de alzado rectangular, remate curvo y con derrame al interior. El grosor medio de parapetos y prismas es de $0.50 \mathrm{~m}$, salvo el oeste que, excepcionalmente, es de $0.37 \mathrm{~m}$. La longitud de los merlones oscila entre 0.85 y 0.95 $\mathrm{m}$, y la de sus intervalos entre 0.45 y $0.55 \mathrm{~m}$.

La torre está construida casi exclusivamente con tapia de hormigón de cal. Aunque la parte inferior de los ángulos está reforzada puntualmente con sillares graníticos, no se descarta que fueran insertados con posterioridad a su construcción, dada la irregularidad de su disposición. La altura de cada cajón oscila entre 0.80 y $0.90 \mathrm{~m}$. Debido a los parches y proyectados que sufre la superficie de la albarrana es difícil apreciar el número de hiladas que la componen. Aun así, puede estimarse un número total de veintidós, de las que las tres inferiores abarcarían desde la base hasta la zarpa; las catorce siguientes llegarían hasta el suelo de las cámaras, y las seis últimas hasta el coronamiento del bastión. El ladrillo se reservó exclusivamente para los arcos y bóvedas de las cámaras. El paso albarrano también está construido mediante encofrados, mientras que el cubo sobre el que asienta éste se resolverá con sillares graníticos.

\section{Torre del Horno}

Esta torre está ubicada en el flanco occidental de la cerca; en el plano se refleja con el $\mathrm{N}^{\circ} 4$.

34 En una fotografía de 1869, tomada desde la Plaza Mayor, se distingue una ventana que se correspondería con el hueco en cuestión. Hoy en día no se aprecia resto alguno de tal vano tras la última intervención restauradora. Véase en AA. VV., Cáceres, la historia viva, Cáceres, 1992, p. 23. 
Está situada $56 \mathrm{~m}$ al sur de la de la Yerba, y $5 \mathrm{I}$ $\mathrm{m}$ al norte de la del Postigo de Santa Ana. Debido a la inexistencia de construcciones adosadas en su cara septentrional se puede acotar su altura en $17.20 \mathrm{~m}$. Aprovechando esta circunstancia, todas las cotas, tanto de la torre como de su paso albarrano y de la muralla adyacente, se nombrarán tomando como referencia el plano horizontal imaginario que pasa por el nivel de la calle en la base de la albarrana. Su planta es un trapezoide casi cuadrado cuyo lado libre arroja una longitud de 6.80 $\mathrm{m}$. Sin embargo, medido sobre los merlones, el mismo lado mide $6.50 \mathrm{~m}$, el lado este 6.57 $\mathrm{m}$, el sur $6.70 \mathrm{~m}$ y el oeste $6.55 \mathrm{~m}$. Así pues, nos hallamos ante una torre claramente troncopiramidal (Fig. 5).

Desde la exenta hasta la muralla, el paso albarrano o espigón tiene una longitud de $6.25 \mathrm{~m}$, aunque su adarve mide en total $8.30 \mathrm{~m}$. Éste se halla a $4.80 \mathrm{~m}$ por encima del paso de ronda de la muralla que es interrumpida por el citado espigón. Es muy probable que esta última estructura no fuese más que la prolongación del muro interno que saliendo de la alcazaba, y separando el albacar de la medina, entestaba en la torre del Horno. Intramuros puede verse el roto del paso albarrano del que, en su parte inferior, se abrió un acceso escalonado muy empinado que, atravesando longitudinalmente el espigón, sale al exterior en el adarve del mismo junto a la puerta de la torre. La excavación de esta entrada debió de realizarse a la par que la destrucción del referido muro interno, puesto que a la vez que se condenó el único acceso fue necesario abrir otro. El adarve del paso albarrano se encuentra a una cota de $12.20 \mathrm{~m}$ y el del antemuro a $2.50 \mathrm{~m}$. Éste debió de adosarse a lo largo de las dos caras del espigón por ser éste tan corto. En el tramo norte de muralla adyacente se pueden apreciar los restos del antemural, a modo de relleno de tapia, más prominente que la cara exterior del muro. El paso albarrano apoya encima de una primitiva torre de flanqueo de la que se conserva un macizo de $5 \mathrm{~m}$ de altura por $3.60 \mathrm{~m}$ de anchura, idéntica a la del espigón, con 1.90 m de saliente. Puesto que la base de esta torrecilla está a la altura del adarve del antemuro, el arco del paso albarrano arranca, por hacerlo de la cima de aquella, a una cota de $7.50 \mathrm{~m}$ y tiene una luz de $1.25 \mathrm{~m}$. La distancia entre el intradós del arco y el adarve que discurre por encima es de $4 \mathrm{~m}$. El adarve de la muralla interrumpida por el espigón se halla al mismo nivel que la cima de la torre de flanqueo y que el arranque del arco (Fig. 2).

La torre alberga en su interior dos cámaras de planta trapezoide con tendencia al rectángulo, orientándose sus lados estrechos a norte y sur (Lám. 3). Están cubiertas por sendas bóvedas de medio cañón, ligeramente escarzanas, con su eje de revolución perpendicular al paso albarrano. Desde éste se accede a la primera cámara mediante un vano arcuado de $1.40 \mathrm{~m}$ de luz, entre 0.90 y I m de profundidad y $1.80 \mathrm{~m}$ de altura. La estancia tiene unas dimensiones de $4 \times 1.45 \mathrm{~m}$, alcanzando una altura máxima de $2.30 \mathrm{~m}$ en la clave de la bóveda. Desde la parte sur de la estancia se accede a la terraza de la torre mediante una escalera que, adosada interiormente a la pared oriental, alcanza en un rellano el ángulo interior sudeste $y$, tras un quiebro de $90^{\circ}$, asciende paralela a la cara meridional. A la segunda cámara se penetra desde la primera a través de un vano, con arco rebajado, prácticamente alineado con el de entrada a la albarrana. Aquel tiene una profundidad de $0.70 \mathrm{~m}, 1.20 \mathrm{~m}$ de luz y $1.65 \mathrm{~m}$ de altura. Tras la puerta, la cámara presenta el suelo rehundido unos $10 \mathrm{~cm}$ respecto la anterior. Nombradas en orden: oeste, norte, este y sur, las dimensiones respectivas de dicha estancia arrojan unos valores de 4.30 $\times 2.10 \times 4.30 \times 2.30 \mathrm{~m}$, alcanzando una altura máxima de $2.65 \mathrm{~m}$ en la clave de la bóveda. Todos sus muros, exceptuando el correspondiente al vano de acceso, están horadados por ventanas abiertas al exterior, ninguna de las cuales es obra primitiva, pues debieron practicarse cuando se transformó el interior de la torre en vivienda o anejo de una. De hecho, no consta en las albarranas cacereñas la existencia de cámaras con saeteras.

En cuanto a la terraza, ésta mantiene la merlatura y todos los pretiles originales salvo en el frente orientado hacia el espigón, que es el de levante. Los trece elementos prismáticos conservados se distribuyen de cinco en cinco por 
cada cara. Se cuentan dobles los de las esquinas suroccidental y noroccidental, por poseer planta en forma de $L$ en lugar de rectangular. Excepto en el frente este, en cada uno de los demás pretiles, bajo los merlones pares de cada frente, se sitúan dos saeteras de alzado rectangular y remate curvo con derrame al interior. El grosor de parapetos y de la merlatura es de medio metro aproximadamente, y sus alturas correspondientes coinciden con las de los cajones de tapial empleados en la construcción. La anchura de estos elementos prismáticos oscila entre 0.85 y $0.90 \mathrm{~m}$, y la de sus intervalos entre 0.45 y $0.55 \mathrm{~m}$. En éstos se pueden ver los típicos rebajes curvos que proliferan en pretiles almenados de obras militares Unitarias (véase infra).

La torre está construida casi exclusivamente en tapias hormigonadas, excepto la parte inferior, ejecutada con sillares graníticos reaprovechados de construcciones prealmohades. Cimenta directamente sobre un bloque de roca cuarcítica que sobresale hasta $0.90 \mathrm{~m}$ respecto al nivel de referencia; no se observa ningún trabajo de preparación del substrato base. Para acomodarse a este perfil irregular se utilizaron mampuestos y dos filas de sillares que generaron una base horizontal, a $1.80 \mathrm{~m}$, sobre la que se dispusieron otras dos hiladas más retranqueadas cinco centímetros respecto a las inferiores. Así, y a partir de este punto, situado a $2.50 \mathrm{~m}$ de altura, se inicia la obra de tapia. De un total de diecisiete hiladas, once corresponden al bloque macizo de la torre, cuatro a la cámara y dos a los pretiles y merlatura. La altura de cada encofrado es constante: $0.90 \mathrm{~m}$. A pesar de que el revestimiento ha desaparecido casi por completo todavía se observan restos de las franjas de mortero de cal que enmarcaban los cajones de tapia y del revoco, del mismo material, que cubría por completo parapetos y merlones. Las bóvedas de la cámaras, actualmente enlucidas, son de fábrica latericia, así como los arcos de entrada.

A causa de los parches existentes en la epidermis de estas construcciones no es fácil ver si están alineadas las hiladas de tapia de albarrana y espigón, aunque parece ser que así es. Por los datos disponibles actualmente no es posible saber si traban o no ambas estructuras. El paso albarrano también está cimentado sobre el mismo espolón rocoso y, al igual que la torre, se encuentra construido en tapia. Sin embargo, la parte de antemuro que discurre a sus pies es de mampostería. El cubo primitivo sobre el que asienta el espigón se ejecutó igualmente con fábrica de mampuesto reforzada con sillares esquineros, y trabada con mortero de cal. El arco que arranca de aquél se construyó con ladrillo.

\section{Torre del Postigo de Santa Ana}

Se encuentra ubicada en el flanco occidental del recinto. En el plano aparece con el $\mathrm{N}^{\circ} 5$, y se sitúa $5 \mathrm{I} \mathrm{m}$ al sur de la del Horno y $75 \mathrm{~m}$ al norte de la del Aver. Se llama así porque en época cristiana se abrió una puerta en la muralla junto al inicio de su paso albarrano o espigón. Es difícil conocer su altura exacta puesto que se halla rodeada de casas adosadas en todos sus frentes. Aun así se calcula tal magnitud en $18 \mathrm{~m}$ aproximadamente, de los que serían visibles sus últimos $9 \mathrm{~m}$ de alzado. Comenzando por la cara oeste, opuesta al espigón, y en sentido contrario a las agujas del reloj, su planta mide $6.84 \times 6.37 \times 6.81 \times 6.40$ $\mathrm{m}$ acotada en la terraza. Debido a la forma prismática de la albarrana, se le suponen a la base dimensiones similares o muy aproximadas. El paso albarrano arroja una longitud cercana a los quince metros, de los cuales los ocho más próximos a la torre son los que han sufrido menos modificaciones. Su anchura en el enteste con la albarrana es $2.40 \mathrm{~m}$, siendo sensiblemente mayor a $6 \mathrm{~m}$ de esta zona: $2.50 \mathrm{~m}$. En la parte más próxima a la muralla, el espigón es horadado por un vano con arco escarzano, por el que pasa una calleja. El arco sustituye a otro más estrecho que debió ocupar el mismo lugar y que cobijaba el paso de ronda del antemuro. A causa de la pendiente que experimenta el terreno donde asienta el paso albarrano, la altura de su adarve se reduce a poco más de seis metros en la unión con la muralla.

En el nivel del adarve, el espigón cuenta con parapetos laterales que, según se van acercando a la torre, se elevan escalonadamente, 
hasta tres veces su altura, para proteger la escalera que asciende, por su parte sur, a la terraza que hay sobre la cámara (Fig. 6). A ésta se accede a través de un vano que originariamente tuvo $1.60 \mathrm{~m}$ de profundidad.

En planta, la cámara se halla descentrada respecto a la torre y tienen sus muros espesor variable (Lám. 4). Cabe destacar el enorme grosor de $2.40 \mathrm{~m}$ del que mira a poniente. La ubicación de los lados largos y cortos de esta estancia coincide con los de la torre: sus frentes más anchos miran al este y oeste. Volumétricamente expresado, la habitación podría asemejarse a un baúl. Su planta es un trapezoide de $3.62 \times 2.70 \times 3.57 \times 2.73 \mathrm{~m}$ con tendencia al rectángulo. A 2 m de altura arranca una bóveda de medio cañón, ligeramente escarzana, con su eje de revolución perpendicular al paso albarrano. La cámara alcanza una elevación máxima de $3.20 \mathrm{~m}$ en la clave de la bóveda, la cual posee un grosor en este punto de aproximadamente $0.50 \mathrm{~m}$. En cada cara corta del habitáculo se ubica una hornacina cuadrangular que encaja en la altura de la segunda fila de cajones de tapia contada a partir del suelo.

En cuanto a la terraza, ésta mantiene todos los pretiles originales, al igual que sucede con la merlatura, excepto en el frente orientado hacia el paso albarrano. Los diez elementos prismáticos conservados se distribuyen de la siguiente manera: cuatro sobre el parapeto oeste y tres encima de cada uno de los pretiles norte y sur. Puesto que los merlones esquineros no adoptan aquí planta de L, el canto de los exteriores de la fachada oeste está alineado con las caras externas de los prismas de los frentes norte y sur. Sobre el parapeto oriental, que mira hacia el espigón, se alzan actualmente tres merlones modernos que no guardan la ubicación de los originales que sustituyen. A pesar de ello, sería posible restituir el mer- lón más meridional del pretil mencionado con garantías de devolverle sus dimensiones y colocación primitivas. En los parapetos, bajo los dos merlones centrales de cada frente, excepto a levante, se sitúan dos saeteras de alzado rectangular y derrame al interior. El grosor de los elementos aquí mencionados es de medio metro y sus alturas correspondientes coinciden con las de los cajones de tapial empleados en la construcción. La anchura de los merlones oscila entre 1.46 y $1.25 \mathrm{~m}$, y la de sus intervalos entre 0.49 y $0.68 \mathrm{~m}$. Si se comparan estas medidas con las de otras fortificaciones almohades coetáneas, se comprueba cómo las de esta torre son bastante más anchas, incluso el doble en algunos casos ${ }^{35}$.

De la parte superior de la torre permanecen visibles hasta diez hiladas de tapias. A pesar de que los primeros metros de alzado quedan ocultos por el caserío, contamos con el testimonio del arquitecto Miguel Matas Cascos, quien reconoció en esta zona un aparejo de sillares graníticos. Desconocemos la altura que alcanza el basamento pétreo del que formaría parte tal aparejo; aunque, al parecer, en su cara de levante se elevaría entre cinco y diez metros sobre el terreno situado a sus pies ${ }^{36}$. En cualquier caso, es posible que el zócalo en cuestión no contase con el mismo número de hiladas en todos sus frentes, pues asienta sobre un terreno en fuerte desnivel. En lo que respecta al espigón, sin contar las hiladas correspondientes a pretiles y merlatura, la obra de tapia se reduce a una fila superior de cajones de hormigón de cal que corona un elevado basamento de mampostería.

Todavía subsisten vestigios de los revestimientos originarios de la torre, tanto de las típicas cintas de mortero de cal que bordean los cajones de hormigón, como del enlucido hidrófugo que cubre parapetos y merlones.

35 Compruébese en comparación con lo referido por B. PAVÓN MALDONADO, Op. Cit., 1999, p. 288.

36 El citado arquitecto asegura que pudo observar el citado paramento en el interior de una habitación que ocupa la tercera planta de un inmueble adyacente. Dado que el reconocimiento fue realizado hace ya algunos años, en el transcurso de unas obras, a día de hoy tales vestigios están ocultos tras un enlucido. Por desgracia, no existe documentación fotográfica que nos permita estudiar la disposición de la sillería. 


\section{Torre del Aver}

La siguiente albarrana, aunque también responde al nombre de torre del Postigo, se conoce por torre del Aver y por sus variantes Laver, Avero y La Ved ${ }^{37}$ (Figs. 3 y 7). Se ubica en el flanco occidental de la cerca; en el plano aparece con el $\mathrm{N}^{\circ} 6$ y está situada $75 \mathrm{~m}$ al sur de la del Postigo de Santa Ana, y $67 \mathrm{~m}$ al norte de la octogonal conocida como Redonda.

Gracias a que su frente oeste está libre de casas adosadas se ha podido determinar su altura en $19.50 \mathrm{~m}$ aproximadamente. Aprovechando esta circunstancia, todas las cotas, tanto de la torre como de su paso albarrano y de la muralla adyacente, se nombrarán tomando como referencia el plano horizontal imaginario que pasa por el nivel de la calle y la base de la albarrana. La planta es un cuadrado de 6.80 $\mathrm{m}$ de lado y la forma de la torre es aparentemente prismática. El espigón arroja diferentes longitudes, pues la muralla experimenta un quiebro en cremallera en el encuentro entre ambos. Así pues, mientras que la cara norte del paso mide $10.40 \mathrm{~m}$, la correspondiente al sur solamente arroja $8.95 \mathrm{~m}$. A pesar de que se calcula su anchura en $2.77 \mathrm{~m}$ aproximadamente, no es posible conocer el valor exacto de esta magnitud en su adarve, que transcurre a una cota de $13.70 \mathrm{~m}$, porque la parte superior de la cara septentrional está desmoronada en la actualidad. Éste es el segundo espigón de todo el conjunto de Cáceres en el que se ha podido constatar la presencia de dos vanos. Comenzando por la muralla, el arco del primer hueco arranca, a una cota de $10 \mathrm{~m}$, desde el remate de lo que queda de una torre de flanqueo prealmohade. Tiene una luz de I m y la distancia entre su trasdós e intradós es de $0.50 \mathrm{~m}$. El vano cobijado por este arco debe su existencia al paso de ronda del antemuro que discurre a pie de muralla y atraviesa los pasos alba- rranos. Y si se considera que ese adarve está a idéntico nivel que el suelo intramuros, se puede calcular la altura de este hueco en unos $5.50 \mathrm{~m}$ aproximadamente sobre el mencionado paso, que a su vez tendría en ese punto una cota de $4.60 \mathrm{~m}$. Entre el intradós de la clave del arco y el adarve que pasa por encima hay un grosor de $3 \mathrm{~m}$. El arco del segundo vano se empotra en el macizo de la torre, arranca a una cota de $8.30 \mathrm{~m}$ y tiene una luz de 2.15 $\mathrm{m}$, siendo la distancia entre el trasdós e intradós de $0.90 \mathrm{~m}$. Coincide, incluyendo la rosca, con la altura de dos hiladas de tapias.

Al margen de la torre del Aire, también en Cáceres, existen al menos dos ejemplos conocidos de pasos albarranos horadados por un par de arcos en otras fortificaciones. Uno es el situado junto a la puerta de Sevilla en Córdoba. Al parecer, el arco más próximo al muro cobijaba el paso de ronda del antemuro, al igual que en Cáceres, salvando el segundo arco un foso defensivo ${ }^{38}$, que en el caso que nos ocupa, sería más complicado demostrar. El segundo ejemplo es más próximo: la albarrana del albacar de Trujillo. Formalmente es muy similar a las torres del Aver y del Postigo de Santa Ana, pues son idénticas las cámaras y su disposición, así como el acceso a la terraza almenada. Las coincidencias continúan en los espigones, pues en Trujillo el paso nace también de una torre más antigua, cilíndrica ésta, aunque el vano más próximo a la exenta no tendría una función definida o aclarada. Así, la única diferencia estriba en que, mientras en la del Aver el primer arco claramente salva el adarve del antemuro, en Trujillo no se conservan vestigios de posible antemural rodeando el albacar.

En el nivel del adarve, el paso albarrano estaba dotado de pretiles laterales que, según se iban acercando a la torre, se elevaban escalonadamente hasta tres veces su altura para

37 El repertorio de denominaciones se cita en M. M. LOZANO BARTOLOZZI, Op. Cit., 1980, p. 7I; G. RODRÍGUEZ CEREZO, Op. Cit., 1988, p. 103; así como en F. BRAVO Y BRAVO, Op. Cit, 28 Mayo 1975, p. 9. La segunda de las variantes aparece únicamente en el ya citado Plano de Cáceres del senvicio de cartografía digital municipal, escala de digitalización I:500, hojas 2762-E, 2762-G, 2763-A, 1997.

38 Refiere esta cuestión L. TORRES BALBÁS, “Las torres albarranas", al-Andalus, VII, I, Madrid-Granada, 1942, p. 219. 
proteger la escalera que, por su parte norte, ascendía a la terraza que corona la albarrana ${ }^{39}$. Actualmente, el parapeto septentrional ha desaparecido totalmente junto con la escalera y con parte del adarve debido al desmoronamiento anteriormente mencionado. Sin embargo, a pesar de que la parte escalonada del pretil meridional tampoco se conserva, hay documentación fotográfica que atestigua la existencia de dicho elemento con una morfología similar a los conservados en la torre del postigo de Santa Ana ${ }^{40}$. Afortunadamente sí ha llegado a nuestros días la primera hilada del pretil sur con dos saeteras conservadas y vestigios de una posible tercera. La primera de ellas, la más cercana a la torre, es diferente al tipo habitual localizado en los parapetos de la fortificación, con derrame y esviada hacia el oeste. Y puesto que no está situada justo encima del arco mayor, sino sobre la prolongación de su jamba este, el esviaje podría haber sido concebido para poder batir desde esta posición la zona inmediata al vano en cuestión.

$\mathrm{Al}$ interior de la torre se accede mediante un vano arcuado de $1.35 \mathrm{~m}$ de profundidad, 0.85 $\mathrm{m}$ de anchura y $2.05 \mathrm{~m}$ de altura. En planta, la cámara se halla descentrada respecto a la torre y sus muros tienen espesor variable. Cabe destacar el gran espesor de $2.20 \mathrm{~m}$ del orientado a poniente. La habitación tiene forma de baúl y su planta es un trapezoide de $3.63 \times 2.82 \times$ $3.52 \times 2.77 \mathrm{~m}$ con tendencia al rectángulo. A $2.20 \mathrm{~m}$ de altura arranca una bóveda de medio cañón, de perfil ligeramente rebajado, con su eje de revolución perpendicular al paso albarrano. La estancia alcanza una altura máxima de 3.37 m en la clave de la bóveda, separada de la superficie de la azotea por un grosor de, aproximadamente, $0.50 \mathrm{~m}$. Así pues, la cámara tiene forma, tamaño y ubicación respecto a la torre, prácticamente idénticas a las estudiadas en la albarrana del postigo de Santa Ana. En este caso, una de las escasas diferencias observables es la ausencia de hornacinas. En el momento de la destrucción de la escalera exterior debió practicarse el hueco que rompe la bóveda para acceder, mediante otra escamoteable, a la terraza. Actualmente, y tras la última restauración, la salida a la azotea se encuentra condenada por una placa translúcida ondulada.

En cuanto al terrado, éste mantiene todos los pretiles y merlatura originales excepto en el frente orientado hacia el paso albarrano. Los doce elementos prismáticos conservados se distribuyen de cuatro en cuatro sobre cada uno de los parapetos norte, oeste y sur. Señalemos que los merlones esquineros no adoptan planta de L. De esta forma, el canto de los prismas extremos de la fachada oeste está alineado con las caras externas de los merlones de los frentes norte y sur, dando la apariencia de haber cinco de estos elementos sobre cada uno. Coronando el pretil oriental, y hacia el espigón, se alzan actualmente tres merlones restituidos en la última restauración que, de manera bastante aproximada, guardan la ubicación de los originales que sustituyen. Cada parapeto, excepto el de levante, aparece perforado por una pareja de saeteras rectangulares y derrame al interior. El grosor de pretiles y merlatura es de $0.50 \mathrm{~m}$ aproximadamente $y$ sus alturas correspondientes coinciden con las de los cajones de tapial empleados en su construcción. La anchura de los merlones de la cara oeste oscila entre 1.10 y $1.20 \mathrm{~m}$, y la de sus intervalos entre 0.65 y $0.72 \mathrm{~m}$, siendo estas dimensiones más reducidas en las fachadas norte y sur. En éstas la anchura de los prismas oscila entre I y $1.08 \mathrm{~m}$, y la de sus intervalos entre 0.48 y $0.67 \mathrm{~m}$. Entre los merlones pueden apreciarse los rebajes curvos ya aludidos, característicos de las fortificaciones muminíes.

39 Se comenta la alteración del espigón en M. MATAS CASCOS, "Intervenciones en la muralla de Cáceres", La ciudad y sus murallas, Granada, 1996, p. 27I. En cualquier caso, en conversaciones personales, Miguel Matas fue más explícito y corroboró la destrucción de parte del paso albarrano, así como las modificaciones consiguientes para acceder al terrado del bastión, actualmente desde la cámara. En una visita efectuada por uno de los autores de este artículo, se pudieron comprobar todas estas transformaciones.

40 Véanse las imágenes de la torre del Aver publicadas por J. R. MÉLIDA, Catálogo Monumental de España. Provincia de Cáceres, Madrid, 1924, Lám. XLI, Fig. 69, y M. A. ORTí BELMONTE Op. Cit., 1954, p. II. 
La torre está construida casi exclusivamente con tapiales de hormigón de cal, excepto la parte inferior que se ejecutó con sillares graníticos reaprovechados de construcciones anteriores ${ }^{41}$, alguno con almohadillado de clara factura romana. Toda ella está calzada sobre un lecho de mampostería visible sobre la rasante de la calle en su último medio metro; es posible que esta fábrica forme parte de la cimentación y haya quedado al descubierto con el paso del tiempo. El zócalo pétreo que se halla inmediatamente por encima tiene una altura de $3.45 \mathrm{~m}$, de los que los $1.75 \mathrm{~m}$ primeros corresponden a tres filas de sillares de gran tamaño, oscilando sus alturas entre 0.50 y $0.60 \mathrm{~m}$. Los $1.70 \mathrm{~m}$ restantes se distribuyen en cuatro filas de sillares de 0.40 a 0.43 de altura. Se alternan sogas y tizones sin un módulo determinado de regularidad, predominando los segundos en la primera hilada. Los sillares están trabados con un aglomerante muy rico en cal, y probablemente fuesen revocados con un mortero rojizo del que se pueden observar restos en algunas llagas ${ }^{42}$. A una cota de cuatro metros sobre el terreno comienzan a elevarse las tapias sobre el zócalo pétreo. De un total de diecisiete hiladas, once corresponden al bloque macizo de la torre, cuatro a la cámara y dos a los pretiles y merlatura. La altura de cada hilada se sitúa en torno a 0.90 $\mathrm{m}$. A pesar de que el revestimiento ha desaparecido casi por completo en toda la epidermis de la construcción, todavía existen restos de las líneas de mortero de cal que enmarcaban los cajones de tapia y del revoco, del mismo material, que cubría por completo parapetos y merlones. La bóveda de la cámara, actualmente enlucida, es de ladrillo, así como la rosca del arco de entrada. En este punto dichos elementos cerámicos llegan a medir $22 \times 29 \mathrm{~cm}$. Las albanegas del arco son de mampostería trabada con mortero de cal y rematadas por una línea de ladrillos que sirve de lecho a la tapia superior.
Existe un desfase de $0.30 \mathrm{~m}$ de altura entre las hiladas de la torre y las de su paso albarrano. Posiblemente ello se deba a que la exenta y su espigón no están unidos en su base, sino a partir del arco que las traba a una cota de $8.30 \mathrm{~m}$. En cualquier caso, las tapias de ambos elementos, situadas por encima del arco, no enjarjan como tampoco sucede en otras construcciones, como vemos que ocurre, por ejemplo, en la albarrana del recinto de Calatayud. Debido a la desaparición del parapeto escalonado meridional del paso albarrano, es posible ver, en el encuentro entre lo que queda de dicho pretil y la torre, un pequeño hueco tallado en ésta en el que penetra la masa de tapia de la hilada conservada del espigón. La intención de este recurso fue, sin duda, la de proporcionar una mínima cohesión entre las dos estructuras para evitar movimientos de desplome. Todavía puede observarse en la superficie de la torre, allí donde adosaban las tapias desaparecidas del espigón, restos del revoco en buen estado por haber estado cubiertos hasta fechas más recientes.

Es difícil saber cómo se levantó la parte inferior del paso albarrano puesto que está oculta por construcciones parásitas, aunque es posible que las tapias visibles en la actualidad se apoyen sobre un zócalo de mampostería. Sus arcos son de ladrillo de gran formato, y la primitiva torre de flanqueo, de la que nace el primer vano del paso, tiene un zócalo de cinco hiladas de sillería granítica sobre el que se eleva obra de mampostería con sillares esquineros.

\section{Torre Redonda ${ }^{43}$}

Así mal llamada a causa de su forma de prisma octogonal (Fig. I). Se sitúa en el ángulo suroeste del conjunto, a $67 \mathrm{~m}$ al sur de la del Aver y a $55 \mathrm{~m}$ de la hipotética albarrana

4I Sin ir más lejos, algún autor ha llegado a identificar injustificablemente las tres primeras hiladas de sillares con restos de una obra celtíbera. Consúltese C. CALLEJO SERRANO, Cáceres monumental, Madrid, 1972, p. 35.

42 Agradecemos la advertencia sobre tales vestigios por parte de Enrique Cerrillo.

43 Esta albarrana fue estudiada por vez primera por Leopoldo Torres Balbás, quien también dibujó la planta de la cámara y un alzado en sección de la misma. Véase L. TORRES BALBAS, Op. Cit., 1948, pp. 464 y 465. Posteriormente, han sido escasos los estudios dedicados a esta torre, limitándose a descripciones formales, más o menos someras, sin entrar en detalles constructivos. Consúltese G. RODRÍGUEZ CEREZO, Op. Cit., 1988, p. I03, y B. PAVÓN MALDONADO, Op. Cit., 1999, p. 269. 
de la calle Cornudillas. En el plano aparece reflejada con el $\mathrm{N}^{\circ}$ 7. En planta forma parte de un gran macizo rectangular del que se elevan la propia torre, su paso albarrano y los tramos de antemuro que lo flanquean. Este paralelogramo mide $21.50 \mathrm{~m}$ en sus lados noroeste y sudeste, por $8.90 \mathrm{~m}$ en el suroeste, adosándose a la muralla el noreste. La exenta pasa de planta cuadrangular a octogonal a unos $6 \mathrm{~m}$ de altura mediante cuatro planos triangulares inclinados, de los cuales sólo es visible el situado entre la torre y el antemuro en el frente SO. Los demás, así como toda la base cuadrangular, están ocultos por viviendas adosadas. De este modo, y por encima de este nivel, el cuerpo octogonal de la albarrana se eleva $11.40 \mathrm{~m}$ más hasta el pretil de su terraza. Si a esto se añade la cota de los merlones, se puede estimar la altura del bastión en 18 m aproximadamente. Los lados del octógono miden entre 3.50 y $3.80 \mathrm{~m}$, y es en su planta donde se aprecia cierta irregularidad del polígono.

A la cámara se ingresa a través de un vano arcuado ubicado en la cara nordeste de la torre, la que comunica con el espigón. Una escalera de seis peldaños, de alturas irregulares, salva los $1.25 \mathrm{~m}$ de diferencia media de cotas que hay entre el suelo de la estancia y el del paso albarrano. Solamente los cuatro últimos escalones ascienden bajo el cañón del vano de $1.15 \mathrm{~m}$ de luz, $1.40 \mathrm{~m}$ de profundidad, $2.65 \mathrm{~m}$ de altura sobre el primer peldaño que cobija y 2.10 $\mathrm{m}$ sobre el postrero. Debido a la leve inclinación que sufre el suelo de la habitación, las cotas tomarán como referencia el nivel de éste bajo el arco central que separa los espacios principales. La cámara está dividida en seis tramos de diferente volumen, sin contar con el hueco de la escalera que sale a la terraza (Lám. 5). Son dos pilares, de planta cruciforme el derecho y con forma de T el izquierdo, los que organizan la distribución del espacio mediante arcos de medio punto de $2.25 \mathrm{~m}$ de cota en las claves. Los dos tramos mayores son de planta trapezoidal, muy cercana a cuadrados de $2.50 \mathrm{~m}$ de lado, y cubiertos por bóvedas baídas de $3.40 \mathrm{~m}$ de altura en los centros. Ocupan el tercio central de la torre y están alineados con el espigón. A izquierda y derecha de cada uno se ubican sendos espacios con planta de tra- pecio recto cubiertos por bóvedas de medio cañón, e incluso de cuarto de cañón en algunas partes, no rebasando su altura los $3 \mathrm{~m}$. Los tramos periféricos situados justo a la derecha se comunican por un arco, alterado hoy día, originariamente semicircular de 1,8 $\mathrm{m}$ de altura hasta la clave. El suelo del espacio secundario sito a izquierda del segundo tramo principal está elevado, por un par de escalones, respecto de éste. Desde aquí asciende la escalera que, pasando por encima de otro de los espacios laterales, desembocan en la terraza tras hacer un quiebro de $96^{\circ}$ en una meseta. Es, precisamente, esta última parte de la escalera en donde sus paredes y bóvedas sobresalen del suelo de la azotea generando un castillete con planta de L. Todo el recorrido ascendente, incluido el tramo secundario previo, va cubierto por una bóveda escarzana rampante que experimenta interiormente un escalonamiento al superar el suelo de la terraza. Al exterior, este accidente coincide con la aparición del mencionado castillete.

El terrado cuenta con su todos sus parapetos y merlatura correspondientes. De un total de dieciséis prismas, la mitad se sitúan sobre los vértices del octógono y los demás en el centro de cada lado. Cada pretil, bajo el merlón central correspondiente, se encuentra perforado por una saetera con derrame al interior. Es preciso mencionar la del parapeto oriental, pues, a diferencia de las demás, se encuentra esviada para proporcionar una posición de tiro más cómoda al tirador de turno, al cual debió estorbar bastante el castillete de salida a la terraza. El único pretil que carece de aspillera es el orientado al paso albarrano. En su lugar adosa interiormente un banquito corrido que parece original y cuyo destino no parece ser otro que servir para descanso del vigía.

Una altura de $6 \mathrm{~m}$ separa el borde del parapeto del suelo del espigón, aproximadamente la misma distancia que media entre el de éste y el del antemuro visible. La anchura del paso albarrano es de $3.80 \mathrm{~m}$, idéntica medida que presenta la cara de la torre en que entesta, mientras que la correspondiente al antemuro es de $2.65 \mathrm{~m}$. Su único paramento conservado actualmente puede verse en un pequeño patio de 
unas construcciones parásitas emplazado en la parte suroriental. Por lo que se puede percibir, la faz externa del antemuro debió ser coplanaria con una de las caras del zócalo cuadrangular que constituye la base de la exenta, y por ende, de la fachada de la parte octogonal que prolonga la de la base. Dicho espigón, como es habitual en este recinto, estaba perforado por un arco que comunicaba los dos tramos de adarve del antemuro situados a cada lado. A pesar de que el vano se halla cegado en parte, es posible rastrear su línea de intradós y dar unas dimensiones aproximadas de $2 \mathrm{~m}$ de luz por $3.5 \mathrm{~m}$ de altura en la clave; la jamba más cercana a la albarrana está a menos de 3.5 m de la misma.

A día de hoy no tenemos certeza de qué materiales fueron empleados en la construcción del zócalo cuadrangular de la torre. Aun así, se puede aventurar que probablemente sean sillares graníticos los que conformen la base, pues en el plano inclinado de la cuña triangular visible se aprecia, en la parte más elevada, una fila de sillares de granito trabados con mortero de cal y pequeñas piedras en las llagas. El resto del plano va cubierto por grandes lajas de pizarra, sin duda dispuestas de manera que ayuden al rápido drenaje de la superficie. Incluso por encima de la mencionada línea pétrea, pero ya en el prisma octogonal, se observa otra fila de sillares que, a diferencia de la anterior, va embutida en un plano vertical. Desde esta cota hasta el coronamiento de la torre se suceden un total de quince hiladas de cajones de tapia, de las que ocho forman el cuerpo macizo, cinco coinciden con la cámara y las dos últimas con pretiles y merlones. La altura de los encofrados oscila entre 74 y $80 \mathrm{~cm}$, exceptuando la hilada inmediatamente inferior al parapeto, de $50 \mathrm{~cm}$. Sin duda, esta anomalía se debe a la necesidad de encajar la elevada altura de las bóvedas baídas de tal forma que la distancia entre sus claves y el suelo de la terraza no sea excesiva, como habría sucedido en el caso de ser similares todas las cotas de los cajones. Por otra parte, no habría sido posible coordinar la elevación de las bóvedas con solamente cuatro hiladas, como ocurre en todas las demás albarranas, puesto que la altura de las baídas habría sobrepasado la cuarta fila de encofrados. Todavía pueden distinguirse, en la cara oriental del octógono, restos del fajeado que enmarcaba cada cajón.

A pesar de hallarse enlucido el interior de la estancia de la torre por sucesivas capas de cal, es lógico suponer que, como mínimo, arcos y bóvedas sean de ladrillo y posiblemente también los pilares. Claramente es de este material el medio cañón del vano de acceso al interior de la Redonda. Tanto las caras externas del espigón como de la parte visible del antemuro están muy alteradas y parcheadas con mampostería. Únicamente se percibe con claridad un fragmento de tapia del antemuro, aparentemente original, justo bajo su pretil.

\section{Supuesta torre de la calle Cornudillas}

Se situaría en el flanco sur de la cerca. En el plano se marca con el $N^{\circ} 8$ y estaría ubicada, aproximadamente, entre la torre Redonda y la conocida como de Mari Lucas. La posible existencia de esta albarrana fue planteada por los aparejadores Agustín Flores Alcántara, José Luis Antúnez González, José Luis Sánchez de la Calle y Francisco Javier Sellers Bermejo ${ }^{44}$. Entre otros argumentos esgrimidos para justificar su existencia, el más determinante parece ser la exagerada distancia que encontramos entre la Redonda y la puerta de Mérida, circunstancia que, desde luego, no justifica en absoluto tal hipótesis. Por otra parte, sí es cierto que este tramo de muralla está flanqueado por dos cubos, y, precisamente, el concepto global de fortificación planteado en Cáceres parece evitar la disposición de dos torres adosadas consecutivas, decantándose por la alternancia entre cubos y albarranas. Todo ello invita a suponer que entre los dos cubos pudiera disponerse la albarrana en cuestión.

44 Consúltese F. J. SELLERS BERMEJO et alii, Op. Cit,, 1999, apartado 7.3. 
La existencia de esta torre no deja de ser, por tanto, una mera hipótesis de trabajo, siendo precisa para su verificación la aportación de nuevos datos de fuentes históricas o de carácter arqueológico.

\section{Torre de Mari Lucas}

Aparece emplazada en el flanco meridional de la cerca. En el plano se marca con el $N^{\circ} 9$. Debió de ubicarse, aproximadamente, a oriente de la de Cornudillas, y a occidente de la puerta de Mérida. También aparece citada en la documentación histórica como del Potro de Santa Clara. No queda vestigio alguno de esta albarrana, pero, al contrario que la anterior, su existencia está referida en crónicas y avalada por las opiniones de diversos investigadores ${ }^{45}$.

\section{Supuesta torre de Mérida}

Se encontraría situada en el frente meridional del recinto. Aparece reflejada en el plano con el $N^{\circ}$ I0. Se localizaría en las proximidades de la torre de Mari Lucas, en el entorno de la desaparecida puerta de Mérida. A falta de otra denominación de carácter tradicional, le hemos asignado el mismo nombre con que la refiere Fernando Bravo y Bravo. A pesar de las referencias de otros investigadores, no existe documentación concreta referida a la torre. Sin embargo, las necesidades poliorcéticas parecen justificar la existencia de dos exentas, ésta y la de Mari Lucas, que debieron de conformar las defensas de la puerta de Mérida, tal y como se comentó en su momento. Una vez más, el equipo de aparejadores referido anteriormente ofreció argumentos para poder especular acerca de la existencia de tal bastión ${ }^{46}$.

\section{Torre de la calle Torremochada}

Localizada en el flanco meridional de la cerca. En el plano aparece señalada con el $N^{\circ}$ II. Se emplaza al este de la de Mérida y $46 \mathrm{~m}$ al oeste de Torremochada. A pesar de su buen estado de conservación, no ha sido conocida por la comunidad científica hasta que, en 1994, la localizó el aparejador Javier Sellers ${ }^{47}$. Por este motivo, la albarrana no responde a ningún nombre tradicional, por lo que la designamos con el correspondiente a la calle más cercana.

No es fácil dar medidas exactas de la torre y su paso, puesto que se encuentran totalmente embutidos en otras edificaciones. La base de la torre es un cuadrado de poco más de $4 \mathrm{~m}$ de lado, y su altura no debe superar los $12 \mathrm{~m}$. No se conserva cámara, y quizá nunca la tuvo, dadas las reducidas dimensiones de su planta. El espigón mide, aproximadamente, unos $4 \mathrm{~m}$ de longitud y está perforado, en su parte más cercana a la muralla, por el inevitable vano arcuado que cobijaba el paso del adarve del antemuro; un tramo de éste parece subsistir a poniente del espigón. Toda la obra está ejecutada, como es habitual, con tapia, y con ladrillo como material complementario.

\section{Torremochada}

En el plano aparece con el $\mathrm{N}^{\circ} 12$. Se emplaza en el flanco sur del enclave, $46 \mathrm{~m}$ al este de la albarrana de la calle Torremochada y $52 \mathrm{~m}$ al suroeste de la de la calle Hernando Pizarro. Como su nombre indica, se encuentra desmochada a partir del arranque de las bóvedas de la cámara, alcanzando actualmente una altura de unos $16 \mathrm{~m}$ sobre el terreno circundante, aunque en su estado primitivo debió de llegar hasta los $19 \mathrm{~m}$ aproximadamente (Fig. 8).

Al igual que la conocida como Redonda, posee base cuadrada y se transforma en octogonal mediante unos planos triangulares inclinados, de los que son visibles los de correspondientes a los ángulos suroeste y sudeste ${ }^{48}$. Los dos restantes están ocultos por casas ado-

\footnotetext{
45 Véase F. BRAVO Y BRAVO, Op. Cit., 28 Mayo 1975, p. 9, y M. M. LOZANO BARTOLOZZI, Op. Cit., 1980, p. 71. 46 Se comenta esta cuestión en F. J. SELLERS BERMEJO et alii, Op. Cit., 1999, apartado 7.2.

47 Ibidem, 1999, Apartado 7.1.

48 Tenemos otros ejemplos coetáneos en las torres octogonales de la cerca de Niebla (Huelva).
} 
sadas, así como cuatro caras del octógono excepto en sus $7.8 \mathrm{~m}$ superiores. Realmente, la base de la exenta es un trapezoide casi cuadrado que mide, comenzando por el lado meridional y en sentido levógiro: $10.44 \times 10.20 \times$ $10.80 \times 10.45 \mathrm{~m}$. Tomando como referencia el terreno a los pies del frente meridional, a 1.08 $\mathrm{m}$ de cota se halla el vértice inferior del plano inclinado sudeste, y se encuentra el del otro plano a $1.65 \mathrm{~m}$ de altura, $40 \mathrm{~cm}$ por encima de una zarpa que recorre toda la cara oriental. A los $3 \mathrm{~m}$ de alzado comienza el trazado octogonal.

Ha sido restaurada en tres ocasiones, la última a cargo del arquitecto Miguel Matas Cascos. En tal intervención se forraron los paramentos de la erosionada parte superior de la torre con nuevas tapias, se dejó al descubierto la cuña triangular del ángulo suroriental y se excavó la cámara, la cual se hallaba colmatada por una capa de dos metros de escombros. Al recuperar el suelo original, se descubrió que la estancia estaba organizada en tres naves paralelas al espigón; es la central de planta rectangular, $2.30 \times 7.50 \mathrm{~m}$, y las laterales con forma de trapecio de $1.70 \mathrm{~m}$ de ancho el occidental y $2.20 \mathrm{~m}$ el oriental. La comunicación entre la principal y las laterales se realizaba mediante un vano para la oeste y dos para la este, de los que uno estaba casi alineado con el de la nave opuesta y el otro se hallaba junto a la entrada a la torre desde el paso albarrano.

Este espigón, aunque se encuentra casi totalmente destruido, conserva restos en sus dos extremos: un muñón, de 14 m de alto, empotrado en la cara norte de la torre y lo que debió ser el arranque desde la muralla. La anchura máxima del espigón no debió sobrepasar 2.40 $\mathrm{m}$. No es posible conocer su trazado exacto, puesto que el vestigio localizado en la muralla ni es perpendicular a la misma, ni está alineado con los restos entestados en la albarrana.
Es posible que el citado elemento estuviese compuesto por dos tramos de diferente orientación, y, a pesar de ser un caso atípico, no resultaría excepcional: el muro que unía la torre del Oro con el recinto inmediato de una de las alcazabas hispalenses también sufría un quiebro en su recorrido ${ }^{49}$. En cualquier caso, la longitud mínima del paso albarrano nunca debió ser inferior a $15.50 \mathrm{~m}$, que es la distancia que media entre la muralla y la cara norte de la torre. El encuentro entre la albarrana y el espigón es realmente peculiar en este caso, pues el enteste no se produce por yuxtaposición de ambos elementos, sino por penetración del paso albarrano en el macizo de la octógona a modo de machihembrado. Tampoco es posible saber si el antemuro discurría estrictamente a pie de muralla o si, contrariamente, acompañaba al paso albarrano en su trazado, como así ocurre en la torre Redonda.

A diferencia de la mayoría de las albarranas del recinto, ésta se edificó íntegramente en tapia sin apreciarse zócalo pétreo de base. De las diecinueve hiladas conservadas, las tres superiores corresponden a los muros de la cámara, las doce siguientes al macizo del octógono, las dos y media situadas por debajo abarcan la transición a planta cuadrada y la primera y media pertenece a la base cuadrada.

Durante la última intervención restauradora se efectuaron unas perforaciones, a modo de catas, que taladraron la exenta diametralmente y a diferentes alturas. A partir de las muestras obtenidas pudo comprobarse que cada hilada de tapia, con un grosor de $2.25 \mathrm{~m}$, se dispuso de forma anular y se rellenó el hueco central resultante con tierra apisonada sin proceso de fraguado ${ }^{50}$. Este sistema permitió levantar la gran mole de la torre con gran celeridad y economía de medios. A pesar de las ventajas que tal método supone, no es posible asegurar su empleo para el resto de macizados en

49 Véase M. VALOR PIECHOTTA, La arquitectura militar y palatina en la Sevilla musulmana, Sevilla, 1991, pp. 236 y 237.

50 Estas conclusiones las ha aportado Miguel Matas Cascos, avalándolas con documentación inédita referente a su intervención en la torre, ejecutada en 1995. 
las torres albarranas de este recinto, de dimensiones notablemente más reducidas ${ }^{51}$.

El grado de conservación de la torre no permite conocer la disposición de la escalera mediante la que se accedía a la terraza almenada ubicada sobre la cámara. Aun así, por analogía con las albarranas de mayores dimensiones $y$, sobre todo, con la otra octogonal conservada, puede afirmarse que la escalera arrancaría del interior de una de las estancias. Es más, según testimonio del referido arquitecto, en la parte de la nave oriental más próxima al espigón existen restos de obra que pudieran corresponder al arranque de dicho elemento.

\section{Torre de la calle Hernando Pizarro}

Emplazada en el ángulo sudeste del recinto. En el plano se marca con el $\mathrm{N}^{\circ}$ । 3. Se localiza $52 \mathrm{~m}$ al este de Torremochada y a $58 \mathrm{~m}$ al noroeste de la de los Pozos. Tradicionalmente no se le ha asignado ningún nombre, por lo que la denominaremos por la calle que le es más próxima. La albarrana, de planta cuadrada, tiene casas adosadas a los lados de su espigón y en todas sus caras excepto en la meridional, que constituye la única libre en su alzado completo. Tal frente arroja una anchura de $6.22 \mathrm{~m}$ en la base y una altura de 1 I.75 $m$ hasta el pretil actual, del que el alfeizar está $0.75 \mathrm{~m}$ sobre el suelo de la terraza; superficie que en un principio debió corresponder al suelo de la cámara desaparecida. Teniendo en cuenta este elemento, podemos calcular la altura original de la torre entre $15.50 \mathrm{~m}$ y $16.40 \mathrm{~m}$ aproximadamente.

El paso albarrano, de $4 \mathrm{~m}$ de longitud, ha debido de sufrir mutilaciones en sus dos caras; mientras que su anchura en la base es de 3.30 $\mathrm{m}$, en el adarve se ve reducida a $2.10 \mathrm{~m}$. Excesiva diferencia para suponer un ataludamiento del paso, sobre todo teniendo en cuenta la escasa altura de éste, $7 \mathrm{~m}$ aproximadamente. En el interior de una vivienda se conserva el arco del espigón, justo en el enteste entre éste y la muralla. Desconocemos su altura pero no así su luz, que es de $1.30 \mathrm{~m}^{52}$.

La torre ha sido restaurada en dos ocasiones: la primera en los años 60 por el arquitecto José Manuel González Valcárcel, que ejecutó una reparación desmoronada parcialmente en la década pasada. Como consecuencia de ello, el arquitecto Miguel Matas Cascos intervino la albarrana forrándola, casi por completo, con nuevas tapias que mantienen la modulación original. Gracias a ello, sabemos que sobre un zócalo ataludado de mampostería, que alcanza los $2.50 \mathrm{~m}$ de altura, se elevaban nueve hiladas de cajones de tapia. Presumiblemente, seis más completarían el bastión primitivo. El espigón también es del mismo material.

\section{Torre del Río}

La torre del Río se halla en el flanco oriental de la cerca. En el plano se indica con el $\mathrm{N}^{\circ}$ 17, y está situada $96 \mathrm{~m}$ al norte de la de los Pozos y $20 \mathrm{~m}$ al sur del arco del Cristo, uno de los primitivos accesos al interior del recinto, al cual defendía. La albarrana, de forma prismática, tiene unas dimensiones de $5.60 \times 6.00$ $\mathrm{m}$ en la base y una altura de $15.80 \mathrm{~m}$ desde el suelo hasta el remate piramidal de los merlones. No conserva el paso albarrano que debió contar con una longitud de 8 a $9 \mathrm{~m}$. En su lugar actualmente existen dos inmuebles, uno de los cuales linda con la torre en tres de sus

5I En una visita realizada por uno de los autores al recinto portugués de Alcácer do Sal, pudo constatarse en la observación de dos torres arruinadas, una cuadrangular de mediano tamaño y otra octogonal con basamento cuadrado de dimensiones similares a Torremochada, cómo el interior de sus macizos estaba constituido por una masa homogénea de tapia. Lo que evidencia que ni siquiera en la edificación de la octógona se empleó el método utilizado en Cáceres. Así pues, mientras no pueda comprobarse similar forma constructiva en otro recinto muminí, deberemos suponer que el caso de Torremochada sería una excepción. Por otra parte, en el sector de la Macarena de las murallas de Sevilla pudo comprobarse que algunas torres fueron levantadas con un método constructivo, si no igual, por lo menos parecido al empleado en Torremochada. De este modo, el material de relleno sin proceso de fraguado del ejemplo extremeño es, en el caso hispalense, sustituido por un hormigón menos consistente que la tapia envolvente. Léase, J. M. VARGAS JIMÉNEZ et alii, "Las murallas: intervenciones arqueológicas municipales", Sevilla almohade, Sevilla-Rabat, 1999, p. 58.

52 Hemos podido comprobar la subsistencia del vano consultando el citado M. MATAS CASCOS, Plano de análisis de las murallas de Cáceres, escala 1:250, plano $\mathrm{N}^{\circ} 106$. 
cuatro frentes. Reseñemos que las cotas aportadas están medidas a partir de lo que parece ser la rasante original de la albarrana en su cara más alejada de la muralla.

La torre arranca con un zócalo de $2.20 \mathrm{~m}$ de altura, ejecutado en mampostería y sillarejos graníticos en las esquinas. Esta obra es apreciable solamente en el ángulo este de la construcción, puesto que el resto de la misma está parcialmente oculto por edificaciones anexas. En la cara norte de la torre, la única liberada totalmente de casas adosadas, el enrasamiento de la calle cubre la cara exterior del mencionado elemento. Sobre este basamento se levanta un macizo de tapia observable exteriormente hasta $9.00 \mathrm{~m}$ de altura. La obra de encofrado abarca ocho filas de cajones de 80 a $85 \mathrm{~cm}$ de altura cada una; la inferior es más prominente que las restantes. Todas las caras estaban cubiertas por un enlucido ocre rojizo y los límites horizontales entre las hiladas marcados por una cinta de cal de unos $5 \mathrm{~cm}$ de altura y I cm de espesor. No se observan, sin embargo, estas fajas en los límites verticales entre diferentes cajones de una misma fila, característica sí identificada en el resto de la muralla almohade excepto en la torre de los Pozos, cuyo tratamiento superficial es similar al de esta albarrana.

Las esquinas de la torre en los dos últimos niveles de tapia están talladas para asentar la cadena de sillares graníticos que asciende hasta la base de los merlones. Desde $9.00 \mathrm{~m}$ hasta los $15.80 \mathrm{~m}$ de cota total, el exterior de la albarrana está ejecutado con mampostería reforzada con los mencionados sillares esquineros. Esta intervención es, sin duda, una reforma posterior a la definitiva conquista leonesa.

Sondeos electromagnéticos realizados experimentalmente parecen indicar que el núcleo de la obra de encofrado alcanza, como mínimo hasta $12.00 \mathrm{~m}$ de altura ${ }^{53}$. Así pues, gran parte de la labor de mampostería actuaría como funda de un núcleo de tapia, no visible, de unas tres o cuatro filas. Si se suman las hiladas ocultas a las visibles se obtiene un total de once o doce niveles de cajones. Relacionando esta modulación con otras comprobadas en otras torres de la cerca se podría aventurar la suposición de que el macizo de hormigón conservado alcanza hasta el suelo de la cámara que debió de tener la albarrana en época almohade.

El acceso a la terraza de la torre se realiza desde la segunda planta de la casa colindante a través de una empinada escalera cuyo tramo superior atraviesa parte del macizo. La terraza cuenta con un parapeto perimetral rematado con merlones en tres de sus frentes. En el cuarto, el más próximo a la muralla, el pretil está sobreelevado ocupando el lugar correspondiente a los referidos elementos prismáticos.

\section{Supuesta torre meridional de la calle Caleros}

Estaría situada en el flanco oriental de la cerca, entre la exenta del Río y la septentrional de la calle Caleros, y próxima al arco del Cristo. Aparece en la planimetría con el $N^{\circ} 18$. Esta supuesta torre viene reflejada en diversos croquis de la muralla publicados por diversos investigadores, quienes se limitan a referirla sin atribuirle siquiera denominación ni aportar ninguna referencia documental que explique su existencia ${ }^{54}$. Posiblemente, tal justificación haya querido legitimarse en la suposición de que cada puerta del recinto debiera de estar protegida por una pareja de albarranas. Precisamente, es en este acceso donde tendríamos menos posibilidades de adjudicar con éxito tal esquema; puesto que el semicodo que experimenta el arco del Cristo hace que la presunta torre que nos ocupa no sea tan imprescindible. Pero, por otro lado, los $110 \mathrm{~m}$ que separan la exenta del Río de la septentrional ya

53 No existe documentación escrita acerca de tales prospecciones. Únicamente hemos dispuesto del testimonio verbal de Miguel Matas Cascos.

54 Véase F. BRAVO Y BRAVO, Op. Cit., 28 Mayo 1975, p. 9, M. M. LOZANO BARTOLOZZI, Op. Cit., 1980, p. 70; así como G. RODRÍGUEZ CEREZO, Op. Cit,, 1988, p. 105 
referida constituyen una distancia tan excesiva que justificarían la ubicación de un bastión intermedio. En conclusión: efectivamente pudo situarse una albarrana en este tramo, pero no necesariamente destinada a batir el acceso, sino para defensa del lienzo.

\section{Torre septentrional de la calle Caleros}

Situada en el frente oriental del recinto amurallado (Fig. 9). En el plano se refleja con el $\mathrm{N}^{\circ}$ 19 , y está ubicada $110 \mathrm{~m}$ al norte de la del Río y $33 \mathrm{~m}$ al sur de la semicilíndrica. También hemos encontrado el topónimo de El Lobo para referirse a esta torre ${ }^{55}$. A pesar de haber sido incomprensiblemente ignorada por algún autor ${ }^{56}$, su mole descuella sobre las edificaciones que se le adosan en todos sus frentes. En el espacio comprendido entre la muralla y la albarrana se emplaza una casa con sus muros exteriores coplanarios con las caras septentrional y meridional de la torre. Esta casa ocupa también el espacio correspondiente a la desaparecida cámara, y remata el conjunto con un tejado a dos aguas; incluso la parte superior del macizo de tapia fue vaciada para generar algunas de las estancias de la vivienda.

Gracias a un minucioso análisis de las fuentes gráficas, principalmente fotografías y planos, podemos ofrecer medidas bastante aproximadas del bastión. La planta es un rectángulo de $6.70 \times 5.40 \mathrm{~m}$, cuyos lados cortos miran a norte y sur. Se puede apreciar la falta de perpendicularidad de la exenta, orientada ligeramente a sudeste, puesto que los lados referidos describen ángulos de $99^{\circ}$ respecto a la muralla. La torre, excepto en la cara más cercana al lienzo, se libera de las construcciones adosadas a una altura media de $6 \mathrm{~m}$, y alcanza la cota máxima conservada a $11.80 \mathrm{~m}$, coincidiendo con el suelo de la cámara. Teniendo en cuenta este elemento, y los pretiles y mer- latura que lo coronaron, la albarrana debió de llegar a los 17.80 m aproximadamente. La longitud del paso albarrano no debió de ser superior a $4 \mathrm{~m}$. En una de las fotografías analizadas se observa un elemento que podría ser interpretado como pretil del adarve del antemuro, que se encontraría a unos $6.40 \mathrm{~m}$ respecto a la hipotética rasante exterior. El posible parapeto es coplanario de la cara septentrional de la torre, lo que permite suponer que, al ser el espigón tan corto, estaría flanqueado a cada lado por sendos tramos de antemuro.

La exenta fue construida en tapia de hormigón de cal, de la que se pueden rastrear hasta siete hiladas que median entre las casas adosadas y el suelo de la cámara arrasada. En las magnitudes dadas encajaría la siguiente distribución hipotética, pero fundada, de los encofrados. De un total de diecisiete, seis corresponderían a la estancia, parapeto y merlones, y once al macizo levantado sobre una probable base de sillares o mampostería. Tal modulación coincidiría con la de las torres del Horno y del Aver. La altura de cada hilada parece que oscila entre 0.85 y $0.90 \mathrm{~m}$.

\section{Torre del Aire}

En el plano se marca con el $N^{\circ} 20$. Está situada en el flanco septentrional de la cerca, $37 \mathrm{~m}$ al oeste de la semicilíndrica y $62 \mathrm{~m}$ al este de la del socorro. La torre y la zona adyacente hasta la muralla están englobadas en la actualidad dentro de una edificación muy reformada en los últimos siglos. Recientes trabajos realizados en este inmueble han permitido identificar con exactitud la estructura militar almohade ${ }^{57}$. De este modo, se conserva el alzado completo de la albarrana hasta el pretil del terrado (con una altura total de $13.50 \mathrm{~m}$ ), el machón de fábrica del espigón, que poseía dos vanos, y el basamento de la torre de flanqueo

55 Refiere esta denominación M. MATAS CASCOS, Op. Cit., 1996, pp. 269 y 270.

56 En el plano adjunto a su artículo, Leopoldo Torres Balbás elude la representación de esta albarrana. Véase L. TORRES BALBÁS, Op. Cit., 1948, plano de la cerca almohade.

57 Consisten en la reforma y restauración del edificio para su uso como vivienda particular, dirigidas por el arquitecto D. José M. Rodríguez Puebla. Un estudio completo sobre esta intervención será publicado próximamente por dicho técnico. 
donde entestaba. La base de la albarrana es un trapezoide tendente al rectángulo, que mide, comenzando por el lado norte $y$ en sentido levógiro: $7.60 \times 7 \times 8.50 \times 7.10 \mathrm{~m}^{58}$. En su frente este se ha podido estudiar su basamento formado por sillares de granito reaprovechados, en ocasiones dispuestos a soga y tizón. Similar material encontramos en la base del espigón, aunque combinado con mampostería sobre la que se alzan las tapias. Sobre la piedra enfoscada se practicaron líneas incisas simulando sillería. Con relación al cubo, se reconocen en su cara norte cuatro hiladas de sillería formando zarpa, y otras dos superiores del alzado.

Como se ha referido, la estructura de la torre albarrana se encuentra muy alterada, no obstante es posible suponer su estado primitivo. Su cámara, de planta cuadrada, no aparenta abovedamiento, de modo que planteamos su cubrición mediante un forjado lignario. Esta solución, aunque no identificada en el resto de la cerca cacereña, no es extraña en la poliorcética almohade, como comprobamos en alguna torre de Alcácer do Sal y, tal vez, en alguna reformada de la alcazaba de Badajoz. La altura de esta habitación se reduciría a la correspondiente a tres tapias, sobre las cuales se elevaba la hilada del pretil. En él se conservan cegados los huecos abocinados de las saeteras, dos por frente excepto en el que mira al espigón.

\section{Torre del Socorro}

Se sitúa en el frente norte de la cerca. En el plano aparece reflejada con el $\mathrm{N}^{\circ} 21$, y se emplaza $62 \mathrm{~m}$ al oeste de la del Aire y $28 \mathrm{~m}$ al este de la del Rey. También se la conoce por torre de los Pobres, de Roco, y de la puerta de Coria. Como la de Bujaco, sufrió profundas transformaciones desde su conquista definitiva de la plaza. Primero fue forrada, y posteriormente ahuecada en sucesivas reformas. De este modo, es poco probable que subsistan restos de las tapias originales. La albarrana es, hoy en día, un prisma que mide $7.15 \mathrm{~m}$ de lado por
I3.70 m de altura hasta el inicio de la cubierta. Se encuentra separada 11.80 m de la muralla y no conserva vestigios del espigón.

\section{Torre del Rey}

Localizada en el flanco septentrional del recinto. En el plano está indicada con el $\mathrm{N}^{\circ} 22$, se sitúa $28 \mathrm{~m}$ al oeste de la del Socorro y 37 $\mathrm{m}$ al este de la de la Basura. Junto con la vecina torre del Socorro formó parte del dispositivo defensivo que protegía la puerta de Coria. Al igual que la de Bujaco y la del Socorro, fue muy reformada mediante el forrado del macizo de tapia y substitución de la cámara. La base es un rectángulo, casi cuadrado, de $9 \times 9.25 \mathrm{~m}$, con sus lados menores paralelos a la muralla. Alcanza una altura total de $14.50 \mathrm{~m}$ hasta su coronación actual. El espigón medía aproximadamente $17 \mathrm{~m}$.

\section{Torres de flanqueo}

\section{Cubo de la calle Arco de España}

Indicado en el plano con la letra A. Se emplaza en el frente occidental del recinto, $15 \mathrm{~m}$ al sur de la albarrana de la Basura y $43 \mathrm{~m}$ al norte de la de Bujaco, sobre un ángulo de $137^{\circ}$ que experimenta la muralla, justificándose así la ubicación de un bastión defensivo en ese punto. Sus vestigios se hallan inmersos totalmente dentro del caserío adyacente, por lo que únicamente puede detectarse su presencia a través de planos ${ }^{59}$. Parece ser que sobresalía unos $4 \mathrm{~m}$ respecto de la muralla, y su cara oeste arrojaba una anchura de $6 \mathrm{~m}$. Estas dimensiones son similares a las del cubo del Olivar.

\section{Torre de los Púlpitos}

En el plano se marca con la letra B. Se encuentra en el flanco occidental del recinto, $35 \mathrm{~m}$ al sur de la de Bujaco y $32 \mathrm{~m}$ al norte de la de la Yerba. Sus caras sur, oeste y norte

58 Medidas obtenidas de F. J. SELLERS BERMEJO et alii, Op. Cit., 1999, apartado 5.I.

59 Véase M. MATAS CASCOS, Plano de análisis de las murallas de Cáceres, Cáceres, escala I:250, plano № 61. 
arrojan una anchura de 4.12, 4.04 y 3.76 m respectivamente. Presenta basamento de sillería. Las tres primeras hiladas, dado el tamaño de los sillares y su aparejo, no parecen pertenecer al mismo momento constructivo que el resto de la torre y son, por tanto, anteriores.

Todos los autores fechan su construcción en los siglos XIV o XV ${ }^{60}$, relacionando incluso su edificación con la apertura, a escasos metros, de la llamada puerta Nueva ${ }^{61}$. Basándonos en la ubicación de la torre, prácticamente equidistante de las de Bujaco y Yerba, en sus dimensiones en planta, y en la disposición constructiva de su parte inferior, creemos que en este lugar debió de emplazarse un cubo de origen islámico.

\section{Supuesta torre del foro de los Balbos}

Viene reflejada en la planimetría como $C$. Situada en el flanco occidental del recinto, entre las torres de la Yerba y el Horno. Actualmente no queda ningún vestigio de esta torre, sin embargo, abundante documentación fotográfica anterior a la demolición del tramo en 1930 nos permite especular acerca de su existencia. En tales imágenes aparece una construcción estilizada de tapia que se adelanta y sobrepasa en altura al lienzo anexo ${ }^{62}$. Además, su situación equidistante entre las exentas de la Yerba y del Horno, parece reforzar tal hipótesis.

\section{Cubo de la calle adarve del Padre Rosalío}

Se indica en el plano con la letra D. Está ubicado en el flanco occidental del recinto, $54 \mathrm{~m}$ al sur de la albarrana del Postigo de Santa Ana, y $20 \mathrm{~m}$ al norte de la del Aver. Lo nombramos por la calle más cercana, a pesar de hallarse ésta intramuros. A causa de la imposibilidad de acce- der al adarve y base del cubo, las medidas ofrecidas son aproximadas ${ }^{63}$ (Figs. 3 y 10).

El inicio de la torre puede encontrarse entre 3 y $4 \mathrm{~m}$ por encima de la calle del Postigo, hacia la cual se orienta. Considerando la rasante del terreno como nivel de referencia, alcanza en el remate del pretil una altura aproximada de $9.90 \mathrm{~m}$. Con los merlones debió de llegar más o menos hasta $10.80 \mathrm{~m}$. El bastión sobresale poco más de $2 \mathrm{~m}$ respecto del lienzo al que se adosa. La anchura del frente oeste, paralelo a la muralla, sobrepasa los $4 \mathrm{~m}$. La terraza se eleva, sobre el adarve del muro, en una altura correspondiente a dos cajones de tapia, salvándose la diferencia mediante unos escalones practicados en el macizo del cubo, para no entorpecer el tránsito en el mencionado adarve. Gracias a las huellas conservadas en los pretiles de la torre ${ }^{64}$, se pueden restituir el número y la ubicación de sus merlones. Todos tenían planta rectangular, emplazándose tres sobre la cara de poniente, hasta las esquinas, y dos sobre las laterales, norte y sur. En el centro del parapeto de la cara occidental, se conservan los restos de una saetera con derrame al interior, que se completaría en el merlón central desaparecido. De este modo, tal hueco no coincidía con ninguna hilada de tapia, sino que estaba a caballo entre la del pretil y la del prisma situado encima.

La parte inferior de la torre está construida mediante sucesivas filas de sillares graníticos reaprovechados, de los que algunos muestran talla almohadillada romana. El aparejo es bastante irregular e improvisado, y se ubican las mejores y mayores piezas en las esquinas. Únicamente en dichas aristas, entre 3,50 y $5.50 \mathrm{~m}$ de cota, es donde se mantienen los grandes sillares de granito, aparejándose el interior de

60 Consúltese M. M. LOZANO BARTOLOZZI, Op. Cit., 1980, p. 67, y G. RODRÍGUEZ CEREZO, Op. Cit., 1988 , p. 102.

6I Refiere esta cuestión C. CALLEJO SERRANO, Op. Cit., 1972, p. 33.

62 Consúltese, N. DÍAZ y PÉREZ, España. Sus monumentos y artes. Su naturaleza e historia, Barcelona, I887, p. 735; J. BLÁZQUEZ MARCOS, Por la vieja Extremadura: Guía Artística de la provincia de Cáceres, Cáceres, 1929, Lám. IV, Número 5; J. R. MARCHENA PÉREZ, Cáceres en el pasado, Cáceres, 1984, p. 27.

63 El nivel de error es aceptable, puesto que las medidas propuestas han sido calculadas tras la consulta de varios planos y abundante documentación fotográfica.

64 Tales huellas no son más que los rebajes curvos que marcan cada almena o hueco entre merlones. 
las caras del cubo con mampostería, predominantemente cuarcítica. Toda esta obra está trabada con abundante mortero de cal. Los 4.40 m superiores del bastión están constituidos por cinco hiladas de tapia, de las que cuatro pertenecen al macizo y la última al parapeto.

El zócalo pétreo de la torre presenta evidentes similitudes, en cuanto a dimensiones y aparejo, con los vestigios de los cubos embutidos en los espigones de las albarranas del Horno y del Aver. Esto nos induce a suponer que el que nos ocupa debió de erigirse en la comentada fase islámica, anterior a la gran reforma de los Unitarios en que se recrecería con la obra encofrada.

\section{Cubo occidental de la calle Cornudillas}

En el plano se señala con la letra E. Está emplazado en el frente meridional del recinto, $21 \mathrm{~m}$ a levante de Redonda y unos $33 \mathrm{~m} \mathrm{a}$ poniente de la supuesta albarrana de la calle Cornudillas. Su arranque se encuentra al mismo nivel que el adarve del antemuro, aproximadamente $6 \mathrm{~m}$ por encima de la mencionada calle. La terraza del cubo se eleva $6.20 \mathrm{~m}$ sobre la base, y está situada a la misma altura que el adarve del lienzo al que se adosa. En planta, el bastión mide $3 \mathrm{~m}$ de anchura por $3 \mathrm{~m}$ de profundidad. A causa de los sucesivos parches y refacciones que ha sufrido a lo largo de los siglos, es imposible reconocer en sus paramentos ningún elemento constructivo original.

\section{Cubo oriental de la calle Cornudillas}

Aparece reflejado en el plano con la letra $F$. Se sitúa en el flanco meridional de la cerca, unos $20 \mathrm{~m}$ al este de la supuesta albarrana de la misma calle, y a una distancia indeterminada al oeste de la de Mari Lucas. La torre se encuentra libre de casas adosadas en la parte superior de sus caras este y sur, y se puede contemplar toda su alzado en la mitad occidental del frente meridional (Lám. 6). El nivel de la calle Cor- nudillas se encuentra aproximadamente $3.60 \mathrm{~m}$ por debajo del patio inmediato ${ }^{65}$, al que consideramos como cota de referencia, desde el que se puede ver el alzado del cubo. Éste se eleva $9.50 \mathrm{~m}$ hasta el borde del pretil, que se halla cercenado en sus últimos $30 \circ 40 \mathrm{~cm}$. Incluyendo los merlones, el bastión debió de alcanzar una altura total de más de $10.50 \mathrm{~m}$. En planta, la torre sobresale $2.89 \mathrm{~m}$ respecto de la muralla, mientras que la cara paralela a ésta arroja $3.90 \mathrm{~m}$ de ancho; su terraza se encuentra a una cota de $9.10 \mathrm{~m}$, un metro por encima del adarve del lienzo al cual se adosa la torre. De aquél subsiste un tramo de $14 \mathrm{~m}$ de longitud que avanza a oriente. El desnivel entre ambas superficies se salva mediante tres escalones practicados en el macizo del cubo, para así no interrumpir el tránsito en el adarve de la muralla. A pesar de estar perdida la parte superior del parapeto y merlones, es posible suponer para estos últimos un número y disposición idénticos a los observados en el cubo D, de similar morfología y dimensiones que el que nos ocupa.

La parte inferior de la torre está constituida por un zócalo pétreo formado por seis hiladas de sillares graníticos reaprovechados, sin duda, de anteriores construcciones. Por una parte, nos encontramos con un aparejo de huidiza isodomía, en el que casi coinciden las llagas verticales de hiladas contiguas. Por otro lado, se detecta un enllagado de grosores muy irregulares donde proliferan trozos de cuarcitas, pizarras y fragmentos de ladrillo, que tratan de calzar sillares y rellenar algunos de sus desgastados ángulos. En la sexta hilada se aprecia un fragmento de fuste granítico dispuesto transversalmente, de tal forma que se percibe la circunferencia de su base. Entre las cotas 2.90 y 3.90 m, los sillares son sustituidos por un tramo de mampostería cuarcítica, con refuerzos en las esquinas de mampuestos ligeramente más regulares y mayores. A partir de este nivel, se levantan seis hiladas de tapia hasta la terraza del cubo. De la séptima, que forma parte del pretil, sólo resta la mitad inferior.

65 Este desnivel puede explicarse por la existencia del antemuro, de tal forma que el adarve de éste debió de coincidir en altura con la rasante del patio actual. 


\section{Cubo del olivar ${ }^{66}$}

Se indica con la letra G. Está emplazado en el flanco oriental de la cerca, $25 \mathrm{~m}$ al norte de la albarrana de Hernando Pizarro, $25 \mathrm{~m}$ a poniente de la de los Aljibes, y $30 \mathrm{~m}$ a suroeste de la de los Pozos. En planta, el cubo sobresale poco más de $4 \mathrm{~m}$ respecto de la muralla, mientras que la cara paralela a ésta mide $6.10 \mathrm{~m}$ de ancho. Esta torre nace a nivel del adarve del antemuro, que se eleva una media de $1.50 \mathrm{~m}$ sobre el terreno circundante. En este sector, las casas adosadas a la muralla desde el interior, y que invaden su paso de ronda, impiden comprobar con certeza si la terraza de la torre se encuentra sobreelevada respecto del adarve del lienzo adosado; aunque parece que así es.

En una fotografía de los años 50, o primeros 60 del siglo $X X$, se puede apreciar el estado de conservación del cubo con anterioridad a la primera de las dos restauraciones que ha sufrido en tiempos recientes, la del arquitecto José Manuel González Valcárcel (Fig. II). En aquella imagen se puede ver el zócalo pétreo que ha perdido totalmente su revestimiento hasta una cota de $3 \mathrm{~m}$, y las esquinas casi hasta los $4.85 \mathrm{~m}$ de altura, que es donde comienza la obra encofrada. El revestimiento original conservado está ejecutado con mampuestos, ubicándose los mayores y más regulares en la parte inferior de lo subsistente. El análisis de esta fotografía y de los cubos D y F, análogos a éste, nos ha hecho suponer que tales superficies descarnadas estaban forradas por un aparejo de sillares graníticos reaprovechados que, en un momento indeterminado, fueron expoliados para ser nuevamente reutilizados en otras construcciones. En la obra dirigida por Valcárcel se reconstruyeron las partes perdidas con mampostería, y se parchearon toscamente las hiladas de tapia dispuestas sobre el zócalo pétreo.
Tan poco afortunada fue la restauración de los encofrados que, a principios de los 90, debió acometerse una nueva intervención, esta vez a cargo del arquitecto Miguel Matas Cascos, en la que fue necesario consolidar lo que subsistía forrándolo con nuevas tapias que trataron de respetar la modulación original de las hiladas. Así pues, parece ser que eran cinco el número de éstas que se elevaban hasta la terraza.

\section{Cubo semicilíndrico}

Se emplaza en el ángulo nordeste del recinto. En el plano está indicada con la letra $\mathrm{H}$. Se ubica $34 \mathrm{~m}$ al norte de la septentrional de la calle Caleros y $37 \mathrm{~m}$ al este de la del Aire. Realmente todos los autores consultados la denominan torre Redonda ${ }^{67}$, adoptando el mismo nombre que recibe la octogonal del ángulo suroeste. Para que no haya dos homónimas, y atendiendo a criterios formales, le hemos adjudicado un topónimo diferente a ésta por considerarla menos significativa.

La torre conservada en la actualidad, como algunos investigadores han señalado, es improbable que pertenezca a la fase almohade de la cerca ${ }^{68}$, pudiéndose encuadrar dentro de dos periodos diferentes. Uno, comprendido entre | 65 y | |74, en que el enclave es ocupado sucesivamente por portugueses y leoneses, y otro, iniciado a partir de 1229 con la definitiva conquista leonesa. La primera posibilidad implicaría que los Unitarios no habrían ejecutado reformas en el ángulo nordeste, considerando el buen estado de la torrecilla y la suficiencia de las defensas naturales del sector. Decantándonos por la segunda, podemos suponer que la albarrana almohade se habría deteriorado rápidamente, y que fue sustituida por la actual semicilíndrica. Únicamente, una intervención arqueológica o nuevos datos cronísticos podrían ayudar a dilucidar la cuestión.

\footnotetext{
66 Le hemos adjudicado tal denominación por hallarse en un olivar limitado por la albarrana de Hernando Pizarro, la muralla y el muro meridional del conjunto de los Pozos.

67 Así lo hacen F. BRAVO Y BRAVO, Op. Cit., 28 Mayo 1975, p. 9; M. M. LOZANO BARTOLOZZI, Op. Cit., 1980, p. 69; y G. RODRÍGUEZ CEREZO, Op. Cit., 1988, p. 105.

68 Léase a G. RODRÍGUEZ CEREZO, Op. Cit., 1988, p. 105, así como F. VALDÉS FERNÁNDEZ, Op. Cit., 1999 , p. 246, nota 25.
} 


\section{Cubo de "Cerrillo"}

En el año 1974, el catedrático Enrique Cerrillo Martín de Cáceres inspeccionó unos vestigios arqueológicos que, a su juicio, forman parte de un cubo que se localiza en el frente septentrional de la cerca, a escasos metros del espigón de la torre de la Basura. En el plano se indica con la letra I. Puesto que los restos estaban enterrados, y en ese estado permanecen, no se pudo tomar ningún dato referente a sus dimensiones ${ }^{69}$. Solamente nos queda el testimonio del citado profesor y unas fotografías que reflejan lo que podía verse, en las que se aprecian unas hiladas de sillares graníticos, estando almohadillados los de la inferior. Dos de las piezas de las filas superiores tienen grabada una inscripción con caracteres latinos.

\section{Un caso excepcional: la Torre de los Pozos y su epígrafe almohade}

\section{ANÁLISIS MORFOLÓGICO}

Este conjunto defensivo se ubica en el flanco oriental del recinto. Está integrado, entre otros lienzos, por la torre de los Pozos, la torre Coracha y la torre de los Aljibes, indicadas en el plano con los números 16, 15 y 14 respectivamente (Fig. II). La principal de ellas es la que da nombre al bastión, y se encuentra 58 m a nordeste de la exenta de la calle Hernando Pizarro y $96 \mathrm{~m}$ al sur de la del Río.

Es un baluarte de planta trapezoide, casi rectangular, y proyectado hacia el exterior de la cerca, aproximándose a un pequeño arroyo conocido como rivera del Marco (Lám. 7). Su frente oeste es un tramo de $19 \mathrm{~m}$ de la propia muralla de la ciudad. El lado norte es un paso albarrano de $26 \mathrm{~m}$ de longitud que acaba en la llamada torre de los Pozos o del Gitano. El oriental es un muro de $14.50 \mathrm{~m}$ de largo casi paralelo a la muralla y que arranca del frente sur de la citada albarrana. Cierra la cara meridional del patio un lienzo de $31 \mathrm{~m}$ prácticamente paralelo al espigón de la exenta. Si el ángulo nordeste del conjunto está ocupado por la torre de los Pozos, el sudeste lo está por otra torre albarrana, llamada de los Aljibes, unida al baluarte que nos ocupa mediante un pequeño paso albarrano de solamente $2.35 \mathrm{~m}$ de longitud. Esta exenta defendía un pequeño vano o postigo abierto en la zona adyacente del lienzo este. Actualmente esta torre se encuentra mutilada en sus $8.40 \mathrm{~m}$ superiores, lo cual puede llevar a confundir a veces su espigón, que sí se conserva, con la torre en sí. Tanto la terraza de la exenta de los Pozos como el adarve de la muralla se hallan prácticamente a la misma cota. Sin embargo, el adarve de los muros este y sur del patio se encuentran $4.70 \mathrm{~m}$ por debajo de aquellos. El nivel del adarve del espigón de la del Gitano se sitúa en el tramo conservado, el más cercano a la torre, a $1.90 \mathrm{~m}$ por encima de los mencionados muros de levante y meridional. Las diferencias de cotas se deben a la inclinación del terreno y a la ubicación de la torre de los Pozos sobre un gran espolón rocoso que, pese a seguir la pendiente donde está enclavado, está unos metros más elevado.

Actualmente, el interior de este baluarte se encuentra totalmente colmatado de tierra hasta el nivel del adarve de los lienzos sur y este, y convertido en un huerto. El tramo de la muralla urbana está suplantado por unas casas, así como los $17.50 \mathrm{~m}$ del espigón de la torre de los Pozos más alejados de la misma. La parte conservada de dicho paso albarrano mide 8.50 $\mathrm{m}$ de longitud y tiene una anchura de $1.75 \mathrm{~m}$ en lo más alejado de la torre y $2.40 \mathrm{~m}$ en el enteste con la misma. Este encuentro no se produce en el centro de la cara oeste de la exenta, sino junto al ángulo norte de la cara, de tal manera que las fachadas septentrionales del espigón y de la albarrana son coplanarias. Más adelante se comentarán las posibles causas de esa excepción morfológica. Casi en

69 Según afirma Enrique Cerrillo, tuvo que introducirse por un angosto agujero y descender un par de metros para poder inspeccionar los restos y obtener fotografías, las cuales ha tenido la amabilidad de mostrarnos. 
la unión de la torre y su paso, pero $4.70 \mathrm{~m}$ inferior, se produce otro encuentro, esta vez con el antemuro.

Es complicado hacer un análisis formal del espigón conservado, pues aparece su adarve invadido por construcciones parásitas. Pese a ello, en su frente norte puede atisbarse sobre el pretil cuatro merlones parcialmente mutilados. Por el contrario, sorprende ver en su cara de mediodía cómo en la altura correspondiente a la merlatura, el muro no presenta discontinuidad. Pareciera que sobre el parapeto se elevara otro ocupando el sitio de los merlones.

La torre de los Pozos posee un volumen troncoprismático, y su planta, medida en la terraza, es un trapezoide tendente al rectángulo de $7.22 \times 5.02 \times 7.45 \times 5.75$ m nombrados en sentido levógiro comenzando por el lado septentrional. Alcanza una altura máxima de $14 \mathrm{~m}$ sobre el espolón cuarcítico sobre el que asienta. Esta magnitud sería $0.90 \mathrm{~m}$ mayor si se hubiesen conservado los merlones. Aun así, éstos se podrían restituir en todos sus frentes, excepto en el oeste, gracias a las huellas de sus arranques. Así, la cara oriental tuvo cuatro merlones, todos de planta rectangular, que ocupaban toda la anchura de la fachada. Las caras norte y sur también poseían cada una otros cuatro de estos elementos prismáticos pero no abarcaban toda la anchura de los respectivos frentes, pues los ángulos noreste y sudeste de la torre ya estaban ocupados por los merlones esquineros de la citada cara este. Eso sí, los ángulos noroeste y suroeste sí estaban coronados por merlones correspondientes a las fachadas meridional y septentrional respectivamente. En consecuencia, es posible suponer que sobre el pretil oeste, por ser el más corto, debieron de elevarse dos prismas grandes o tres más pequeños.

En un principio, el ingreso a la cámara desde el exterior se realizaba por el paso albarrano desde poniente. Hoy, por estar condenada esa entrada, hay que acceder a través del vano arcuado que comunica la torre con el adarve del lienzo de levante del baluarte, el cual, recordemos, está colmatado y convertido en un huerto al que se acomete a través de la vivien- da que suplanta el tramo de lienzo de la ciudad. El suelo de la estancia de la torre está elevado sobre el mencionado adarve una altura correspondiente a dos hiladas de tapia, $1.90 \mathrm{~m}$ en este caso, salvándose la diferencia mediante una escalera de nueve escalones cuya mitad inicial transcurre al aire libre y la segunda bajo el cañón del vano. Éste alcanza sobre el primer escalón que cobija, el quinto de la escalera, una cota de $3.10 \mathrm{~m}$. Esa magnitud queda reducida a $2.20 \mathrm{~m}$ tomada sobre el suelo de la cámara. Sin embargo, serán invariables la profundidad y la anchura del acceso, estimadas en 1.12 y $0.84 \mathrm{~m}$ respectivamente.

Al igual que la torre, la planta de la cámara tiene forma trapezoide tendente al rectángulo, y mide, comenzando por el lado de levante $y$ en sentido levógiro, $3.37 \times 3.36 \times 3.05 \times$ $3.36 \mathrm{~m}$. En el centro de la estancia hay una columna de granito de $1.84 \mathrm{~m}$ de altura, formada por tres tambores, de la que arrancan cuatro arcos perpendiculares a las paredes que los reciben, los cuales alcanzan en la clave una elevación media de $2.70 \mathrm{~m}$ sobre el suelo de la habitación. Se generan así cuatro espacios similares cubiertos por bóvedas de arista. La distancia entre las claves de la cámara y la superficie de la terraza que hay encima es de 0.82 $\mathrm{m}$. En la zona norte de la pared de poniente hay un vano adintelado, de $0.88 \mathrm{~m}$ de ancho y $1.90 \mathrm{~m}$ de alto, que da acceso a la escalera que, embebida en el muro oeste de la torre, asciende hasta la esquina suroeste $y$, tras una meseta, quiebra en ángulo recto hacia levante y sale a la terraza (Lám. 8).

El muro que cierra a levante el baluarte se eleva, en su mitad septentrional, sobre parte del mismo espolón cuarcítico que sirve de base a la torre de los Pozos. Tiene en su extremo norte una cota de $9.20 \mathrm{~m}$ desde la roca hasta la merlatura. Sin embargo, en el extremo sur desaparece la cuarcita y cimienta directamente sobre un terreno más bajo, alcanzando así el lienzo una altura máxima de 13.80 m desde el suelo hasta los merlones. Es en esta parte dónde se localiza el vano o postigo, que daba entrada al baluarte desde el exterior. Posee bóveda de medio cañón rampante, $1.25 \mathrm{~m}$ de luz, $3.60 \mathrm{~m}$ de altura y $2.25 \mathrm{~m}$ de profundidad, 
la misma que la anchura del muro que perfora. El fondo del acceso está cegado por el potente relleno ya citado. Aun así, es posible apreciar cómo la pared septentrional del pasadizo se prolonga más allá del grosor del muro y se pierde en el macizo. De este modo, parece que el cañón desembocaba hacia un primer corredor, de unos $2.50 \mathrm{~m}$ de ancho, probablemente sin cubierta.

Actualmente rematan este muro seis merlones, de los que el correspondiente al extremo meridional tiene planta en forma de $L$ por estar coronando el encuentro entre este lienzo y el paso albarrano de la torre que defendía el postigo. Los otros cinco elementos prismáticos tienen planta rectangular y miden, aproximadamente, I m de longitud, estando separados por intervalos de $2 \mathrm{~m}$. Una fotografía de 1887 demuestra que en un principio cada uno de estos espacios estuvo ocupado por un merlón de las mismas dimensiones que los subsistentes, siendo los intervalos originales de $0.50 \mathrm{~m}^{\text {de longitud }}{ }^{70}$.

Siguiendo con nuestra descripción del conjunto, apuntemos que no es posible conocer las dimensiones exactas de la torre de los Aljibes debido a que se encuentra mutilada su parte superior y su cara septentrional. Su base se halla rodeada de construcciones parásitas y cimentada sobre una fuerte pendiente. A pesar de ello, sí es posible establecer la altura de la cara oeste del muñón, conservado en $3 \mathrm{~m}$ aproximadamente. Si a este dato añadimos la distancia desde ese punto al adarve del espigón, tenemos que la altura de esta albarrana en su cara de poniente, desde el suelo actual hasta el nivel del adarve, debió de superar los $9 \mathrm{~m}$. Considerando que la base de la torre, por la cara de levante, se sitúa como mínimo $4 \mathrm{~m}$ por debajo de la opuesta, la exenta alcanzaría en su fachada principal una altura mínima de I 3 m hasta el suelo de su paso albarrano. Así, estos datos parecen indicar que la de los Aljibes pudo carecer de cámara, pues su elevación habría resultado excesiva. Tengamos en cuenta que las torres más elevadas se encuentran en el flanco occidental de la fortificación y levantadas siempre sobre pendientes más suaves.

En cuanto a sus dimensiones en planta, comentemos que es un rectángulo con los lados mayores paralelos al lienzo que contiene el postigo, de los que no será posible conocer su longitud exacta hasta la realización de una intervención arqueológica. A pesar de ello podemos intentar aproximar algunas medidas. La cara oeste mide $3.50 \mathrm{~m}$ desde su extremo sur hasta el encuentro con el paso albarrano que arroja una anchura de $2 \mathrm{~m}$. Como el frente norte de la torre está perdido, al menos en superficie, se pueden contemplar dos posibilidades. Por una parte, si las caras septentrionales de exenta y espigón fueron coplanarias, las longitudes cuestionadas serían de $5.50 \mathrm{~m}$. Por el contrario, si la fachada norte de la albarrana enrasaba con la pared sur del pasadizo del postigo, las dimensiones de las caras de levante y poniente se ampliarían hasta $7.50 \mathrm{~m}$. Lo que sí es posible aproximar es la longitud de la cara meridional, $4.50 \mathrm{~m}$, suponiendo medidas similares para el frente septentrional.

La cara meridional del conjunto del baluarte consta de dos tramos. Por una parte, el muro que cierra la construcción por esta zona, y el corto paso albarrano que lo unía con la exenta de los Aljibes. Realmente, el único vestigio de origen almohade por dicho lado es el pequeño espigón, puesto que el actual lienzo sur es una refacción, posterior a la conquista leonesa, forrando el muro primitivo. Éste discurría paralelo al frente meridional del paso albarrano, pero retranqueado $0.70 \mathrm{~m}$ aproximadamente. Esta forma de construcción en cremallera es muy habitual, como sabemos, en las obras militares de los Unitarios. Así pues, la intervención cristiana consistió en forrar el muro primitivo con otro, el hoy visible, cuya cara exterior pasó a ser coplanaria de la cara meridional del espigón, la cual mide 4.10 m de lon-

70 Esta fotografía ha sido publicada en varios libros y catálogos. La edición más antigua de la misma puede verse en N. DÍAZ y PÉREZ, Op. Cit., 1887, p. 675. 
gitud y $11.20 \mathrm{~m}$ de altura desde la base hasta la cima de la merlatura. La cara septentrional, sin embargo, mide tan sólo $2.35 \mathrm{~m}$ de longitud y alcanza $13.80 \mathrm{~m}$ desde el suelo hasta la referida cima de los merlones. De estos elementos prismáticos el paso albarrano conserva dos, uno ya mencionado con forma de $L y$ otro, mutilado en su mitad norte, que corona la primitiva cara que producía el retranqueo del lienzo adyacente al muro cristiano. Éste conserva diez merlones, con sus correspondientes albardillas piramidales, levantados sobre los 14 m de lienzo más próximos al espigón. La altura de este muro se reduce a poco más de $4 \mathrm{~m}$ en el enteste con la muralla de la ciudad. Es en esta zona donde aún pueden verse los restos del pretil y merlón del antemuro empotrados en el lienzo postalmohade, y separados $1.70 \mathrm{~m}$ de la muralla urbana (véase supra). Su altura es de $1.80 \mathrm{~m}$, la equivalente a la de dos hiladas de tapia, una correspondiente al parapeto y otra a la merlatura. El grosor se identifica con el de otros elementos similares conservados, $0.60 \mathrm{~m}$.

Entra en el campo de la hipótesis la existencia de la llamada torre Coracha, que, como su propio nombre indica, se acercaría a la rivera del Marco para proteger el acceso al curso fluvial desde el interior del recinto. Debió de emplazarse a escasos $20 \mathrm{~m}$ de la vaguada y, a pesar de que no se conserva vestigio alguno, es citada por varios investigadores ${ }^{71}$. Incluso, alguno ha especulado acerca de su emplazamiento basándose, suponemos, en la documentación gráfica que hemos consultado. En la fotografía de 1887, referida anteriormente, se observa cómo la cabecera de la ermita de San
Marcos está levantada sobre lo que podría interpretarse como parte del macizo desgastado de la torre. Por otro lado, una acuarela del mismo edificio, dibujada por Gustavo Hurtado en 1896, muestra indicios cuya lectura puede apoyar su existencia ${ }^{72}$.

Por el contrario, no disponemos de ningún dato acerca del trazado del hipotético espigón que la uniría con el baluarte. Basándose en una alineación supuesta con la torre de los Pozos, Fernando Bravo la interpretó conectada a esta última ${ }^{73}$. Sin embargo, el análisis parietal de la del Gitano parece negar el posible enteste de un muro en su frente oriental. Preferimos considerar la posibilidad de que el espigón naciese, en su caso, de la torre de los Aljibes. En ese caso, es muy probable que el adarve del espigón no tuviese acceso al terrado o cámara de la torre con la que entestase ${ }^{74}$.

\section{ANÁLISIS CONSTRUCTIVO}

Desde un punto de vista constructivo, refiramos que, como es común en el recinto cacereño, tanto la torre de los Pozos como su tramo de espigón conservado fueron levantados a base de sucesivas hiladas de tapia de hormigón de cal. Sin embargo, es en esta exenta donde se emplearon modos constructivos diferentes a los utilizados en el resto de albarranas de la fortificación. Así pues, no sorprende que la parte inferior de la del Gitano sea un potente zócalo de mampostería apoyado directamente sobre un macizo rocoso de cuarcita. Pero lo que sí llama la atención son los refuerzos esquineros de idéntico material que el zócalo, y que alcanzan una elevación de $8 \mathrm{~m}$ sobre la base

7I Es citada por G. RODRÍGUEZ CEREZO, Op. Cit., 1988, p. 105; siguiendo a F. BRAVO y BRAVO, Op. Cit., 28 Mayo 1975, p. 9, el cual, además de nombrarla e incluirla en su croquis, supone que sus restos son reutilizados en la construcción de la desaparecida ermita de San Marcos. Por otra parte, María del Mar Lozano Bartolozzi atribuye el nombre de torre Coracha a la de los Aljibes, como denominación secundaria, a la vez que reconoce la posibilidad de la existencia de una coracha a la que no denomina de ninguna manera. Consúltese en M. M. LOZANO BARTOLOZZI, Op. Cit., Cáceres, 1980, p. 70.

72 Según tal dibujo, la cabecera del templo aparece levantada sobre una masa informe que consta de dos partes: la superior, con sus líneas generatrices dispuestas horizontalmente; y la inferior, con sus líneas trazadas oblicuamente. Es posible interpretar éstas como representación de una afloración de cuarcita sobre la que asentaría el macizo de la torre con sus hiladas de relleno de mampuesto o tapia. Su publicación más reciente puede verse en AA. W., Visiones de Cáceres, Cáceres, 1999, p. 38.

73 F. BRAVO Y BRAVO, Op. Cit., 28 Mayo 1975, p. 9.

74 En los restos de uno de los muros de la coracha de la alcazaba de Badajoz se observa tal disposición. Desde luego, creemos que el alejamiento de la torre Coracha respecto al baluarte suponía una gran merma de su capacidad defensiva, la suficiente como para concebirla relativamente aislada del resto del recinto, con miras a evitar un fácil asalto del enemigo a través de esta torre. 
en el frente de levante. Estos refuerzos se observan claramente en las esquinas nordeste, sudeste y se suponen en la suroeste, actualmente sepultada por el huerto. Como las caras septentrionales del paso albarrano y torre son coplanarias no existe ángulo noroccidental susceptible de ser rematado con mampuestos.

Como ya sabemos, sólo las caras norte y este de esta albarrana aparecen totalmente visibles. Resulta curioso el hecho de que, hasta los $8 \mathrm{~m}$ de altura, y coincidiendo con el fin de la fábrica mixta, no se alineen las hiladas de tapia de una y otra cara. Así, mientras que en el frente septentrional, entre el zócalo de mampostería y la cota referida, median cinco filas de cajones, en la cara de levante para el mismo espacio se detectan seis hiladas. Y ello a pesar de la restauración del arquitecto González Valcárcel, en los años sesenta, que no respetó la primitiva ubicación de las cintas de mortero de cal coincidentes con las líneas de mechinales, rehaciendo dicho encintado sin criterio científico. En la referida cota de transición a la fábrica pura de tapia, se rastrean en las caras de levante y meridional sendas hiladas de mampuestos, de unos $30 \mathrm{~cm}$ de altura, que recorren toda la longitud de ambas, a pesar de que en la fachada meridional es más difícil percibirla al estar dicha línea pétrea enrasada con el huerto. Desde esta cota, y hacia arriba, se levantan siete filas de cajones de tapia de las que se conservan todas menos la última, la correspondiente a los merlones, coincidiendo ahora las hiladas de cada cara. De estas siete, las dos primeras corresponden todavía al macizo de la torre, las cuatro siguientes a la cámara con su bóveda y la restante al pretil.

Tanto la albarrana como su espigón están perfectamente trabados $y$, consecuentemente, sus hiladas de cajones alineadas. Es posible que esto se deba a que, por estar el paso albarrano descentrado respecto de la exenta, sus caras septentrionales son coplanarias. Y, lógicamente, en un paramento totalmente liso sin articular, todos los cofres de tapia se disponen trabados. Sin embargo, el lienzo de levante del patio no traba con la de los Pozos, aunque sí lo hace con el pequeño paso albarrano de la de los Aljibes y debió de hacerlo con el primitivo muro meridional del conjunto. Más adelante se darán posibles motivos a esta disposición.

Volviendo al lienzo que ahora nos ocupa, el oriental, comentemos que su parte inferior está constituida por un zócalo de mampostería cuarcítica que, en el entorno del postigo, zona meridional, alcanza una altura de $6 \mathrm{~m}$ sobre el suelo. Esta magnitud se ve reducida en su tramo norte a escaso I m, al cimentar directamente encima del macizo rocoso. Las dovelas del arco del postigo son de grandes mampuestos graníticos bastante irregulares. El paramento situado entre la jamba septentrional del vano y la afloración rocosa está dispuesto en ligera escarpa. Por encima del basamento se elevan un total de diez hiladas de tapias, que se convierten en ocho en el extremo norte y once en el meridional, a causa de que la separación entre la zona de mampostería y la parte de tapia experimenta quiebros en los mencionados extremos. Como es habitual, las dos filas cimeras coinciden con pretil y merlatura.

Lo que subsiste de la torre de los Aljibes, así como de su pequeño espigón, está construido de idéntica manera. Tal paso albarrano contaba con once hiladas en todas sus caras, excepto en la mitad occidental del frente sur, donde se elevan ocho filas de cajones debido al comentado escalonamiento que sufre la base de mampostería.

El muro meridional primitivo del baluarte también debió contar con un zócalo de mampostería, que iría elevándose a la par que el terreno donde cimenta, sobre el que se alzarían las sucesivas hiladas de tapia. Sin una intervención arqueológica resulta imposible comprobar el estado actual del lienzo, pues su cara interna está enterrada en el huerto y la externa adosada al lienzo postalmohade. Éste fue construido en su totalidad con fábrica de mampuestos; se puede observar una línea de ellos, más menudos, que recorre la base del parapeto.

\section{HIPÓTESIS FUNCIONALES}

Ciertos factores invitan a pensar que el conjunto de la torre de los Pozos pudiera ser producto de dos fases constructivas sucesivas, den- 
tro de la gran reforma almohade. Así, en un principio, quizás se levantara la propia torre del Gitano con su correspondiente espigón. En un momento posterior indeterminado, pero anterior a la conquista leonesa, se erigirían los lienzos meridional y oriental que, junto a lo ya construido, generaron el baluarte actual. También pertenecerían a esa última fase la torre de los Aljibes, con su espigón, y el postigo de acceso. El espacio englobado quedaría constituido como un patio. Esta especulación acerca de dos etapas edilicias puede verse reafirmada por la equidistancia de un cubo de la muralla (referido como G) a las albarranas de los Pozos y de la calle Hernando Pizarro. Si el conjunto del baluarte hubiese sido edificado de una vez, habría resultado más lógico situar el mencionado cubo a la misma distancia de la exenta de Hernando Pizarro que del lienzo meridional del conjunto. Además, téngase en cuenta que la torre de los Pozos y el lienzo oriental adyacente no traban entre sí, lo cual puede corroborar la diferencia cronológica propuesta para ambas construcciones. No obstante, esta cuestión también puede reflejar un simple criterio constructivo de establecer una línea de junta constructiva, muy común en obras hormigonadas masivas. Es decir, aunque la teoría sea atractiva, no deja de ser una hipótesis de trabajo de difícil comprobación sin ninguna excavación arqueológica que venga a corroborar o desmentir la misma.

La nueva ampliación respondería a una doble demanda funcional. Por una parte, incrementar la capacidad defensiva de la vecina alcazaba al anteponer nuevos elementos poliorcéticos. Por otra, acortar distancias entre el recinto amurallado y el único curso de agua cercano. Insistiendo en la función que poseería este importante conjunto, caben aportar varias reflexiones que, tal vez, vengan a arrojar algo de luz sobre el tema. Lo primero que llama la atención de esta construcción es su sensible proyección hacia el exterior del recinto. Pensamos que esta cuestión es fundamental para el análisis del baluarte. Si estudiamos su situación, comprobamos cómo aprovecha un importante afloramiento rocoso que, aparte de constituir un serio padrastro para la integridad de la cerca inmediata, servía para dominar el punto de mayor proximidad con el arroyo de la rivera del Marco. Seguramente, el objetivo perseguido con la construcción de esta defensa adelantada era dominar este punto estratégico de aguada desde la alcazaba, evitando cualquier aproximación enemiga y permitiendo un acceso protegido a la guarnición local. A tal fin responderían la presencia de la supuesta torre coracha y el citado postigo. Además, recuérdese la toponimia que presentan todas las estructuras que forman parte de este baluarte, relacionada con elementos hidráulicos: pozos, aljibes y coracha.

\section{DECORACIÓN Y EPIGRAFÍA ALMOHADES EN LA TORRE DE LOS POZOS}

En el revestimiento original de la torre de los Pozos se concentran los únicos vestigios epigráficos y de exorno originales que se conservan en toda la fortificación cacereña. De hecho, se han podido localizar en esta albarrana dos estrellas de ocho puntas, un resto de inscripción cúfica y una cinta anudada, inéditos los dos últimos hallazgos (Lám. 9).

Las mencionadas estrellas se localizan en el frente oriental de la exenta, sobre la primera hilada sin mampostería de las esquinas. Cada una de ellas está situada a I m aproximadamente de los extremos de la fachada. No son elementos aislados, sino que forman parte de una decoración de sillares fingidos y formas curvas que asemejan lágrimas. La estrella próxima a la esquina septentrional está constituida por dos cuadrados, de aproximadamente $0.35 \mathrm{~m}$ de lado, superpuestos, y girado uno de ellos $45^{\circ}$ respecto del otro. En la génesis del diseño se eliminan las líneas interiores de la estrella, trazándose únicamente las del contorno. Mientras que las esquinas del cuadrado apoyado en su base no tocan ningún elemento, los vértices del otro prolongan sus lados en los ángulos superior e inferior y conectan con líneas curvas. El izquierdo queda tangente a una vertical y el derecho se une a unos trazos curvos en forma de lágrimas que, próximas a la esquina, enlazan con otras líneas horizontales y verticales que simulan sillares. La otra estrella es escasamente mayor que la anterior, pues los lados de los cuadrados que la gene- 
ran miden aproximadamente $0.40 \mathrm{~m}$. Ésta y su decoración adyacente se organizan exactamente igual que la descrita pero, lógicamente de forma simétrica. Todas las líneas que dibujan los motivos ornamentales están realizadas mediante cintas de mortero de cal, muy fino y casi bruñido, de $5 \mathrm{~cm}$ de ancho.

Cáceres no es el único lugar donde se encuentran aplicados tales motivos en la fachada principal de una torre. Sobre el enlucido de una de las del Castillejo de Monteagudo, en Murcia, se hallan incisas una pareja de estrellas similares a las que nos ocupan. Según Julio Navarro Palazón y Pedro Jiménez Castillo, en el caso murciano, estas formas cumplirían una función profiláctica, protegiendo de la fascinación al edificio en cuestión ${ }^{75}$. Sin embargo, el resto de los elementos identificados en nuestro caso abogan por un conjunto representativo de carácter propagandístico.

En cualquier caso, el principal hallazgo aquí presentado lo constituye la inscripción localizada en el frente septentrional de la torre (Fig. 12). Se ubica en la mitad superior de la cuarta hilada de cajones de tapia, lindando con la mampostería de la esquina y a dos metros de ésta. Está inscrita dentro de una cartela de 40 $\mathrm{cm}$ de alto por $50 \mathrm{~cm}$ de ancho aproximadamente. Consta de tres trazos situados a la misma altura y un cuarto ligeramente más elevado que monta sobre el límite izquierdo de la cartela. Tanto los caracteres cúficos, como las formas decorativas situadas debajo de aqueIla, están ejecutadas al igual que las estrellas, con cintas de mortero de cal.

Para establecer el significado de este testimonio epigráfico y, puesto que no somos arabistas, hemos contado con el consejo de la Dra. María Antonia Martínez Núñez. Según su criterio, el primer término formado por tres trazos podría ser interpretado como Allah ("Dios"), al que le faltaría un grafema inicial (lam), o tam- bién como inna-hu ("Ciertamente Él'). En cuanto al trazo aislado ubicado en un nivel ligeramente superior podría corresponder al comienzo de la expresión rabbu-na ("nuestro Señor"), lo que implicaría que se ha perdido la última parte de esa expresión. Así, la lectura y traducción podría ser: Allah ra[bbu-na] ("Dios es nuestro Señor") o inna-hu ra[bbu-na] ("Ciertamente Él es nuestro Señor"). La primera posibilidad, a pesar de la falta de un grafema, es la más aceptable, pues está ampliamente documentada en el mundo almohade como vemos en sus típicas acuñaciones en plata. En cualquier caso, las dos versiones vienen a expresar un mismo concepto afín.

El paralelo más próximo se conserva, descontextualizado, en el museo de Jerez de la Frontera ${ }^{76}$. Se trata de un friso de piedra del que se conservan dos fragmentos. Uno contiene una cartela epigráfica en cúfico tallado en un relieve muy semejante al caso que nos ocupa y con el mismo contenido: Allah rabbuna ("Dios es nuestro Señor"). Aunque fue hallado fuera de su ubicación original, parece que el friso procede de una de las puertas de la ciudad. El otro muestra una estrella de ocho puntas muy austera. Así, estos son los restos más próximos que pueden identificarse, a día de hoy, con los elementos parietales de la torre de los Pozos. En opinión de la Dra. Martínez Núñez, tanto en el caso de Jerez como en el extremeño, los textos están incompletos, pues deberían incluir breves elogios a Dios o completarse con las leyendas que en los dirhemes de plata almohades siguen a la expresión conservada: Muhammad rasulu-na ("Mahoma es nuestro enviado"), al-Madhi imamu-na ("El Mahdi es nuestro guía"). En el caso de Cáceres es posible que la expresión conservada, aunque incompleta, tuviese su conclusión en la cara oriental de la albarrana y que, a la misma cota y a lo ancho de ese frente, se ubicasen las otras posibles leyendas en cartelas semejantes a la conocida. Por desgracia, la zona

75 Para consultar de manera más extensa la opinión de estos investigadores, véase J. NAVARRO PALAZÓN y P. JIMÉNEZ CASTILLO, "El castillejo de Monteagudo: Qasr Ibn Sad", Casas y palacios de Al-Andalus, Barcelona, 1995, pp. 94 y 95.

76 B. PAVÓN MALDONADO, Jerez de la Frontera. Arte islámico y mudéjar. Madrid, 198I, pp. 8 y 9 , Fig. 
del paramento donde pudieron situarse se encontraba muy erosionado antes de la intervención del arquitecto José Manuel González Valcárcel, por lo que fueron parcheadas todas las tapias.

Resulta cuanto menos llamativo comprobar cómo, en ambas fortificaciones, no sólo ha subsistido idéntica manifestación, sino también similares motivos ornamentales, las estrellas de ocho puntas. Las inscripciones localizadas en ambas ciudades constituyen dos interesantes ejemplos de epigrafía estatal muminí en obras militares andalusíes que viene a referir la ideología que subyace en el nuevo régimen. Rompiendo con lo habitual hasta entonces, estos testimonios de carácter oficial reproducen textos exclusivamente de contenido religioso: citas coránicas, frases de alabanza al Dios único y alusiones a Muhammad y su misión profética, prescindiendo de formularios fundacionales. Así, se otorgará a la epigrafía, junto a otros elementos decorativos, una monumentalidad en los revestimientos exteriores de los edificios de la que se había carecido hasta entonces. Esta forma de entender los tratamientos parietales perdurará en siglos posteriores, como ocurre, por ejemplo, en alguna torre de la fortificación de Gibralfaro, tal vez de origen meriní ${ }^{77}$.

La propaganda almohade no se plasma de idéntica manera en Al-Andalus y el Magreb. Mientras que en tierras peninsulares se manifiesta fundamentalmente a través de fundaciones religiosas, en África aparece tanto en este tipo de obras como en otras militares. El ejemplo más evidente lo tenemos en las puertas monumentales edificadas en Marrakech y en Rabat, innovadoras y sin parangón alguno en al-Andalus, con sus frisos epigráficos y su ornamento de lazo y ataurique ${ }^{78}$. En este contexto, Cáceres y Jerez constituirían una excepción, aunque modesta, a la norma ${ }^{79}$. ¿Cuál sería entonces la justificación de este hecho en el enclave extremeño? Es posible que la situación de fortaleza de vanguardia frente al enemigo cristiano explique el afán de propaganda de una dinastía que tenía en la guerra santa una de sus señas de identidad. En estas condiciones es posible suponer que el programa propagandístico de los Unitarios hubiese tenido dos destinatarios: por un lado los leoneses, como componentes de un ente social, político y militar ajeno al mundo musulmán. Por otra parte, habría que comprobar hasta qué punto la población autóctona, aunque islámica, percibiría a los muminíes como elementos extraños que serían tolerados en la medida de su eficacia militar frente a los primeros. La aparición de dichas formas en esta fortaleza fronteriza, evidentemente propagandísticas, serviría para manifestar la presencia de un promotor poderoso, con el sello del Estado almohade. Un movimiento dotado de una fuerte carga dogmática que se plasmaba a través de un amplio y característico programa de manifestaciones ideológicas y de poder. Por otro lado, a la escasa población autóctona, tal despliegue de medios poliorcéticos debía proporcionar no sólo seguridad física sino, y gracias a la legitimidad que expresaba su propaganda, seguridad psicológica; sentirse protegidos por las armas de una dinastía aparentemente poderosa.

Volviendo a la torre de los Pozos, en la primera hilada y la mitad inferior de la segunda del frente norte, y recorriendo el límite entre la obra encofrada y la mampostería, aparecen dos cintas que a media altura de la primera se entrelazan formando un nudo. Las líneas que definen los motivos fueron incisas cundo el mortero se hallaba todavía fresco. Parece ser que al ejecutarse, se obvió el trazado del segmento central del nudo, que, completado, sería similar a otros repetidos continuamente en elementos ornamentales almohades.

\footnotetext{
77 M. ACIÉN ALMANSA y M. A. MARTíNEZ NÚÑEZ, "Datos arqueológicos de la presencia meriní en Málaga", Fez et al-Andalus, Fez, 1995 (inédito).

78 En relación con el carácter propagandista de estas puertas consúltese, M. A. MARTíNEZ NÚÑEZ, "Epigrafía y propaganda almohades", Al-Qantara, XVIII, 2, Madrid, 1997, pp. 4I5 a 445.

79 Con un sentido similar cabría referir el friso epigráfico en piedra conservado en Loja, de eminente carácter religioso, y que se atribuiría a periodo almohade; véase, ibidem, 1997, p. 427, Lám. I, Fig. 2.
} 
No es posible saber, a día de hoy, si otras torres de la cerca cacereña ostentaban algún tipo de ornato. En cualquier caso, pensamos que no es casual que los únicos testimonios propagandistas y de legitimidad se encuentren concentrados en una misma construcción. Si se parte del supuesto de que la torre de los Pozos recibió un tratamiento superficial diferente al de las demás exentas del recinto, tal condición debiera relacionarse con una especial significación de la misma. Así, esta circunstancia vendría a reforzar nuestra hipótesis de que este baluarte formaba parte, no de la muralla urbana propiamente dicha, sino de la alcazaba, erigiéndose más que a modo de prolongación, como parte integrante de la misma.

\section{ASPECTOS CONSTRUCTIVOS: DEFINICIÓN DE ESTRUCTURAS Y FÁBRICAS}

En primer lugar, debemos comentar que, aunque la mayor parte de la obra conservada pertenece al impulso edilicio almohade, en ésta se aprovechan materiales y elementos defensivos de origen romano (Fig. 4), como ocurre en el Arco del Cristo, así como de una fortificación islámica anterior ${ }^{80}$. Puede comprobarse con certeza cómo en el caso de las torres de Yerba, Horno y Aver, sus espigones arrancan desde cubos más antiguos construidos con mampostería trabada con mortero de cal y reforzada con sillares formando encadenados en las esquinas. Concretamente, en las del Horno y del Aver, se observa cómo el cubo primitivo fue cerce- nado en su parte superior para apoyar el arco correspondiente del paso albarrano, que tendrá la misma anchura que el elemento que prolonga. Intervenciones coetáneas, y de similar carácter, se observan con claridad en la fase muminí de la cerca de Écija, en concreto en las exentas de las calles Calzada y Barrera de Quintana ${ }^{81}$. Otras actuaciones de parecido concepto poliorcético, pueden verse en las albarranas de la alcazaba emeritense, posiblemente almohades ${ }^{82}$, así como en el recinto defensivo de Talavera de la Reina, ya de autoría cristiana 83. Sin embargo, aún restan otros vestigios importantes que nos permiten conocer cómo eran las obras defensivas islámicas anteriores a la intervención almohade. Un ejemplo significativo lo tenemos en el sector de la puerta de Coria, entre las torres del Rey y del Socorro, donde queda al descubierto la cara externa de la parte inferior de un lienzo de muralla construido a soga y tizón, con sillares y ménsulas romanas de granito reaprovechados. Diversas cronologías hay propuestas para tal fragmento, desde autores que defienden una filiación tardorromana ${ }^{84}$, hasta otros que proponen un ascendente omeya ${ }^{85}$. Dada la falta de excavaciones arqueológicas, y puesto que casi todo el perímetro de la cerca no es visible dado el adosado de construcciones a ambos lados, no es posible conocer si existen otros restos constructivos de similares características.

Volviendo al recinto que nos ocupa, casi todos los lienzos están construidos en su parte inferior con mampostería trabada con mortero de cal. Hasta que no se realicen estudios

80 Tradicionalmente, se ha considerado como romana la fase previa a la intervención almohade. Sin embargo, Fernando Valdés ha sido el primero en considerar una etapa constructiva islámica anterior a la muminí, aun reconociendo una primera obra romana. Consúltese F. VALDÉS FERNÁNDEZ, Op. Cit., I99I, p. 550.

8I Observaciones realizadas en ciertos tramos de la cerca astigitana apuntan en este sentido. En cualquier caso, este recinto y sus ampliaciones fueron estudiados con detenimiento por J. HERNÁNDEZ DÍAZ et alii, Op. Cit., 1943-1951, pp. 21 I a 227.

82 Atribuye una cronología almohade a tres de las albarranas de la alcazaba de Mérida, al igual que a las de Trujillo, F. VALDÉS FERNÁNDEZ, Op. Cit., 1991, p. 554.

83 Véase, por ejemplo, el caso de una de las torres albarranas de Talabira, donde la intervención cristiana se superpone a un cubo islámico anterior. S. MARTíNEZ LILLO, Arquitectura militar andalusí en la Marca Media. El caso de Talabira, Talavera, 1998, pp. 108 a 138.

84 Opinión recogida en conversación mantenida con el profesor Enrique Cerrillo Martín de Cáceres.

85 Según Fernando Valdés, el recinto prealmohade, fechado en época omeya, estaría constituido por sillares graníticos dispuestos a soga y tizón. F. VALDÉS FERNÁNDEZ, Op. Cit., 1999, p. 239. 
parietales concienzudos, no se descarta que parte de tal obra pudiera pertenecer a un momento constructivo prealmohade ${ }^{86}$. En cualquier caso, la fase Unitaria también constaría de labores de mampostería en la parte inferior de las cortinas, al menos para crear un zócalo sobre el cual apoyar la primera fila de cajones de tapia, y elevada por encima de la mitad de la altura total del muro en muchos casos. Así, la técnica constructiva almohade por antonomasia, el tapial, será la que se aplique de forma generalizada para configurar la mayor parte del alzado de los muros sobre el basamento pétreo. Para ello se empleará un hormigón calizo (tabiya) muy fino y resistente, con una granulometría muy cuidada que incluye gravas y cantos en proporciones variables, pero nunca excesivas. En ocasiones se han localizado incluso restos óseos y escorias férricas.

Observando la planta del recinto, se puede percibir con claridad el clásico trazado en cremallera de los lienzos, lo cual está relacionado directamente con la técnica edilicia aplicada, en la que se recurre a grandes elementos lineales y monolíticos como son los encofrados o tapiales, tan poco adecuados a su empleo en terrenos sinuosos ${ }^{87}$.

En cuanto a las torres exentas, en todas ellas se resuelven sus muros y estructuras con tapia de hormigón calizo, constituyéndose su basamento, por regla general, con sillares romanos reutilizados y aparejados a menudo a soga y tizón, o con un zócalo de mampostería. Todas estas construcciones son macizas hasta la cota del adarve del paso albarrano, situándose a ese nivel una cámara abovedada y sobre ésta la terraza con parapeto y merlatura. La parte de tapia del macizo abarca entre siete y once hila- das de cajones dependiendo de las dimensiones de la torre. Cuatro será, sin embargo, el número invariable de esas hiladas comprendido entre el suelo de la estancia y la superficie de la terraza que está por encima. Las dos últimas filas de los encofrados se corresponden con el pretil y la merlatura. La superficie de parapeto comprendida entre merlones cuenta, de forma sistemática, con dos rebajes curvos observados en un amplio conjunto de obras militares almohades: Sevilla, Écija, Badajoz, Alcácer do Sal, Reina, Carmona, Hornachos o Elvas ${ }^{88}$. Hemos de referir, no obstante, que esta singular forma no parece exclusiva del mundo almohade, ya que se identifica en periodo taifa en las construcciones de tapia que constituyen la muralla de la Hoya (jandaq bab Musa) de Almería ${ }^{89}$. Las causas de esta singular forma bien pudiera estar relacionada con el empleo de encofrados para la construcción de los merlones hormigonados; para ello, sería preciso practicar una pequeña entalladura sobre la tapia del pretil inferior.

Por todos es conocida la costumbre de los constructores de este periodo de marcar, en cubos y torres, el inicio de parapetos y merlones con sendas impostas de ladrillo, como vemos en los recintos de Badajoz, Sevilla, Écija, Carmona o Jerez de la Frontera. Incluso en el caso de poseer cámara, su suelo también se señala exteriormente con otra verdugada similar. Sin embargo, llama la atención la total ausencia de estos elementos en el caso cacereño, dando una apariencia más austera a todo el conjunto. Por una parte, sería posible atribuir esta característica a la gran celeridad con la que se debió edificar el recinto, prescindiendo de toda manifestación de exorno. En otros lugares fortificados también puede comprobarse la falta de dichas verdugadas, como es el caso de Alcá-

86 Fernando Valdés refiere algunas de las torres de la fase islámica como anteriores a la obra edilicia almohade, en las que identifica materiales y modos constructivos concretos. Sin embargo, no especifica la composición de los lienzos en esa etapa. F. VALDÉS FERNÁNDEZ, Op. Cit., 1998, pp. 173 a 176 y 183.

87 P. GURRIARÁN DAZA y A. J. SÁEZ RODRÍGUEZ, Op. Cit., (en prensa).

88 Se identifica esta particular forma constructiva en las almenas conservadas en la Casa de la Cultura de Elvas; consúltese, F. B. CORREIA, Op. Cit., 2002, p. 36I, Fig. II.

89 Estas estructuras serían promovidas por el eslavo Jayran al-Amirí (403H/I0I2-419H/I028) quien, según refiere al-Himyari en su Rawd al-Mi'tar, rodea de una muralla de tierra el barrio conocido como al-Musalla, en respuesta al rápido crecimiento de la ciudad. Véase, AL-HIMYARI, Kitab ar-Rawd al-Mi'tar, Trad. M. P. Maestro González, Valencia, 1963, p. 367. 
cer do Sal, otra fortaleza de vanguardia. Por otro lado, la razón de esa ausencia pudo deberse a localismos y a usos constructivos propios de las cuadrillas que acometieron la edificación, por lo que es difícil establecer normas al respecto.

Es habitual en estas obras militares encontrar albardillas piramidales coronando merlaturas, tal y como puede comprobarse en casos como Sevilla, Jerez de la Frontera, Niebla, Carmona o Badajoz, por citar algunos ejemplos. En Cáceres, a pesar de conservarse una cantidad relativamente elevada de merlones, actualmente no quedan vestigios fiables de tales remates piramidales a los que se les pueda atribuir una cronología almohade. Aun así, es posible que, primitivamente, se dispusiesen esos elementos. En efecto, existe documentación fotográfica donde aparecen rematando dos merlones del lienzo comprendido entre las torres del Horno y de la Yerba ${ }^{90}$. Por otra parte, hasta hace aproximadamente una década, otro par de prismas albardillados subsistían aún en el tramo de muralla inmediato a Torremochada, hacia poniente. Tras su parcial desmoronamiento fueron rehechos, perdiéndose la posibilidad de poder practicar en ellos análisis que permitan identificar posibles pistas acerca de su origen. En cualquier caso, refacciones ejecutadas durante los siglos XIV y XV en las torres de Bujaco y del Río aún ostentan tales piramidones. Esta circunstancia nos puede inducir a suponer que tales elementos, ejecutados con posterioridad a la definitiva conquista leonesa, debieron de disponerse miméticos a los construidos anteriormente para así conservar la unidad del conjunto.

\section{MORFOLOGÍA DE LOS ENCOFRADOS}

Las alturas de los cajones de tapial no son idénticas para todo el recinto; así, abundan las que oscilan entre 0.80 y $0.90 \mathrm{~m}$ con predominio de las segundas, aunque también hay paramentos con hiladas cuyas cotas abarcan entre 0.65 y $0.70 \mathrm{~m}$. De manera excepcional, podemos observar una hilada, en la cara septentrional de la torre de los Pozos, de más de un metro de altura. Como nuestra experiencia en el estudio de obras militares de tapia nos ha señalado, aunque estas dimensiones rondan una magnitud en torno a $0.80 \mathrm{~m}$ (dos codos ma'muni), no es posible encontrar cánones al respecto 9!. Así, las dispersiones habituales responderán a localismos y otros factores coyunturales. En las superficies de los paramentos mejor conservados pueden apreciarse todavía las huellas de los tablones de madera, contándose entre cuatro y cinco el número de éstos que constituían cada cara del encofrado ${ }^{92}$.

Se ha podido comprobar sistemáticamente cómo los mechinales estaban ocupados por agujas de madera que no atravesaban todo el grosor del cajón, de forma que se resolvían mediante dos independientes dispuestas en cada extremo. Penetraban entre 0.65 y $0.85 \mathrm{~m}$ e iban aseguradas al interior mediante unas cuñas de madera que, a modo de clavos, las fijaban sobre la argamasa de la hilada inferior. Similar método constructivo se constata con claridad en obras muminíes como Reina, Alcácer do Sal - El Vacar, aunque esta última construcción se tenga habitualmente por obra califal ${ }^{93}$. Es presumible que se erigiesen de la misma manera todas las obras militares en las cuales el grosor

90 La destrucción de este lienzo ya se refirió en su apartado correspondiente (véase supra). En cualquier caso, véase la documentación fotográfica recogida en J. R. MARCHENA PÉREZ, Op. Cit., 1984, pp. 25 y 26.

9I Véase, P. GURRIARÁN DAZA y A. J. SÁEZ RODRÍGUEZ, Op. Cit., (en prensa).

92 Como norma general, cada tabla suele tener unos doce o quince centímetros de altura y no más de cinco centímetros de espesor. Ibidem, (en prensa).

93 De forma tradicional, se ha venido refiriendo esta fortificación como realizada en periodo califal, véase, por ejemplo, L. TORRES BALBÁS, "Arte hispanomusulmán hasta la caída del califato de Córdoba", España Musulmana hasta la caída del califato de Córdoba (7/ I-1031). Historia de España dirigida por Ramón Menéndez Pidal, tomo V, Madrid, 1957, pp. 646 y 647. Sin embargo, creemos que sus aspectos constructivos parecen delatar una más que probable promoción almohade de la obra. Similar revisión cronológica encontramos reflejada en J. L. MENÉNDEZ FUEYO et alii, "El falso despiece de sillería en las fortificaciones de tapial de época almohade en al-Andalus", Actas del I congreso de Castellología ibérica, Palencia, 1988, p. 493. 
de los muros superase los dos metros ${ }^{94}$, en cuyo caso no era práctico el empleo de una aguja continua. Téngase en cuenta que los lienzos de la obra almohade de Cáceres poseen una latitud de $2.60 \mathrm{~m}$ aproximadamente.

\section{TRATAMIENTOS EPIDÉRMICOS. REVESTIMIENTOS}

Los restos de revestimientos originales conservados en esta fortificación son muy fragmentarios y escasos. Aun así, es posible hacerse una idea del aspecto exterior de torres y lienzos en época almohade. Parece ser que la labor de tapia iba recubierta por un fino revoco rojizo, visible aún con bastante claridad en la cara septentrional de la albarrana de los Pozos. También contarían con un tratamiento epidérmico similar los zócalos pétreos de las torres, como se aprecia en la torre del Aver. Además, sobre el revoco se desarrollaban unas cintas de enlucido de mortero de cal, casi bruñido, enmarcando las juntas de cada cajón de argamasa, e incluso cada mampuesto como puede verse en el caso de la torre de los Pozos. Estas cintas tienen un grosor variable entre ocho y cuatro centímetros ${ }^{95}$, y un relieve entre uno y dos centímetros. Un caso singular lo representan un conjunto de cintas dispuestas de forma oblicua en los paramentos del lienzo de levante del baluarte de la torre de los Pozos. Resulta evidente que este trazado responde a la necesidad de cubrir las juntas así dispuestas entre cajones adyacentes. Como ya se ha comentado en alguna otra investigación, tal solución se debe a interrup- ciones en las labores de construcción de tapias inmediatas que no requieren el uso de encofrados cabeceros ${ }^{96}$.

El estudio de los revestimientos de estas estructuras nos ha permitido constatar cómo todos los pretiles y merlones del recinto estuvieron enlucidos completamente con una gruesa capa blanquecina de mortero de cal, cuya función, aparte de la estética, debió ser la de convertir en hidrófugas aquellas partes en las que la exposición a la lluvia y la acumulación de agua era mucho mayor, evitando así humedades peligrosas en las fábricas. Vestigios de esta solución son apreciables en las torres de los Pozos, Horno, Postigo de Santa Ana, Aver y Redonda. Además, se identifica en el cubo y tramos de muro conservados entre las albarranas del Postigo de Santa Ana y Redonda. Esta singular forma de proteger las tapias cimeras de la construcción no es una técnica exclusiva de Cáceres, pues la hemos podido identificar en otras obras defensivas almohades. En efecto, las tapias que forman las estructuras militares mandadas construir por el califa 'Abd alMu'min en el año II60 en Gibraltar ${ }^{97}$, y que aún se conservan en amplios tramos, presentan idéntica solución epidérmica. Similar circunstancia la hemos apreciado en un lienzo cercano a la puerta del Socorro del recinto urbano de Niebla, de más que probable datación almohade ${ }^{98}$. Estas sorprendentes similitudes, hasta ahora no referidas en ninguna investigación, nos permiten aventurar, dada la diferencia cronológica y geográfica entre estos ejemplos, que no se trataba de una solución

94 Para conocer la puesta en obra de las construcciones de tapia militar, consúltese F. J. LÓPEZ MARTíNEZ, , "Tapias y tapiales", Loggia, Nº 8, 1999, pp. 74 a 88, así como, P. GURRIARÁN DAZA y A. J. SÁEZ RODRÍGUEZ, Op. Cit., (en prensa).

95 Tal fajeado puede observarse todavía en torres y muros de Badajoz, Alcácer do Sal, Paderne, Salir, Silves y Moura, por citar algunos ejemplos cercanos temporal y geográficamente. Para conocer una lista sistematizada de las obras militares que lucen encintados, léase J. L. MENÉNDEZ FUEYO et alii, Op. Cit., 1988, pp. 48I a 5II. Pensamos que, con independencia de labores de engaño relacionadas con la simulación de grandes aparejos de sillería, este tratamiento parietal estaría más relacionado con la protección e impermeabilización de las juntas constructivas entre cajones de tapia, P. GURRIARÁN DAZA y A. J. SÁEZ RODRÍGUEZ, Op. Cit., (en prensa).

96 Ejemplos similares a este de Cáceres los tenemos en los recintos defensivos de Jerez, Niebla, Reina y Almonaster; véase, ibidem, (en prensa)

97 Véase el completo relato que realiza IBN SAHIB AL-SALA, Al-Mann bil-Imama, Trad. A. Huici Miranda, Valencia, I969, pp. 21 y ss.

98 Eso parece deducirse de las últimas investigaciones sistemáticas realizadas sobre este recinto defensivo; véase, por ejemplo, J. A. PÉREZ MACÍAS et alii, "Las murallas de Madina Labla (Niebla, Huelva)", Actas I Congreso Internacional Fortificaciones en al-Andalus (Algeciras, noviembre-diciembre, 1996), Algeciras, 1998, p. 35I, así como "Niebla, de oppidum a madina", Anales de Arqueología Cordobesa, 11, Córdoba, 2000, p. 117. 
puntual y localista, si no que, posiblemente, era de común recurso por los alarifes almohades en construcciones militares.

En cuanto a revestimientos más elaborados, por ejemplo, para tratamientos de exorno, subsisten interesantísimos restos en la exenta de los Pozos, resolviendo inscripciones y figuras geométricas que fueron tratadas en su apartado correspondiente (véase supra).

\section{SOBRE LA CRONOLOGÍA Y FUNCIÓN DEL RECINTO ALMOHADE}

Tal y como se comentó en su momento, a la hora de estudiar una posible cronología para la última fase constructiva del recinto cacereño, hemos de asumir una serie de carencias documentales y arqueológicas que se nos antojan fundamentales para establecer una correcta secuencia de ocupación diacrónica del lugar. De este modo, al abordar la cuestión hemos de plantear de qué elementos de análisis disponemos y cómo deben utilizarse de forma coherente.

Desde las opiniones vertidas por Torres Balbás, todos los autores están de acuerdo en encuadrar esta amplia reforma dentro del importante impulso edilicio promovido por los tres primeros califas almohades en al-Andalus, y, más concretamente, bajo la égida de Abu Ya'cub Yusuf. A falta de otros mimbres, que simplemente no existen en la actualidad, la coyuntura política de la zona en la segunda mitad del siglo XII y la identificación constructiva y formal con un tipo de fortificación muy concisa que se suele atribuir al mundo Unitario, han servido como justificación para adoptar un punto de vista correcto pero que, a veces, peca de poco riguroso. Sirva de ejemplo la reflexión de Torres Balbás sobre la cronología de las murallas de Cáceres, donde se atribuyen con acier- to al período almohade, pero que no deja de resultar vaga cuando intenta precisar una fecha más concreta para la que recurre a una supuesta similitud con la alcazaba pacense y su cercanía geográfica ${ }^{99}$. En efecto, las murallas de Cáceres pueden tener tanto parecido con ésta como, por ejemplo, con Sevilla, Niebla o Écija, de modo que pensemos que intentar establecer el origen de aquellas siguiendo tal proceder es ciertamente arriesgado.

En cualquier caso, el simple estudio morfológico-constructivo de la fortificación que nos ocupa nos revela de forma certera una paternidad muminí de la misma. Para ello, nos basamos en ciertos elementos que, sin ser concluyentes ni definitorios, sí son eventuales fósiles directores o arquetipos dada su proliferación en determinados períodos. Al referirnos a las obras defensivas almohades, estos suelen ser, sobre todo, torres albarranas, octogonales, antemuros y puertas acodadas, y detalles como el empleo de impostas en torres, encintados de cal o rebajes en parapetos. A ello habría que añadir el uso sistemático de la técnica del tapial para resolver dichas estructuras. Aunque en la actualidad se pone en duda la génesis de tales tipos, retrasándose en la mayoría de los casos su aparición a período omeya ${ }^{100}$, la conjunción de los mismos en una construcción, y su carácter bien evolucionado, pueden resultar definitorios para aclarar su cronología; tal es el caso de Cáceres.

Sin embargo, conviene matizar un interesante aspecto derivado del estudio concienzudo de las fortificaciones almohades, que no es otro que la heterogeneidad que subyace dentro de esa depurada concepción poliorcética que se establece en dicho momento en al-Andalus. Así, aunque los arquetipos antes comentados son una constante en estas construcciones, su empleo y combinación será muy diversa, de

99 Comenta este arquitecto: "[...] Es razonable suponerlas contemporáneas de las de Badajoz, por su semejanza, y debidas a la iniciativa del monarca Abu Ya'cub Yusuf (558=| $63-580=\mid$ | 84) [...]"; L. TORRES BALBÁS, Op. Cit., 1948, p. 466. A partir de esta opinión pionera, prácticamente todas las investigaciones posteriores adoptan sin reservas idéntica hipótesis.

100 En Calatrava la Vieja, por ejemplo, se identifican torres albarranas y puertas en recodo como construidas en el siglo IX; véase, M. RETUERCE VELASCO y M. A. HERVÁS HERRERA, "Calatrava la Vieja. De medina a encomienda", Mil anos de fortificaçoes na Península Ibérica e no Magreb (500-1 500), Lisboa, 2002, p. 313. 
modo que cada recinto reflejará un espíritu propio, fruto de condicionantes particulares y locales. Es por ello por lo que, a pesar de que se pueden registrar ciertos vínculos geográfi$\cos ^{101}$, la realidad conocida sugiere una riqueza formal inusitada. Incluso podemos extrapolar esta variedad al caso de un mismo recinto, como ocurre con la fortificación cacereña. En efecto, el estudio de esta obra revela un mismo impulso constructivo que no excluye la existencia de sensibles diferencias entre los distintos elementos de flanqueo. Podemos señalar a este respecto, por ejemplo, la forma de resolver las estancias de las albarranas, donde encontramos todo un repertorio de plantas y bóvedas, que en algún caso se repiten. También merece la pena referir ciertas diferencias formales, apreciadas en la merlatura, y otras constructivas, como sucede en la concepción de los basamentos de torres y muros.

Quizás sea más útil a la hora de realizar un estudio comparativo entre la fortificación cacereña y el resto de la producción militar contemporánea, fijarnos, más que en la propia globalidad del recinto, en los diversos elementos formales y edilicios que lo constituyen, sin ser éstos concluyentes cronológicamente. La cuestión resulta evidente cuando comprobamos cómo la propia organización general de la muralla de Cáceres no tiene par en el resto del territorio andalusí dada la proliferación de albarranas. No podemos afirmar lo mismo acerca de los diferentes arquetipos citados, donde sí se pueden identificar paralelos puntuales con diversas construcciones defensivas. Ocurre, por ejemplo, con la similitud formal entre las torres del Aver y del Postigo con la albarrana del albacar de Trujillo, además del significativo mimetismo formal y material que existe entre las albarranas octogonales de Écija y Cáceres. Pero incluso en estos casos puntuales, las lecturas que se pueden efectuar son limitadas, dado que no disponemos de fechas absolutas de prácticamente ninguna de estas construcciones almohades ${ }^{102}$, de modo que las conclusiones cronológicas precisas que se puedan extraer serán siempre subjetivas y nunca definitivas.

Con todo este discurso pretendemos reflexionar sobre la dificultad de establecer dataciones concisas en virtud de los datos formales y constructivos de los que disponemos, tanto parciales como globales, como se ha acostumbrado a realizar tan a menudo, por ejemplo, al datar la cerca de Cáceres por su parecido con la alcazaba de Badajoz. Este enfoque parcial aparecía como solución alternativa y necesaria dadas las lagunas documentales y arqueológicas existentes. Sin embargo, comprobamos cómo no aclara ni mucho menos la cuestión.

En este artículo hemos mostrado un nuevo elemento de datación para todo el conjunto, tal es el caso del fragmento de inscripción original localizado in situ en la torre de los Pozos. Aunque no lleva implícita una fecha concreta, ni ningún dato que a ella nos remita, la paternidad almohade de este testimonio no ofrece dudas, dada la correspondencia de dicha leyenda con otros ejemplos bien conocidos de la producción epigráfica muminí. Por ello, y a diferencia de los anteriores elementos de juicio aportados por la historiografía tradicional, éste que se presenta es el primero cuya filiación resulta indiscutible. Desgraciadamente, no nos permite afinar más la cronología de esta fortificación.

I0I De este modo, citar por ejemplo el caso de las fortificaciones de influencia sevillana, muy cuidadas, caracterizadas por el empleo de impostas de ladrillo en las torres, como se ve en Jerez, Badajoz, Carmona o Écija.

I02 Podemos señalar, por ejemplo, el caso de las obras realizadas en Gibraltar por 'Abd al-Mu'min en 555H/II60, tal y como se refiere en IBN SAHIB AL-SALA, Op. Cit., 1969, p. 2I, las cuales son estudiadas por A. J. SÁEZ RODRÍGUEZ y A. TORREMOCHA SILVA, "Gibraltar almohade y meriní (siglos XII al XIV)", en Actas de las VI Jornadas de Historia del Campo de Gibraltar (Gibraltar, octubre 2000), Almoraima, N²5, Algeciras, 200I, p. 186. Con independencia de casos puntuales como éste, apenas si tenemos más fechas claros acerca de construcciones defensivas almohades en al-Andalus. Así, el debate alcanza aún a ciudades tan emblemáticas como Sevilla y su cerca urbana, con tesis recientes que defienden un origen almohade, M. VALOR PIECHOTTA, Op. Cit., 199I, pp. 215 y 216; y, además, "Las defensas urbanas y palatinas", El último siglo de la Sevilla islámica (I | 47-I 248), SeviIla, 1995, p. 56; o almorávide, D. JIMÉNEZ MAQUEDA, "Algunas precisiones cronológicas sobre las murallas de Sevilla", Actas 1 Congreso Internacional Fortificaciones en al-Andalus (Algeciras, noviembre-diciembre, 1996), Algeciras, I998, pp. 333 a 336. 
De este modo, y una vez corroborada la cuestión genética de forma fiable, es menester reflexionar en torno al origen de la muralla almohade de Cáceres, incidiendo en las posibles horquillas temporales en las que se erigió y bajo qué circunstancias. Para ello procederemos a continuación a sistematizar la coyuntura histórica de la zona a finales del siglo XII.

Hemos de tener en cuenta que tras el definitivo hundimiento del poder almorávide, castellanos, leoneses y portugueses aprovecharán para afianzar posiciones y ocupar ciudades fronterizas, presionando de forma extraordinaria en una zona tan estratégica como es el norte de la actual Extremadura. Entre otras, Coria, capital de la rica comarca del río Alagón, situada entre el Tajo y el Sistema Central, cae definitivamente en manos leonesas en II42. Aunque Badajoz se someta a los muminíes en 1 I 47, éstos necesitarán más de dos décadas para afianzar su posición en al-Andalus, sobre todo en la zona que tratamos. Durante ese periodo, y con la mayoría de los recursos concentrados en la dominación del país, las autoridades almohades no dejan de perder terreno frente a la presión cristiana en todo el Garb alAndalus. En efecto, los portugueses conquistan Alcácer do Sal en II 60, y entre I I 65 y I I 66, el conocido caudillo Geraldo Sempavor, ocupará Trujillo, Santa Cruz, Évora, Cáceres, Montánchez, Serpa, Juromenha y Beja. Este último año, y tras quedar aislada, la plaza de Alcántara es tomada por Fernando II de León. A pesar de la gravedad de la situación, únicamente se producirá una reacción musulmana cuando los portugueses ataquen Badajoz en I I69. En efecto, una alianza entre almohades y leoneses consigue desbaratar el asedio y, tras ser apresados Sempavor y el propio rey Alfonso Henriques, todas las plazas que aquél había conquistado en la actual Extremadura son cedidas a castellanos y leoneses, permaneciendo la ciudad del Guadiana en poder de los Unitarios. Sólo una vez que al-Andalus se encuentre sometido bajo un mismo poder, tras la anexión definitiva del levante en 1।72, los almohades podrán dedicar sus esfuerzos a defender las fronteras y a actuar directamente contra los diferentes reinos cristianos. Así, en I I74, tras una razzia en la que se llega a asediar Ciudad Rodrigo, son recuperados los enclaves de Alcántara y, tal vez, Cáceres ${ }^{103}$. Este último lugar vuelve a ser objeto de asedio en II84, por el leonés Fernando II, tras romper treguas de cinco años con los musulmanes. Sin conseguir tomarla, levantará el asedio en junio de ese año coincidiendo con la conocida campaña musulmana de Santarem. Tras la muerte del califa en el transcurso de esta infructuosa operación militar, su hijo Abu Yusuf Ya'cub al-Mansur asume el poder y vuelve inmediatamente al Magreb para resolver los problemas que allí le reclaman. Durante los años de ausencia del nuevo califa los leoneses permanecerán inactivos, correspondiendo la iniciativa bélica a Castilla y a Portugal. Precisamente, la situación generada tras una expedición castellana sobre Magacela, Reina y las cercanías de Sevilla en I189, y la conquista de Silves por los lusos en fechas simultáneas, provocará el retorno del califa a la península al año siguiente. Una vez firmadas treguas con Castilla, y renovadas con León, sus tropas efectúan razzias sobre territorio portugués sin obtener resultados significativos. Sin embargo, en | 19 | se tomará Alcácer do Sal y Silves sin producirse ninguna respuesta militar del monarca Sancho I ${ }^{104 .}$

Tras la victoria de Alarcos, en I 195, y durante dos años consecutivos, I 196 y I I97, al-Mansur y su ejército realizarán sendas campañas militares, más aparatosas que efectivas, en las que se eliminará la avanzada cristiana en tierras extremeñas. Así, en la primera se conquistarán Montánchez, Santa Cruz, Trujillo y, posiblemente, Majadat al-Balat, restableciéndose la frontera en la zona del Tajo correspondiente a la actual Extremadura. El califa regresará definitivamente a África en I197, con

I03Consúltese, F. HERNÁNDEZ GIMÉNEZ, "Los caminos de Córdoba hacia noroeste en época musulmana", al-Andalus, XXXII, 2, Madrid-Granada, 1967, pp. 325 a 329.

I04Refiere esta cuestión, A. HUICI MIRANDA, Historia política del imperio almohade, tomo I, Tetuán, 1956, pp. 355 y 356. 
treguas firmadas con Castilla, León y Portugal, que garantizarán la paz más duradera conseguida entre almohades y el conjunto de reinos cristianos. Lo suficiente como para permitir a los Unitarios refortificar varios de los enclaves en su poder, los recientemente recuperados y los ya dominados años atrás. Realmente, hasta ese momento no se produce una conjunción de condiciones políticas y militares tan propicias como para poder acometer una reforma edilicia de tal envergadura.

Incidiendo en este punto, creemos necesario recapitular y hacer ciertas reflexiones sobre la génesis del recinto defensivo que nos ocupa, situándolo dentro de este convulso contexto y proponiendo nuevas hipótesis de interpretación. En primer lugar, es evidente la improbabilidad de que las obras de reforma almohade de la cerca cacereña fuesen llevadas a cabo antes de 1 165, dada la especial coyuntura que sufría el occidente andalusí; además, ninguna intervención fortificadora tan temprana ha sido atestiguada en este territorio ni por la arqueología ni por las fuentes. Sólo tenemos una fecha más o menos concreta para las obras de reforma de la alcazaba de Badajoz y su recinto general, presumiblemente realizadas entre 1168 y I 169 con carácter de urgencia tras los acontecimientos antes reseñados ${ }^{105}$. Esta circunstancia no justifica intervenciones coetáneas en otros recintos próximos. En cualquier caso, la fecha de II 74 aparece como término post quem para la construcción de las nuevas defensas cacereñas. En el periodo que abarca hasta I 196 no creemos probable que se emprendiera una obra de tal magnitud, al haber constituido Cáceres, junto con Alcántara, una plaza musulmana prácticamente aislada y rodeada por enclaves de frontera enemigos, los cuales no son recuperados hasta ese último año ${ }^{106}$. Al margen de tales argumentos, también conocemos la debilidad militar del reino leonés, que no se encon- tró durante esas décadas en condiciones de realizar grandes campañas militares.

La situación cambia a partir de Alarcos, una vez restablecida la línea del Tajo con el control de importantes plazas situadas a mediodía del mismo, y el retroceso de las posiciones cristianas. Pensamos que la intervención llevada a término en Cáceres no pudo ser concebida como un hecho puntual, sino como una más dentro de un amplio programa de refortificación de la frontera en este sector. Conviene recordar que, en esta nueva situación, las líneas de avituallamiento provenientes de la cuenca del Guadiana estaban aseguradas, por lo que es posible mantener los núcleos de vanguardia bien guarnecidos y suministrados. La reforma de las defensas cacereñas pretendería, no sólo dotar a las mismas de técnicas de flanqueo más desarrolladas, sino, principalmente, ejecutar una redistribución del espacio que incluyera un vasto recinto o albacar donde acantonar los aparatosos ejércitos que solían movilizar los califas almohades. Es así como esta plaza se constituiría en el principal campamento de frontera de todo este sector, etapa final de una serie de fortificaciones que acogerían a las tropas norteafricanas desde su desembarco en el Estrecho. Aunque, como refiriera al-Idrisi, este carácter de reunión ya se daba en la primera mitad del siglo XII, la coyuntura propiciada por la recuperación almohade de finales de esa centuria en el Garb al-Andalus justifica el desarrollo de la plaza como gran centro receptor de tropas, que consolidara la frontera $y$, sobre todo, sirviera de punto de partida para las expediciones contra tierras cristianas. Su importancia, curiosamente silenciada por las fuentes, queda patente en el hallazgo del epígrafe de carácter oficial localizado en la torre de los Pozos (véase supra), cuya excepcionalidad refrenda la autoría de la obra y el especial cuidado puesto en ella. Esta amplia

I05Aporta como fecha el año 564 de la Hégira (5 de octubre de I 68 / 24 de septiembre de I I69), IBN SAHIB AL-SALA, Op. Cit., 1969, p. 149.

I06Pensemos no sólo en lo complicado que hubiera resultado rehacer las defensas cacereñas en esa coyuntura, sino, además, en lo poco práctico que hubiera sido desde el punto de vista estratégico. Es más, incluso suponiendo que Cáceres estuviera fuertemente pertrechada cuando era una plaza aislada, ¿cómo se habrían podido mantener las líneas de avituallamiento sin exponerse al fácil hostigamiento desde enclaves como Montánchez? 
reforma nacería en la nueva, aunque efímera, situación de pujanza almohade con una finalidad netamente ofensiva ${ }^{107}$. Pensamos que las defensas prealmohades serían lo suficientemente sólidas para resistir asedios puntuales como el de I |84, cumpliendo su función defensiva y eventualmente ofensiva. Sin embargo, la situación creada a finales del siglo XII exigía acentuar el especial carácter del enclave, vinculado a la necesidad de concentrar grandes ejércitos, y continuar, probablemente, con las campañas que la nueva situación ventajosa posibilitaría. Es así cómo se reformaría, mejorando las defensas, el antiguo recinto islámico.

Comentábamos que estas nuevas defensas de Cáceres no podían entenderse si no formando parte de un programa establecido de consolidación de las construcciones militares que configuraban la frontera en zona tan críti$\mathrm{ca}^{108}$. De este modo, y aunque esta plaza adquiriera un papel especializado y predominante, el resto de enclaves recuperados tras la campaña de II96 también recibirán atenciones puntuales por parte de las autoridades muminíes, aunque destinadas principalmente a consolidar sus estructuras y a mejorar su valía defensiva. A ese momento corresponderá la albarrana del albacar de Trujillo ${ }^{109}$, de significativa similitud morfológica con alguna torre de la cerca cacereña, el aljibe del castillo de Montánchez, claramente almohade, y las importantes reformas realizadas con hormigones de cal vistas en al-Balat ${ }^{110}$. Recientes estudios sobre las defensas de Santa Cruz parecen haber identificado una torre albarrana situada en el frente más accesible, y que también correspondería a este momento 'I'. Además, recordemos que la política de refortificación emprendida por al-Mansur tras la toma de determinadas plazas militares situadas en el occidente andalusí ya se documenta en las nuevas obras que acomete a continuación de la recuperación de Alcácer do Sal en 1191.

Tampoco debemos olvidar que en el período comprendido entre II 74 y I 196 el debilitado reino de León apenas si constituía un serio peligro para los almohades; inferior, desde luego, al que suponían los de Castilla y Portugal, mucho más agresivos. Es sintomático que en ese lapso temporal los Unitarios no emprendiesen ninguna ofensiva sobre León. Sin embargo, en los años previos a Alarcos, este reino procede a la repoblación y a la consolidación de posiciones en la Trasierra, circunstancia que empieza a constituir una seria amenaza para los enclaves musulmanes a mediodía del Tajo. De este modo, es posible que la intención de las autoridades almohades, al emprender la obra de Cáceres, fuese la de crear una base desde la cual lanzar ataques para debilitar las posiciones leonesas y evitar su consolidación, estrategia que vendría reforzada por la posición ventajosa que adquieren los musulmanes tras I196.

Por todo ello, proponemos una nueva hipótesis sobre la cronología de la cerca cacereña. Tomaremos para ello un margen temporal comprendido entre 1196, fecha de la campaña que recupera las principales plazas extremeñas al sur del Tajo, y los inicios de la primera década del siglo XIII, debido al rápido declive que experimenta el poder almohade a partir de entonces, y que coincide con la falta de importantes expediciones militares antes y después de la

I07Asumiría un papel análogo al que cumplió Gormaz durante el califato omeya, al actuar como gran campamento y punta de lanza donde acantonar los ejércitos que acudían periódicamente a realizar campañas en tierras cristianas.

I08Aunque nos refiramos a otro entorno geográfico y estratégico, no deja de ser significativo el reforzamiento que sufren las defensas de Calatrava la Vieja a manos almohades a partir de I195; véase, M. RETUERCE VELASCO y M. A. HERVÁS HERRERA, Op. Cit., 2002, p. 316.

I09Se apunta un origen posiblemente almohade en J. LAFUENTE y J. ZOZAYA, "Algunas observaciones sobre el castillo de Trujillo". España entre el Mediterráneo y el Atlántico. Actas del XXIII Congreso Internacional de Historia del Arte, Granada, I973, II, Granada, 1976, p. 120

I I OConsúltese, S. MARTíNEZ LILLO y L. SERRANO-PIEDECASAS FERNÁNDEZ, "El poblamiento andalusí en al-Tagr al-Awsat (Marca Media). El Mundo Omeya", Castillos y territorio en al-Andalus (Berja, 1996), Granada, 1998, pp. 80 a 85.

I I I Información inédita que agradecemos a la arqueóloga Sophie Gilotte. 
derrota de las Navas de Tolosa. De este modo, la desaparición de las grandes y costosas levas califales anularía la necesidad funcional propuesta para la última obra islámica de Cáceres.

\section{CONCLUSIONES}

El estudio exhaustivo de estas estructuras defensivas almohades, a través de una triple vertiente (constructiva, formal y funcional), nos ha permitido extraer distintas conclusiones que permiten conocer un poco mejor el carácter particular de las mismas en cuanto tipo defensivo y su carácter general en relación con el resto de la producción militar almohade. Este análisis se ha puesto en valor confrontándolo con los dispersos y poco prolijos datos que, sobre el tema, nos aportan tanto los trabajos arqueológicos como la historiografía tradicional.

Cabe hacer mención, en primer lugar, a los aspectos constructivos, los cuales apenas si añaden alguna novedad significativa acerca del conocimiento que disponemos sobre este periodo en concreto. Todo lo más, la aseveración de que la técnica del tapial empleada sistemáticamente en el recinto de Cáceres, concuerda en su puesta en obra y en los hormigones usados con lo estudiado en la mayoría de los recintos datados tradicionalmente como almohades. En todo caso, esta cuestión no hace si no reafirmar la homogeneidad y el talante de estandarización que adquiere este sistema edilicio en al-Andalus durante los siglos XII y XIII. Aspectos como las proporciones de las hormas, disposición de juntas oblicuas, número de agujas por cajón y tantos otros elementos constructivos apenas si se prestan a regularizarse mediante recios cánones, no sólo con relación a otras fortificaciones, si no, incluso, dentro de una misma obra, tal es nuestro caso. En general, todo lo concluido sobre modulaciones debería tratarse más bien como un expediente local, aun a pesar de existir un substrato tecnológico común conocido por los distintos constructores de al-Andalus en ese momento.

Estas tapias hormigonadas suelen combinarse de forma habitual con otros materiales, for- mando, sobre todo, altos zócalos para dichas tapias. Dos son los aparejos pétreos que identificamos en numerosos basamentos: o bien sillería de acarreo presumiblemente romana, o bien mampostería, cuando es obra nueva realizada ex profeso. Encadenados de mampuesto en las esquinas de torres, como vemos en la torre de los Pozos, son más bien excepcionales.

Otros elementos, como las agujas partidas, que se revelan idóneas para resolver la construcción de muros de gran potencia, al igual que las almohadillas practicadas entre merlones en los parapetos, empiezan a constituir soluciones singulares que se incorporan definitivamente al léxico edilicio de las obras de tapia en fortificaciones almohades. Sin embargo, la costumbre de enfoscar con mortero de cal únicamente pretiles y merlaturas constituye una novedad no estudiada hasta ahora en el recinto que nos ocupa y en otros coetáneos. De este modo, hemos podido identificarla en las cercas de Niebla y Gibraltar, siempre combinada con la resolución del resto del alzado mediante cintas de cal trazadas sobre las juntas entre cajones.

$\mathrm{Si}$, como decimos, existe una evidente uniformidad constructiva, no así de modulación, en la obra muminí de Cáceres, similar cuestión podemos referir al estudiar los distintos dispositivos de flanqueo que conservamos. Como bien es sabido, esta cerca se caracteriza por la proliferación de torres albarranas de, aparentemente, común morfología: grandes construcciones troncopiramidales con cámara al nivel del paso albarrano; sólo dos de ellas responderán al modelo octogonal. Los espigones suelen estar horadados en su base por uno o dos arcos, y, en la mayoría de las torres correspondientes al frente occidental del recinto, apoyan en pequeños cubos islámicos prealmohades. Sin embargo, la forma de abovedar las estancias de estas albarranas, mediante soluciones bien dispares, no deja de resultar desconcertante sin mediar ningún motivo coyuntural que evite una lógica seriación. Al igual que se mencionaba para el caso de las sutiles variaciones que encontrábamos en la puesta en obra de las tapias, esta última cuestión parece confirmar el trabajo simultáneo de diferentes cuadrillas de alarifes o equipos de constructores, 
que, aunque regidos por normas establecidas, parecen adoptar criterios independientes. La existencia de distintos equipos quedaría además justificada por lo vasto del recinto y la lógica celeridad que este tipo de trabajo demanda.

Esa homogeneidad general que se desprende del estudio de todas las estructuras muminíes de Cáceres denota un único impulso constructivo a la hora de poner en obra el conjunto del recinto. Sobre otras defensas prealmohades, que a su vez aprovechan algo de otro anterior preislámico, se reforman las estructuras defensivas generales. El esquema resultante, casi mimético al ya existente, ciñe una colina cuyo punto más alto coincide con la situación de la alcazaba, que en esta fase definitiva ocupará una posición eminentemente central. La hipótesis organizativa que planteamos viene a definir una concepción tripartita del espacio intramuros: zona para la población o madina propiamente dicha, alcazaba y albacar, originándose una nueva redistribución urbana en periodo almohade. Sin embargo, y como se ha repetido en estas líneas, sin una intervención arqueológica exhaustiva sobre el conjunto de la cerca poco más podemos avanzar acerca de estas y otras teorías.

Otro elemento que, por su singularidad, debemos mencionar dentro de esta organización definitiva de la muralla cacereña es el baluarte que se conoce con el nombre de torre de los Pozos. Éste aparece como espolón oriental de la alcazaba, y su especificidad morfológica dentro de un conjunto tan homogéneo parece denotar una funcionalidad particular. La importante proyección al exterior del conjunto de sus defensas, justo en el punto de mayor proximidad a la rivera del Marco, unido a la curiosa toponimia de cada uno de los distintos elementos (vinculada siempre con el agua), tal vez propongan una finalidad relacionada con el aprovechamiento hídrico y la aguada.

Esta importante obra de reforma y ampliación realizada en Cáceres parece identificarse en su concepto con otras similares que en periodo almohade se realizan en al-Andalus: sirvan como ejemplo los casos de Tarifa, Gibraltar, las alcazabas de Sevilla, y, posiblemente,
Jerez y Andújar. En todos estos recintos se adaptan grandes vacíos cercados e independientes del resto de la estructura urbana con el fin de acoger grandes contingentes militares. El establecimiento de ese albacar parece definir por si mismo la finalidad y principal criterio funcional de la fase almohade de la cerca cacereña, adoptando un uso campamental que ya apuntara Fernando Valdés en su momento. Resulta evidente que la mejora de los elementos de flanqueo también preocupó a estos constructores, al unificar todo el conjunto bajo idéntico esquema poliorcético.

El estudio de la especial coyuntura política y militar en el territorio de frontera que nos ocupa justifica ampliamente la función propuesta. Sin embargo, pensamos que la cronología merece un debate más profundo para evitar datas tradicionales que pecan a veces de poco rigurosas. En este sentido planteamos una nueva interpretación que relaciona la fase almohade de este recinto con el impulso constructor del califa Ya'cub al-Mansur. De este modo, la campaña de 1196, en la cual se dominan los más importantes enclaves situados al sur del Tajo en la actual Extremadura, parece venir acompañada por un especial impulso de refortificación, tal y como comprobamos en Trujillo, Montánchez, Santa Cruz o Majadat al-Balat. La obra de Cáceres formaría parte de esta política, aunque con una finalidad muy específica, directamente relacionada con el acantonamiento final de tropas en su tránsito hasta tierras cristianas. Así, esta funcionalidad eminentemente ofensiva con la que fue concebido el recinto reformado, jamás llegó a cumplir su cometido, debido a que las grandes levas promovidas por las autoridades muminíes no volvieron a operar en este sector tras la muerte del califa en II99. En cualquier caso, la importancia de la plaza y el especial interés puesto en su reconstrucción por el estado almohade quedan refrendados por la presencia de un interesante epígrafe identificado en la torre de los Pozos. Este testimonio representa uno de los escasos ejemplos estudiados en fortificaciones andalusíes vinculados a la presencia de la autoridad almohade, e incorpora un mensaje de tipo religioso acorde al nuevo pensamiento rigorista del movimiento norteafricano. 


\section{AGRADECIMIENTOS}

Existe un grupo de personas cuya inestimable y desinteresada colaboración ha sido fundamental para la realización de este trabajo. Éstos son: María Antonia Martínez Núñez, Manuel Acién Almansa, Miguel Matas Cascos, Enrique Cerrillo Martín de Cáceres, Javier Sellers
Bermejo, Lola García Oliva, Fernando González Solano, Paqui López Calvache, Jaime Naranjo, Raimundo Holgado y Carlos Guardiola. Tampoco nos podemos olvidar de las personas que nos han facilitado el acceso a las torres y viviendas anexas, así como de aquellos que han colaborado en la toma de datos. A todos ellos va dedicada nuestra más sincera gratitud. 


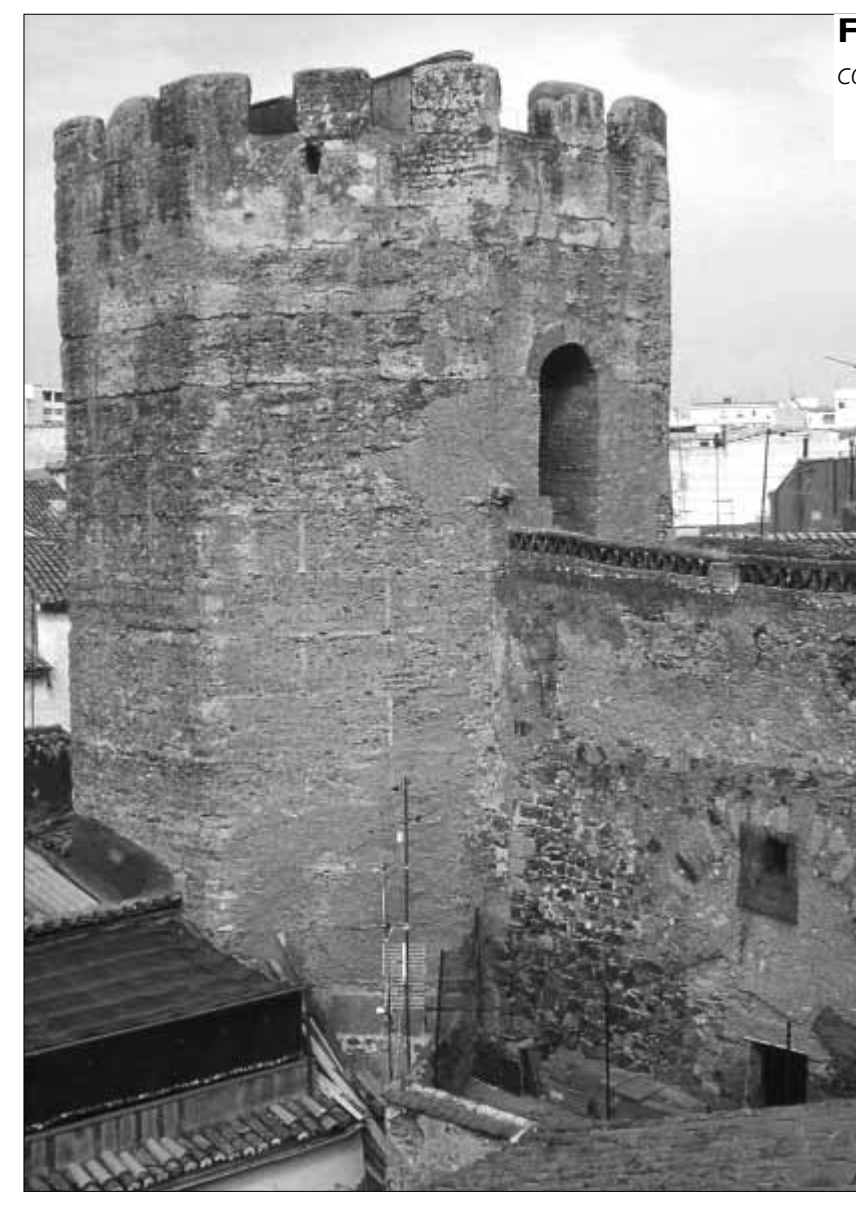

Fig. I. Vista general de la torre

conocida como Redonda desde el este

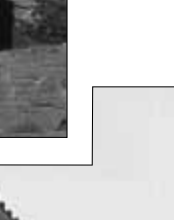
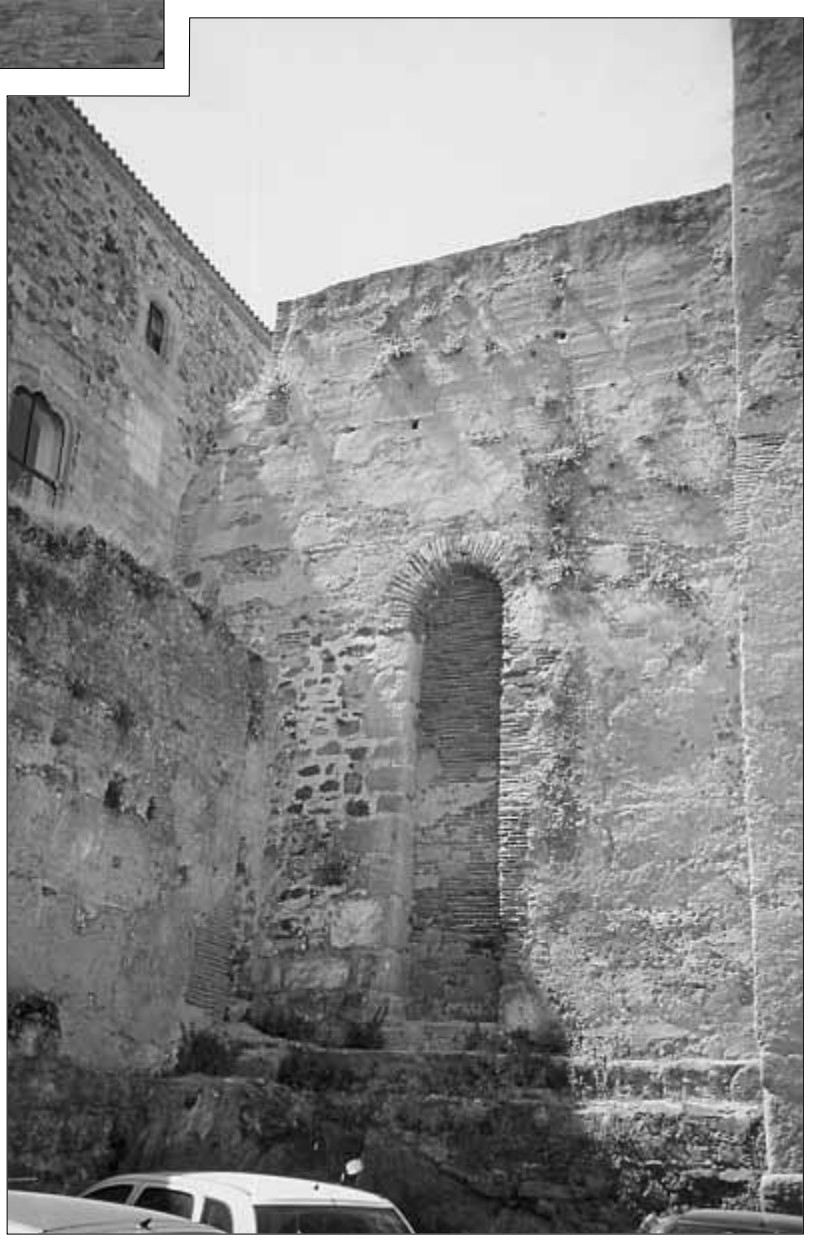

Fig. 2. Detalle del espigón y arco correspondiente en la torre del Horno 


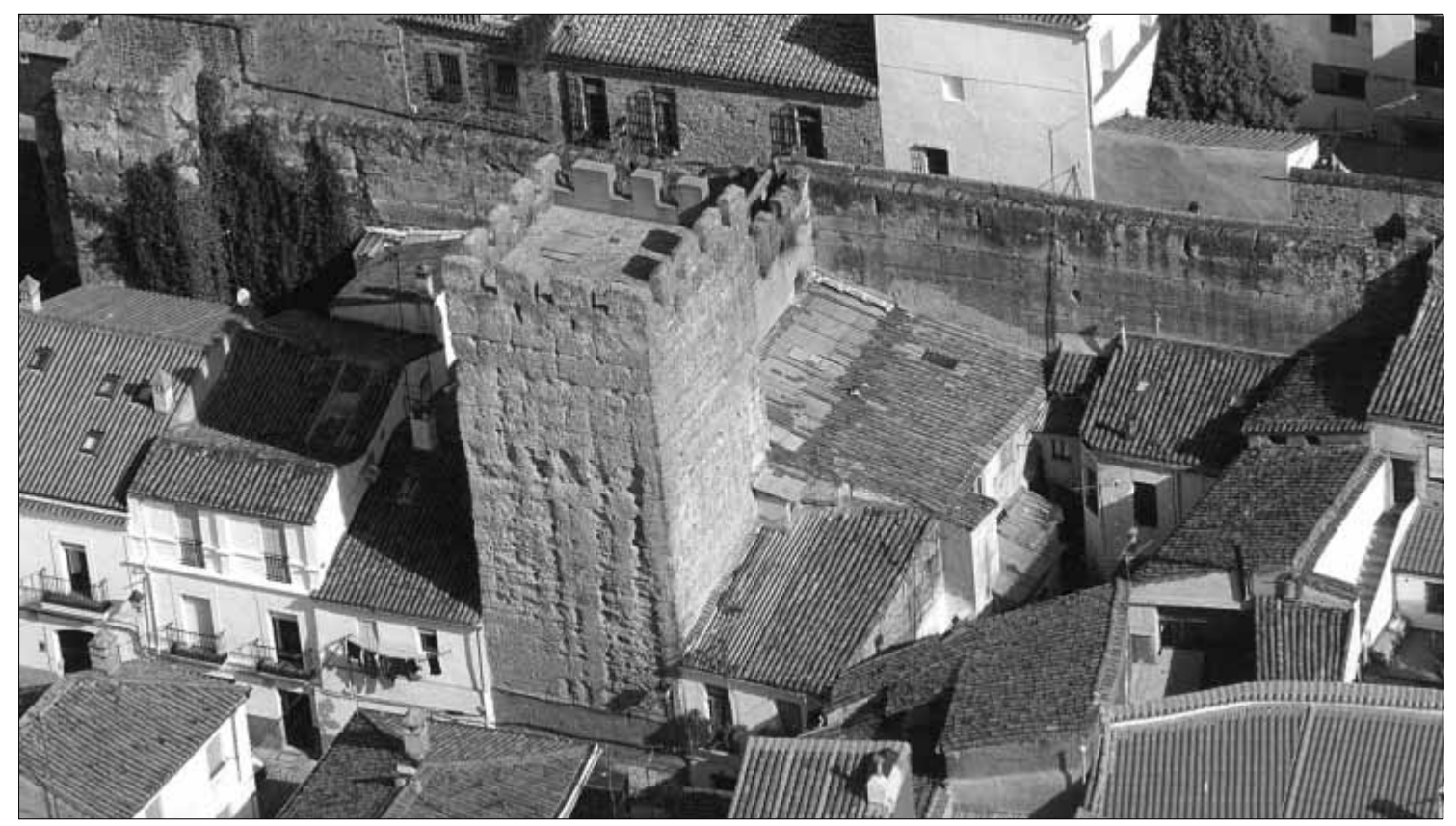

Fig. 3. Vista aérea de la torre del Aver, lienzos inmediatos y cubo del Padre Rosalío (foto cedida por M.Matas Cascos)

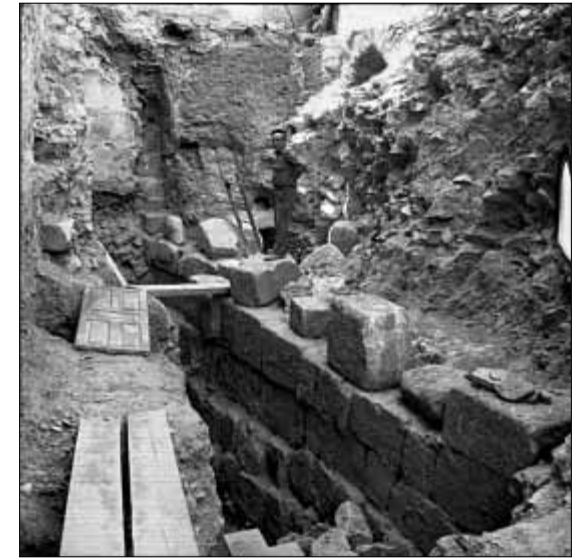

Fig. 4. Imagen de los restos exhumados en la esquina NO del recinto cacereño en 1974. Obsérvese el basamento de sillares graníticos. (Foto cedida por E. Cerrillo Martín de Cáceres)
Fig. 5. Vista general de la torre del Horno desde la Plaza de las Piñuelas

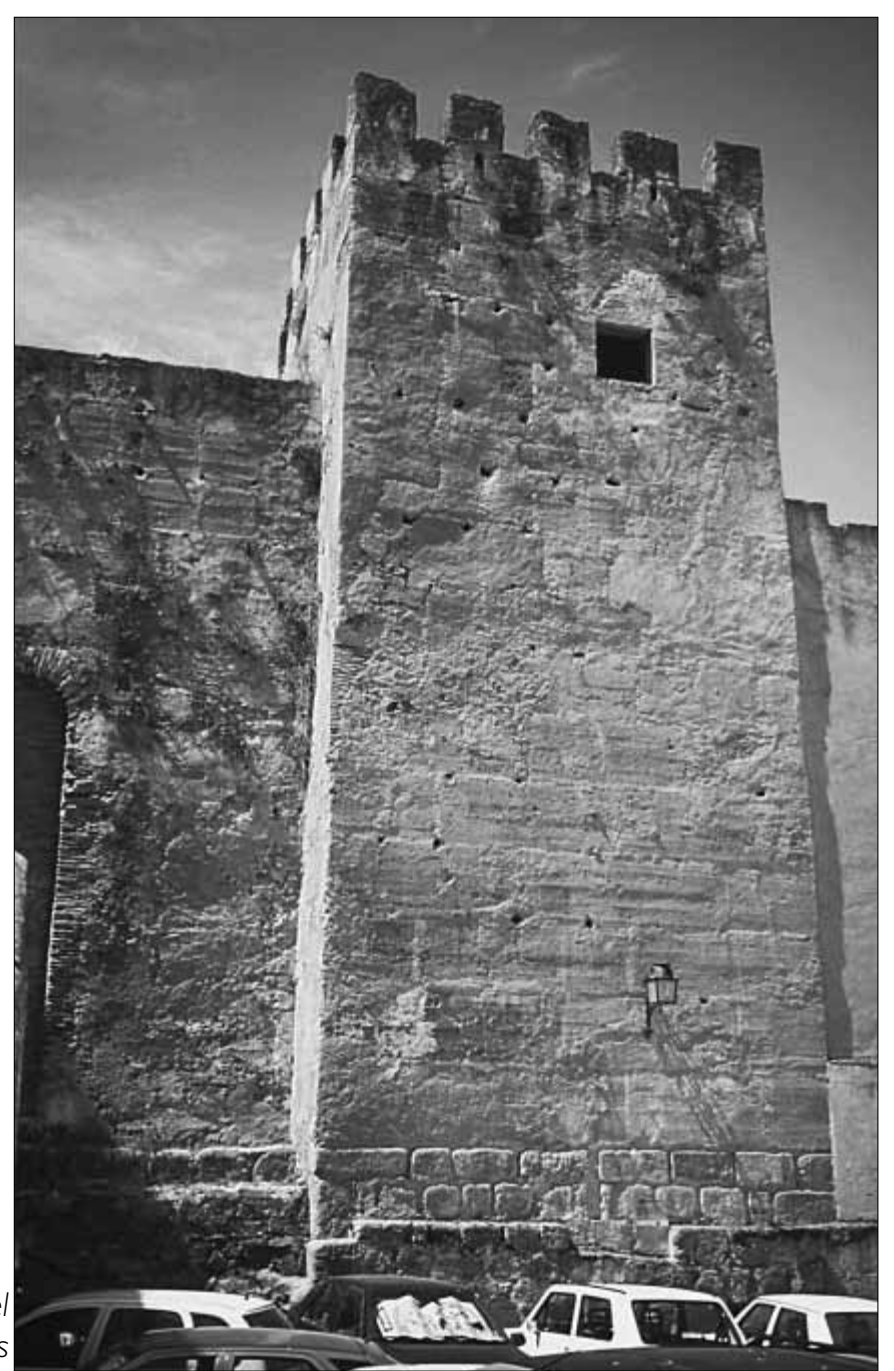



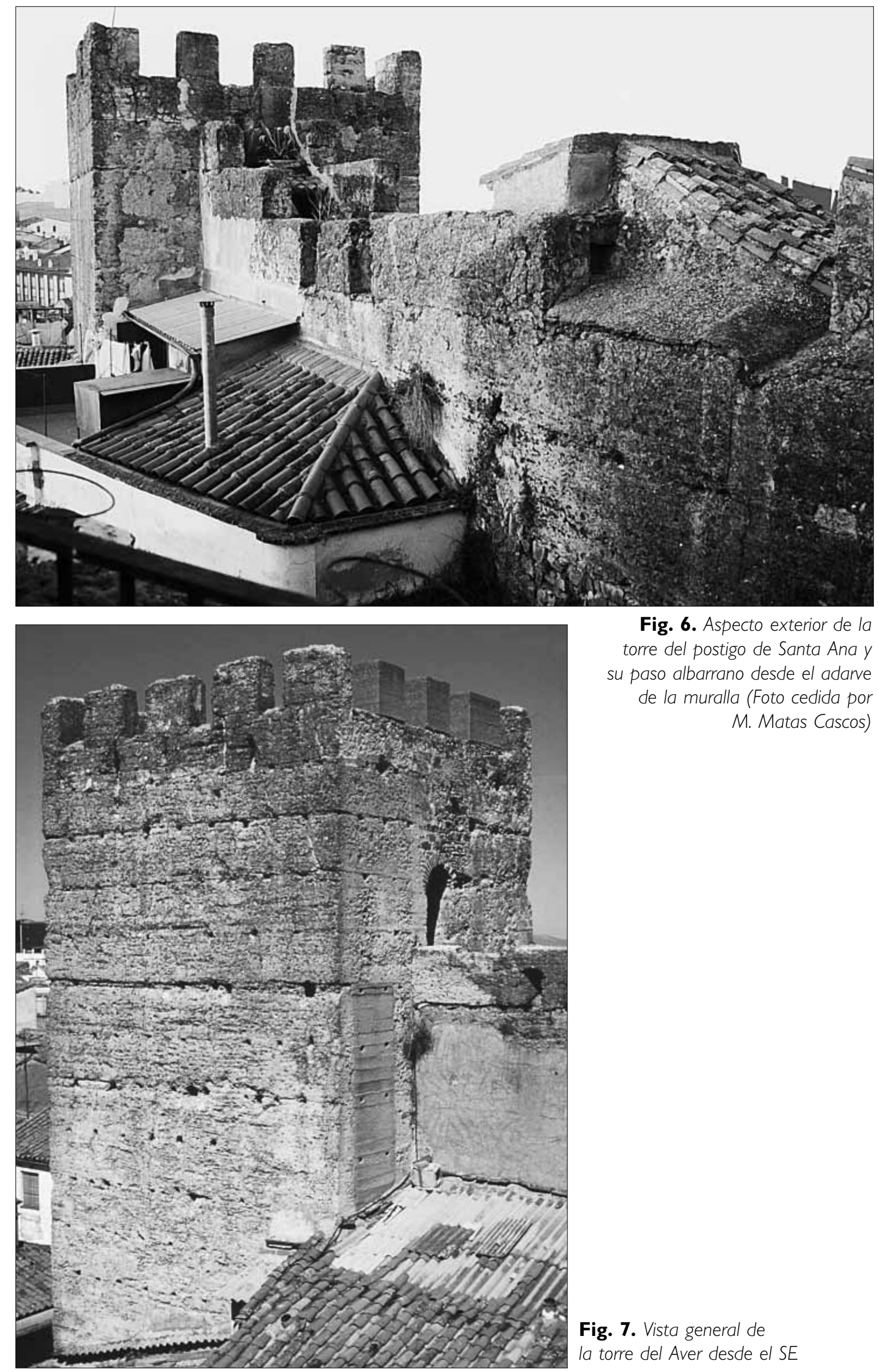

Fig. 6. Aspecto exterior de la torre del postigo de Santa Ana y su paso albarrano desde el adarve de la muralla (Foto cedida por M. Matas (ascos)

Fig. 7. Vista general de

la torre del Aver desde el SE 


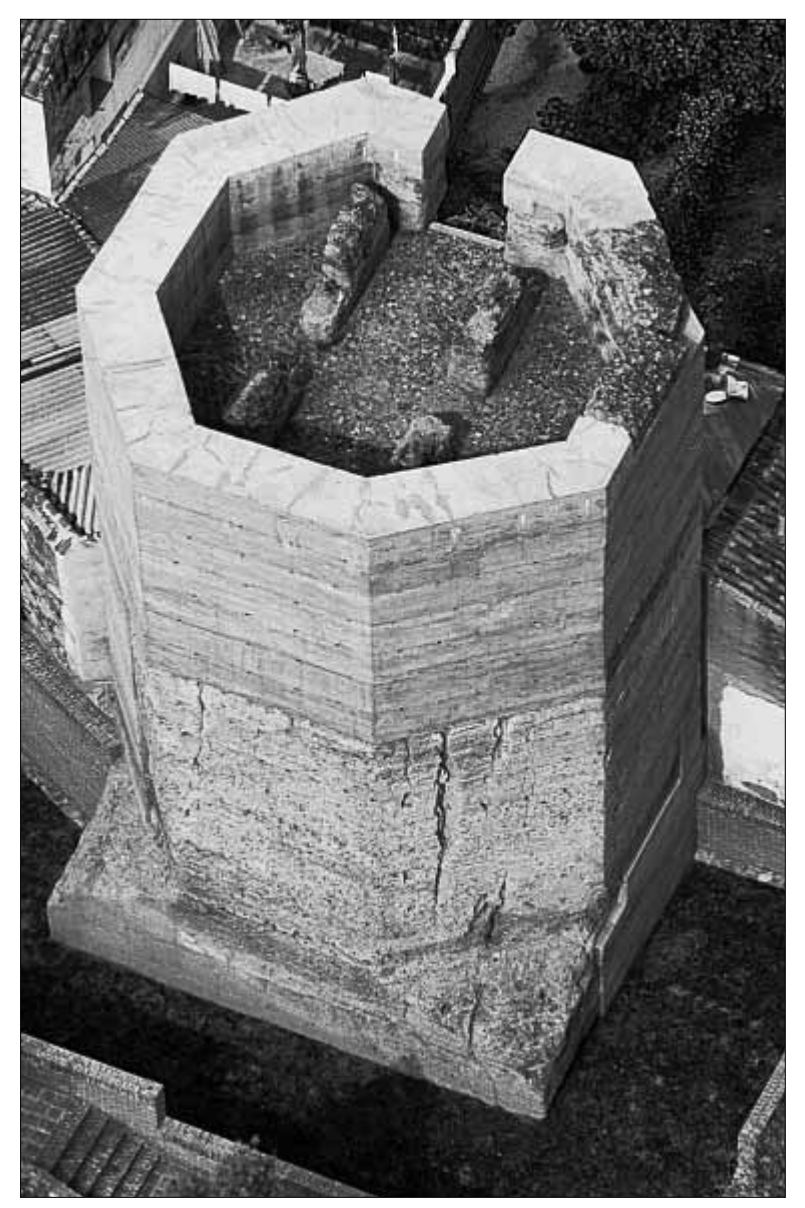

Fig. 8. Vista aérea de Torremochada. Obsérvese el resultado de la última intervención restauradora (Foto cedida por M. Matas Cascos)

Fig. 9. Aspecto de la torre septentrional de la calle Caleros desde el $E$

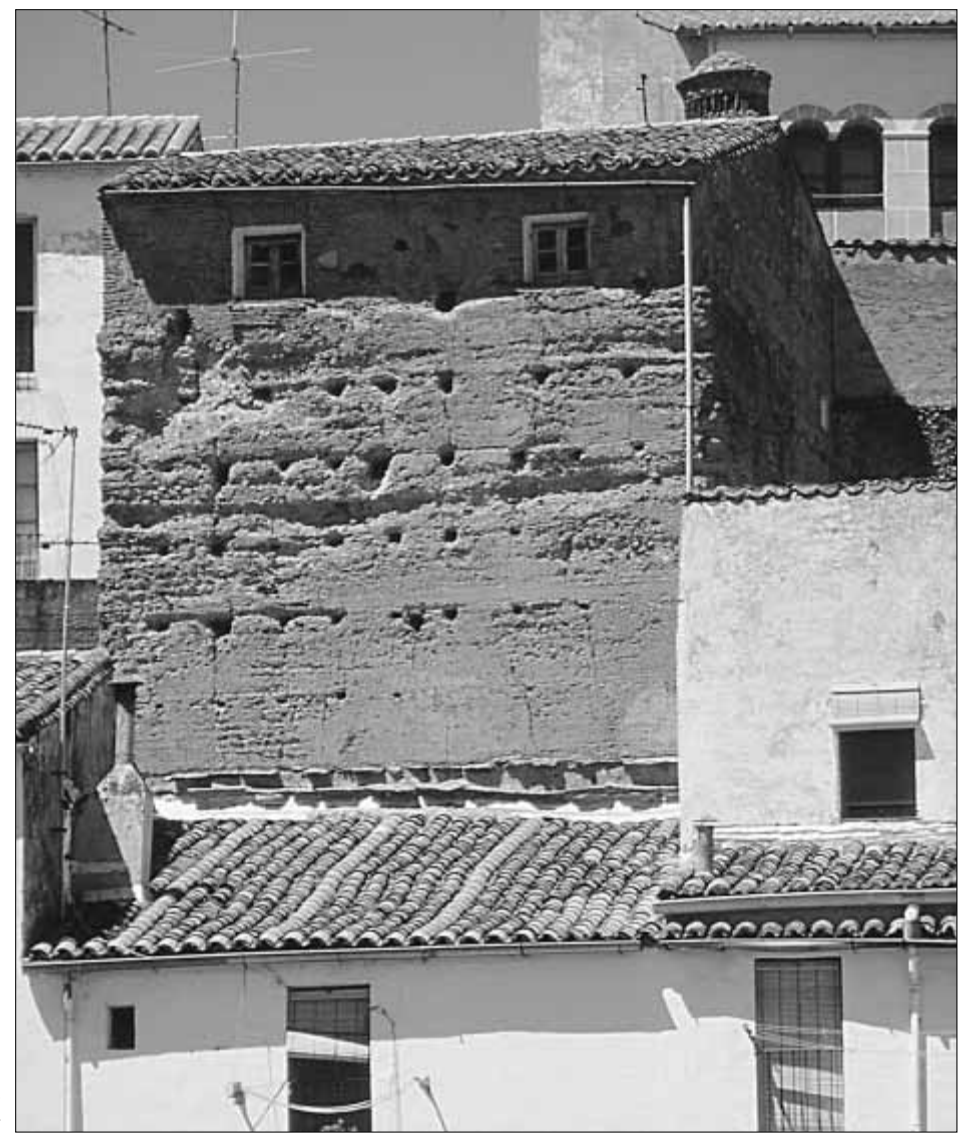


Fig. I 0. Vista occidental del cubo de la calle Padre Rosalío
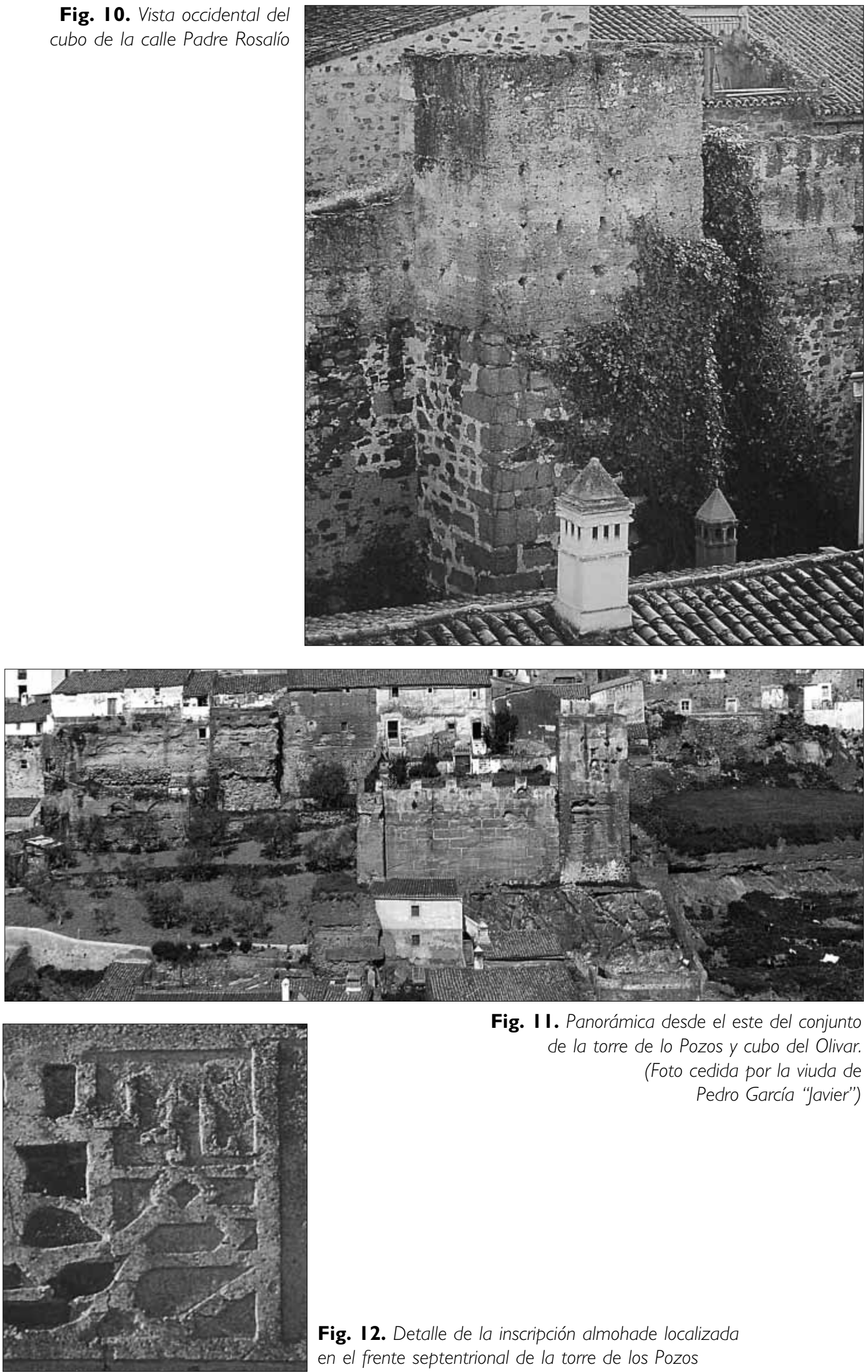

Fig. I I. Panorámica desde el este del conjunto de la torre de lo Pozos y cubo del Olivar. (Foto cedida por la viuda de Pedro García "Javier")

Fig. I2. Detalle de la inscripción almohade localizada en el frente septentrional de la torre de los Pozos 


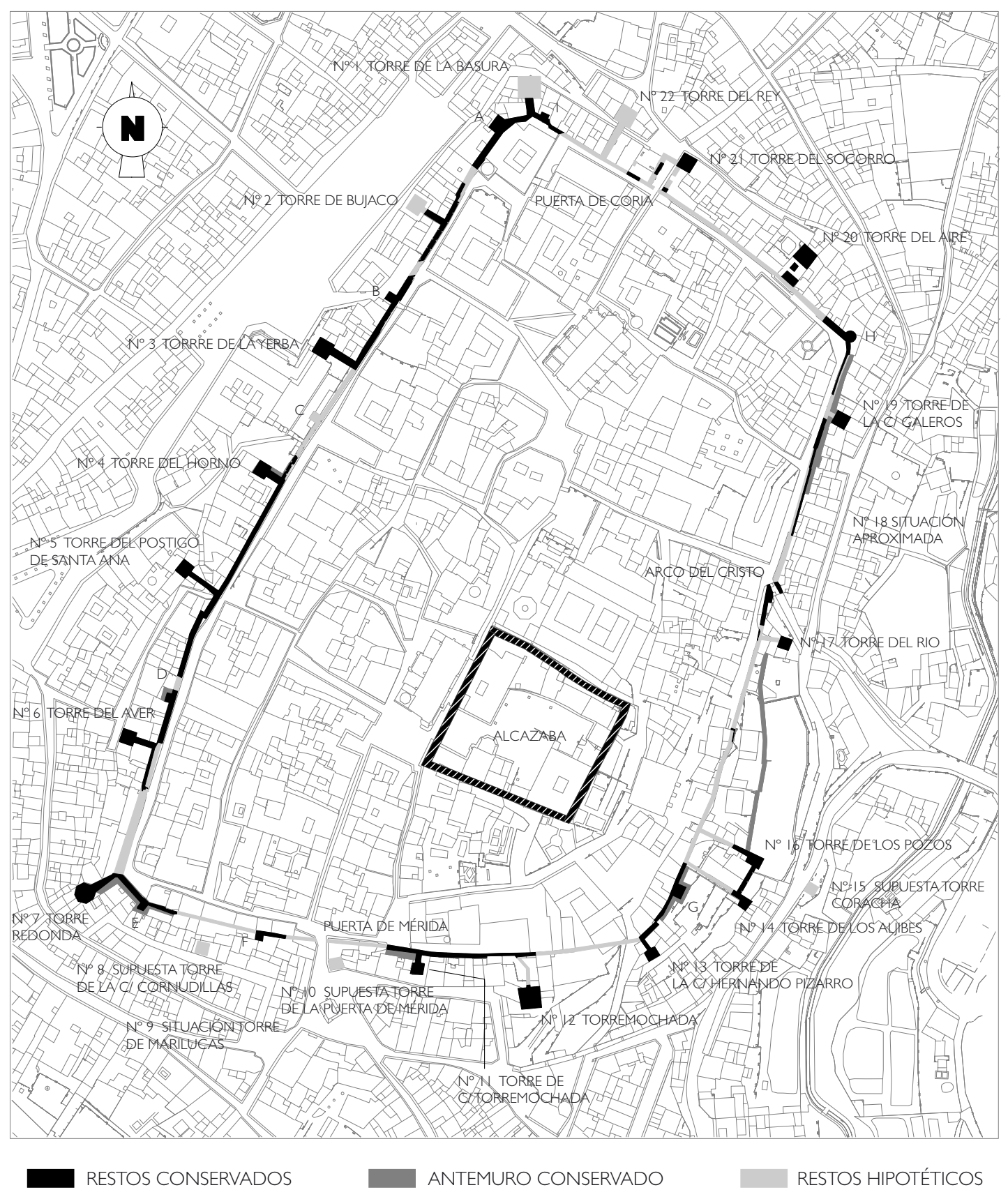

Lam. I. Planta general del recinto almohade de Cáceres. E I/2500 


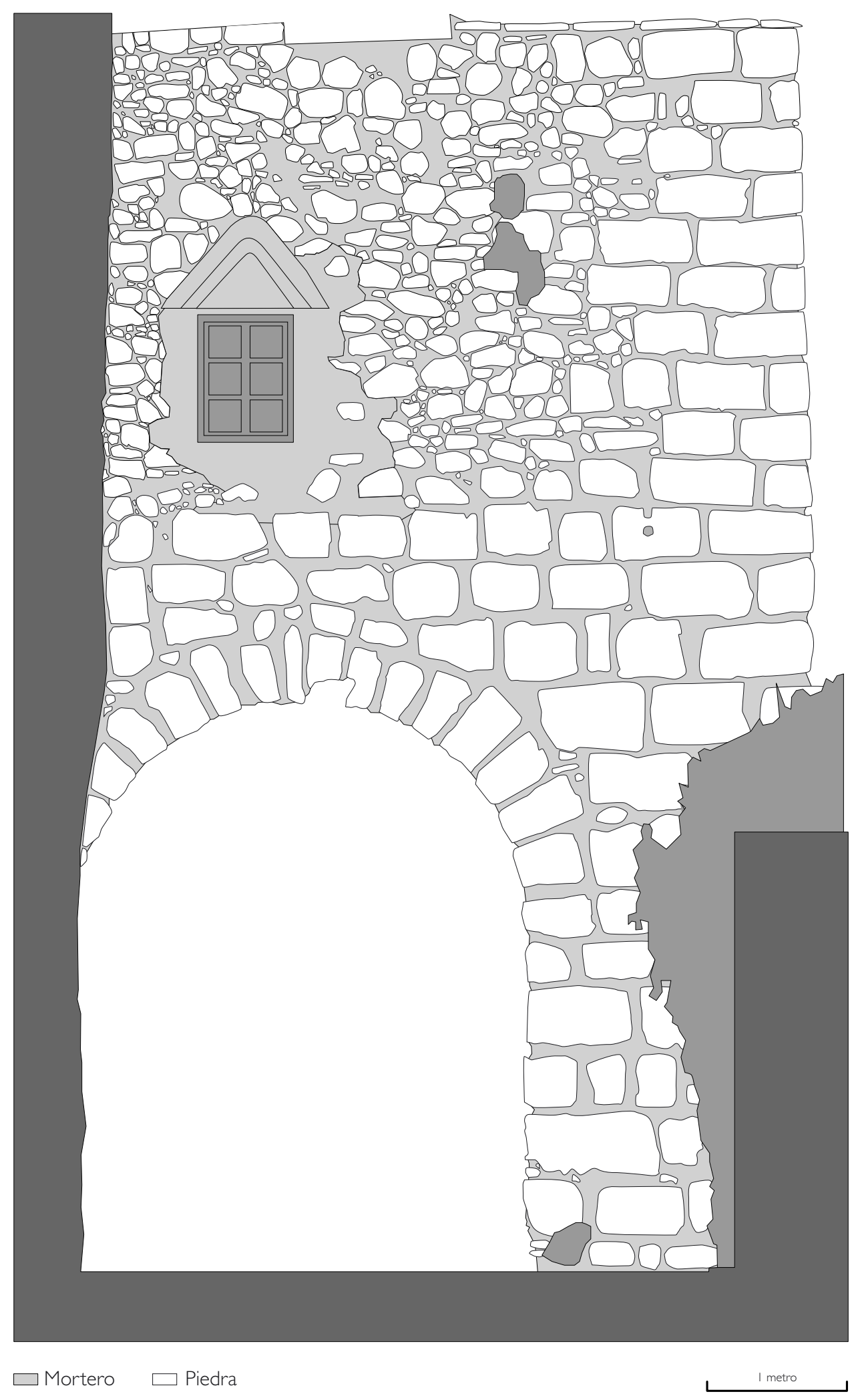

Lam. 2. Restitución fotogramétrica del frente $E$ del Arco del Cristo. Escala gráfica 


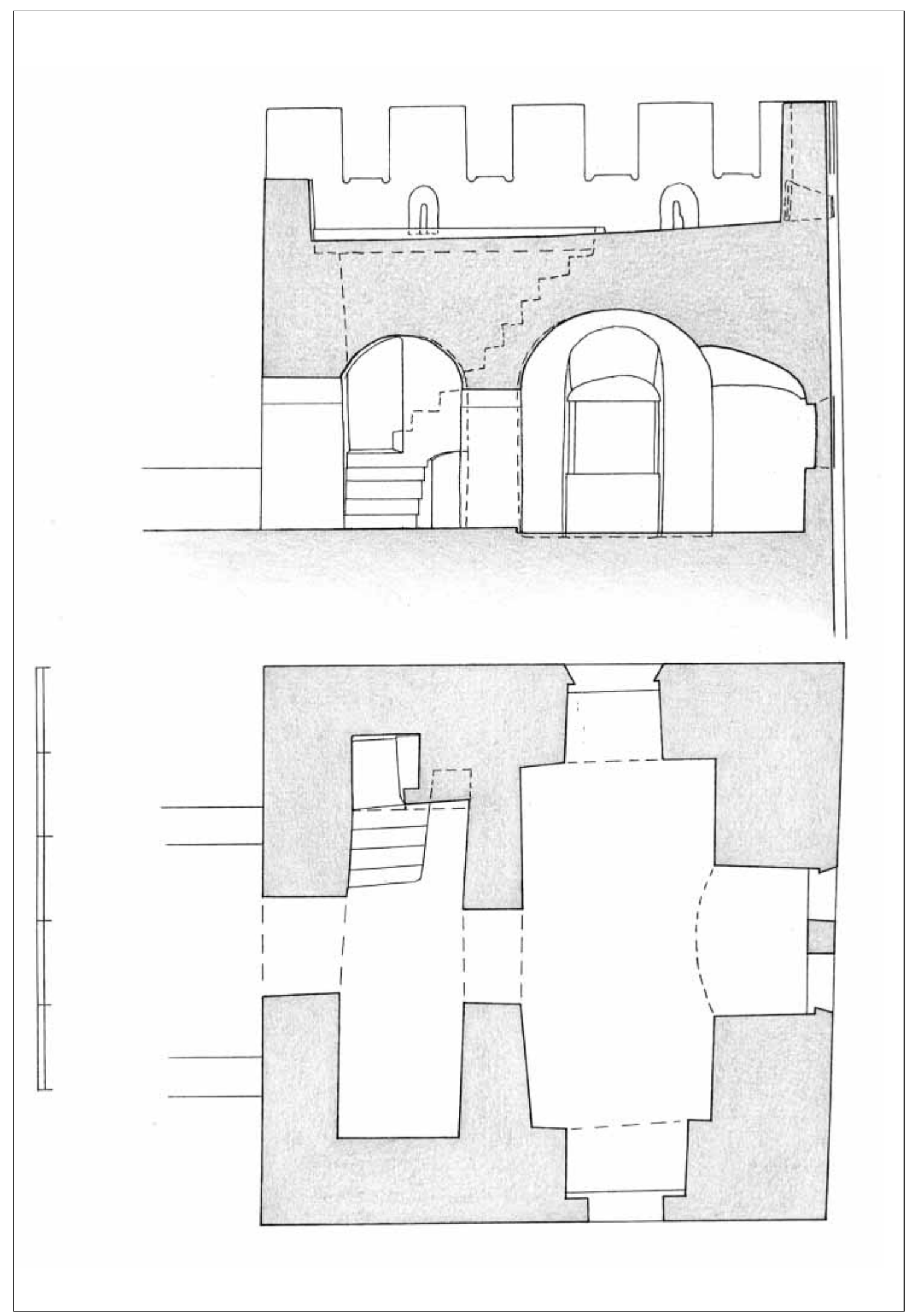

Lam. 3. Planta y sección de la cámara de la torre del Horno. Escala gráfica 


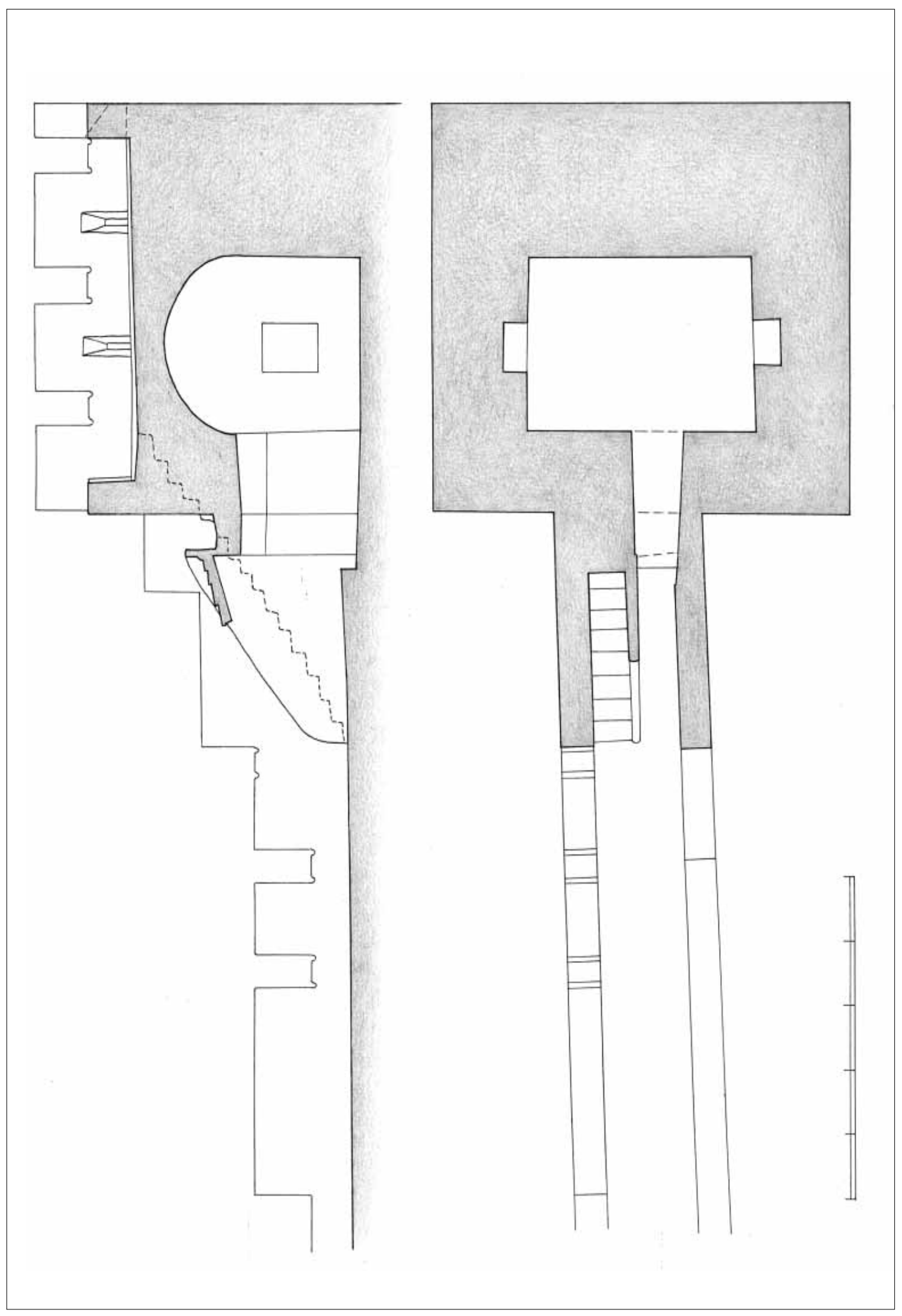

Lam. 4. Planta y sección de la cámara de la torre del Postigo de Santa Ana. Escala gráfica 


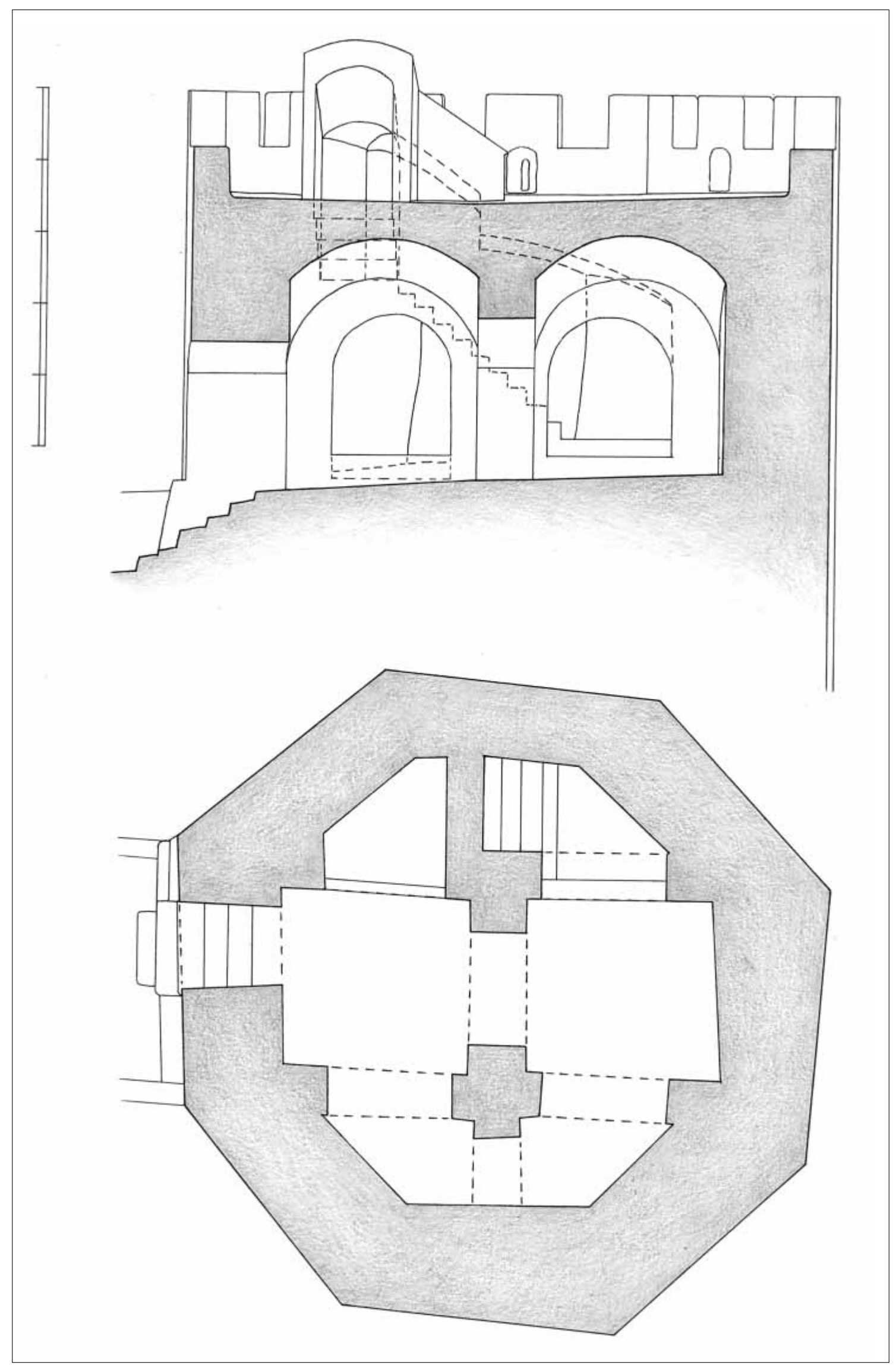

Lam. 5. Planta y sección de la cámara de la torre Redonda. Escala gráfica 


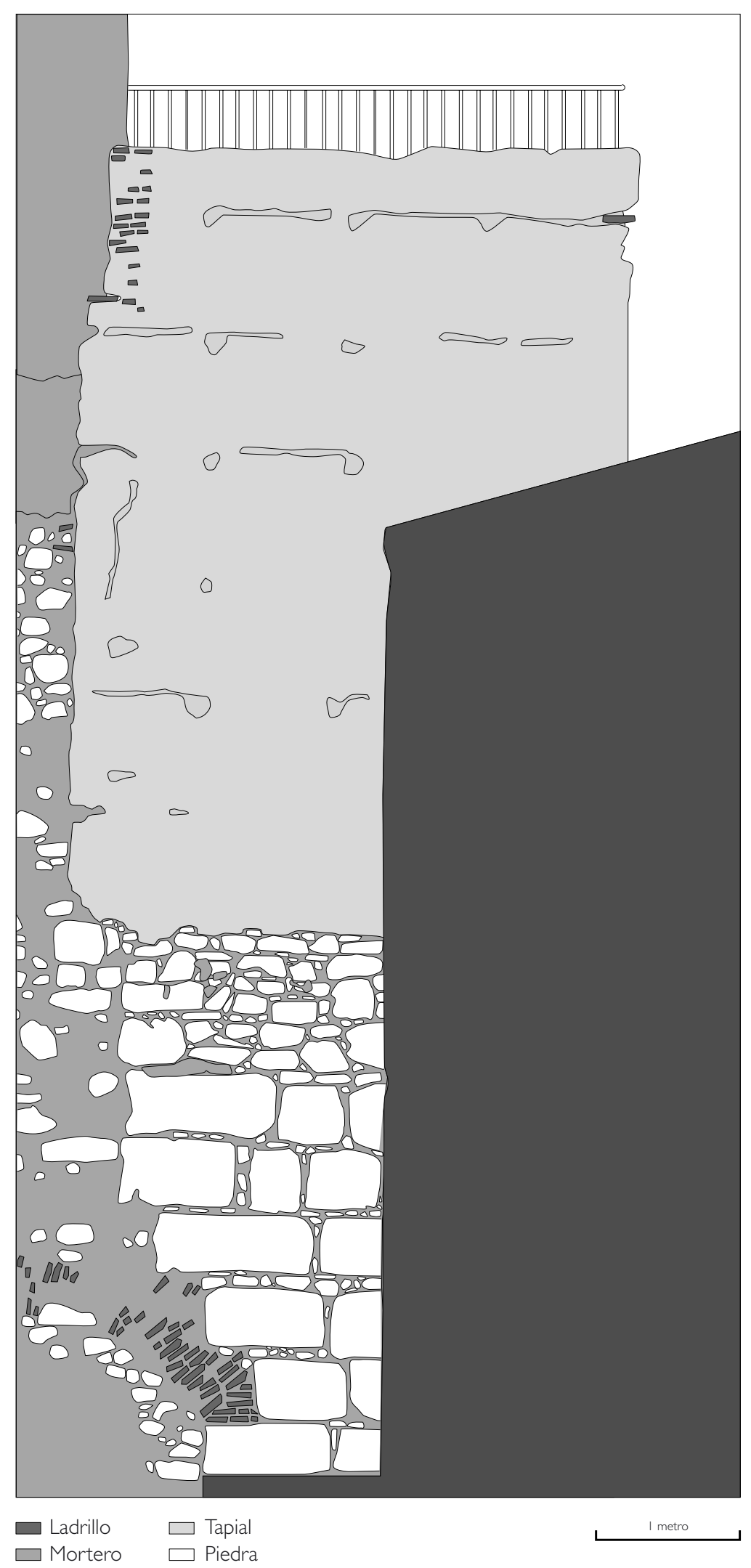

Lam. 6. Restitución fotogramétrica del frente $S$ de la torre oriental de la Calle comudillas. Escala gráfica 


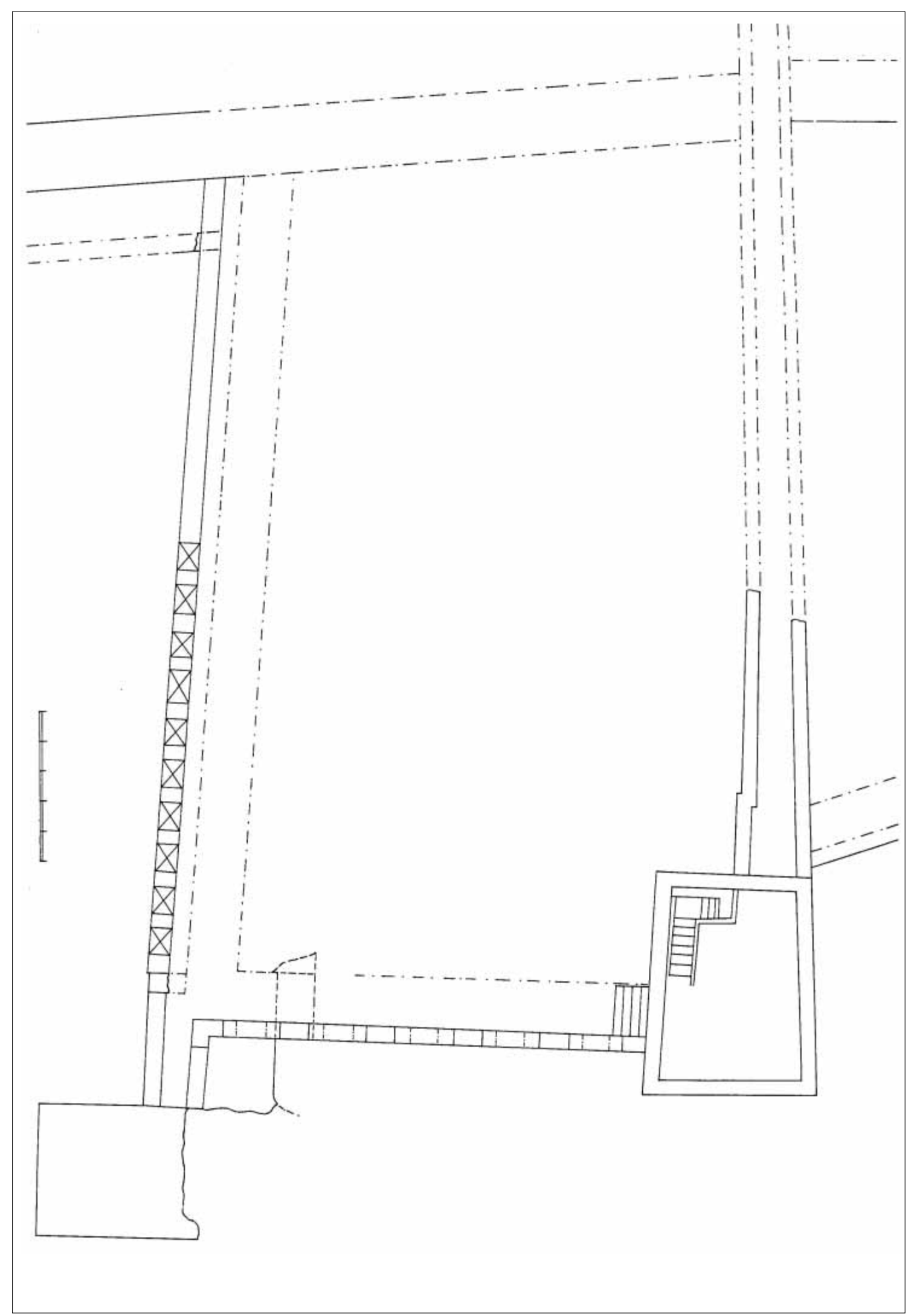

Lam. 7. Planta general del conjunto de la torre de los Pozos. Escala gráfica 


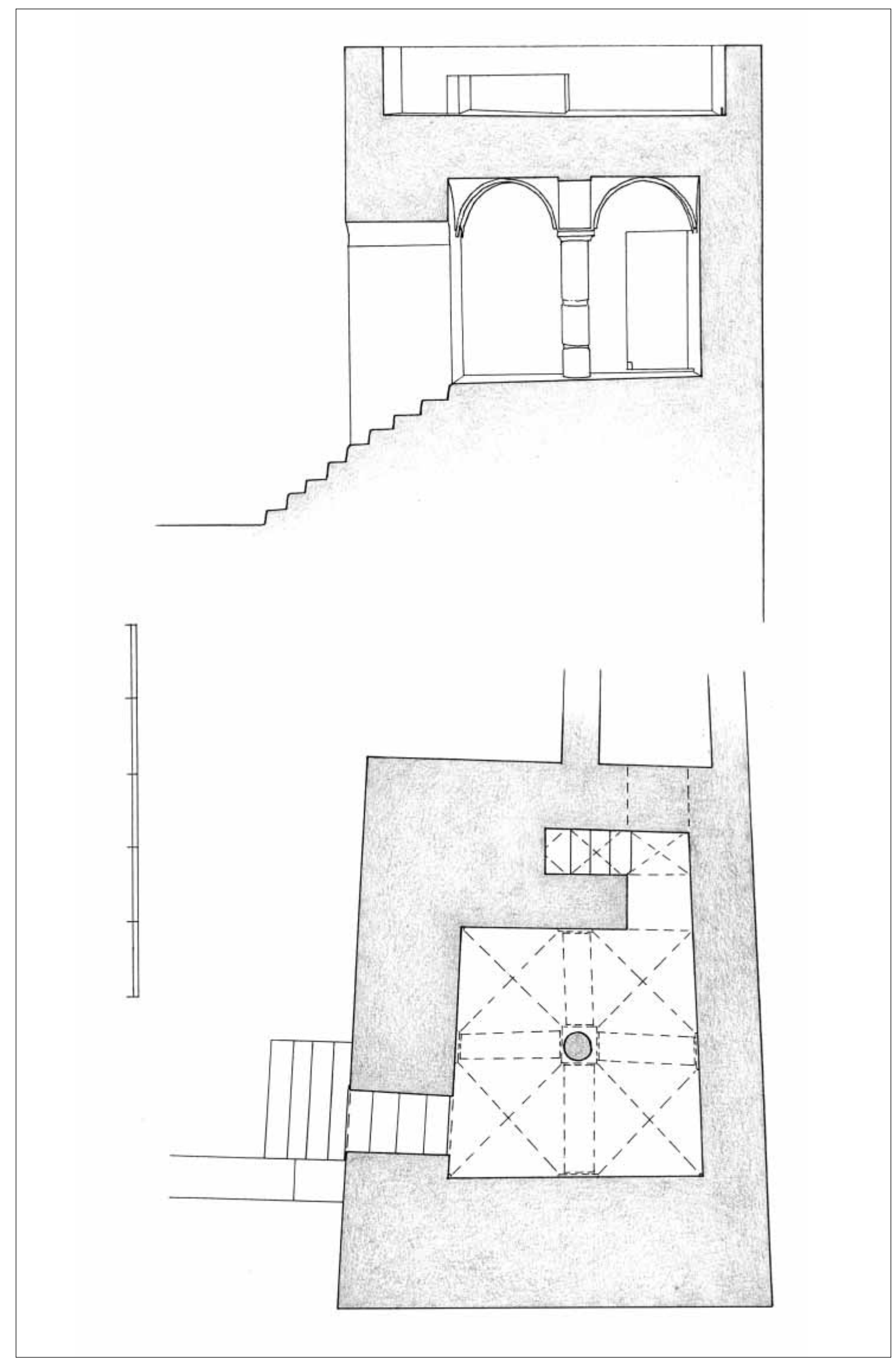

Lam. 8. Planta y sección de la cámara de la torre de los Pozos. Escala gráfica 


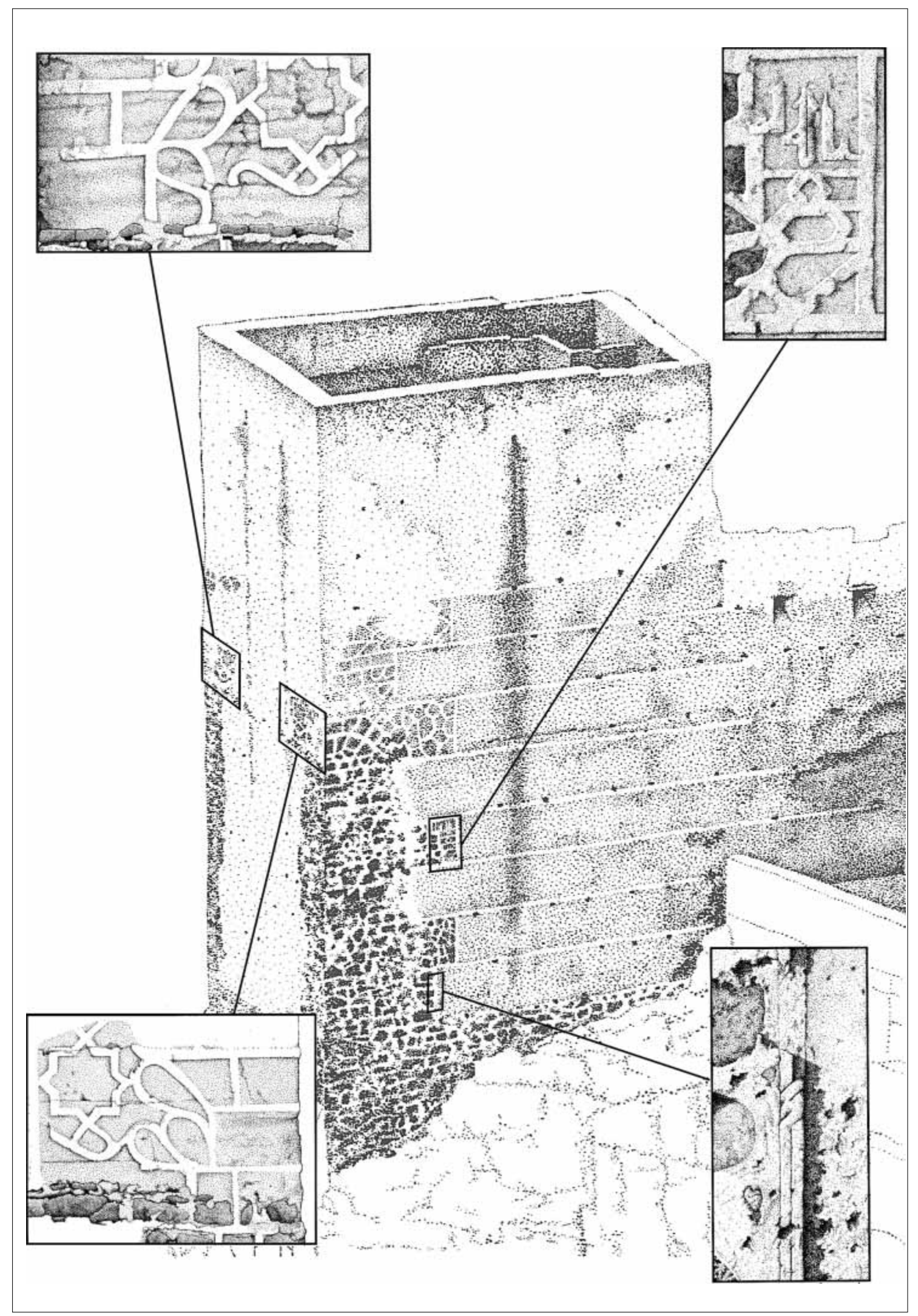

Lam. 9. Esquema de ubicación de elementos decorativos en la torre de los Pozos. Se representan en verdadera magnitud 